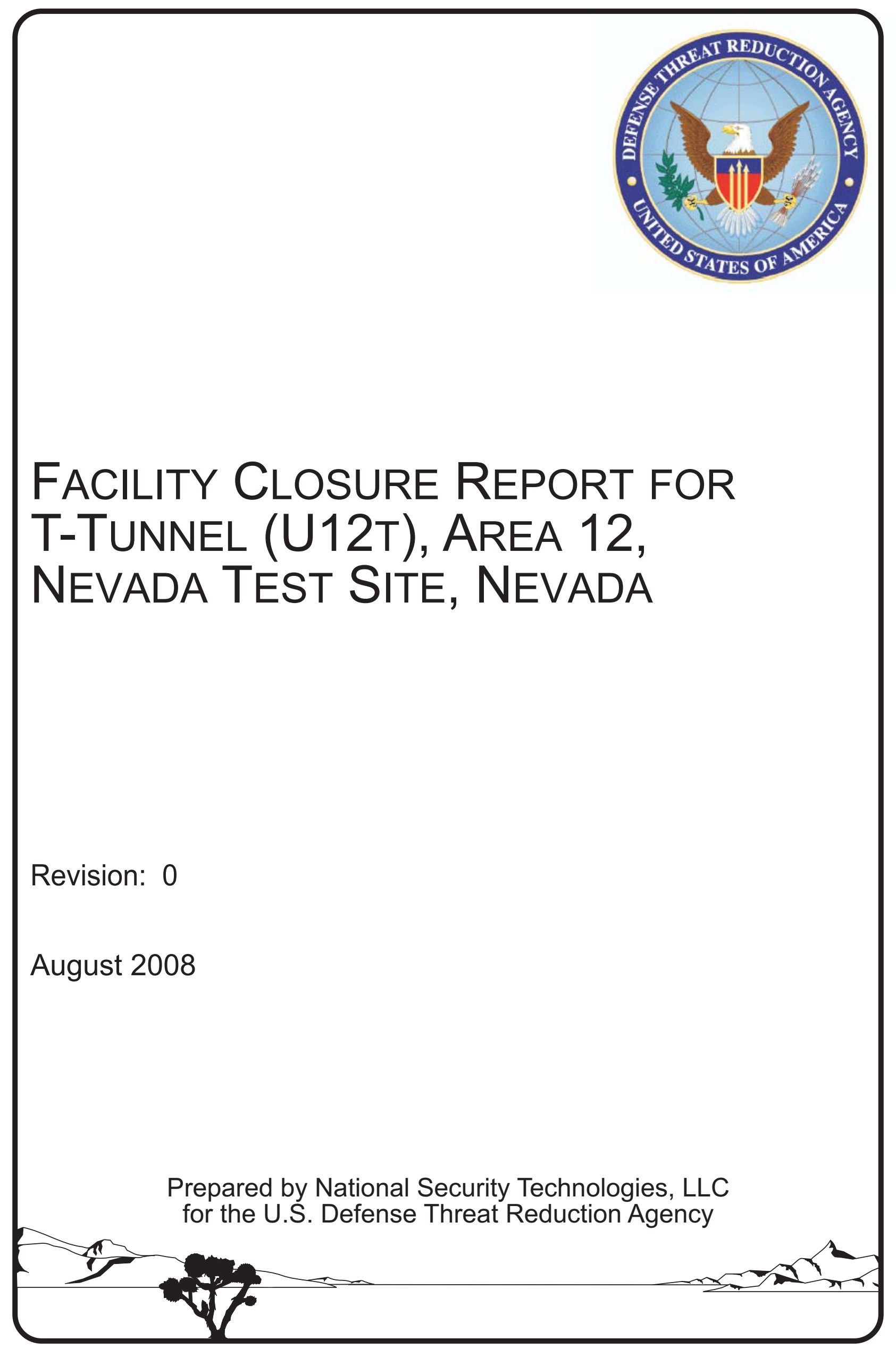





\title{
FACILITY CLOSURE REPORT FOR T-TUNNEL (U12T), AREA 12, NEVADA TEST SITE, NEVADA
}

\author{
Prepared by: \\ National Security Technologies, LLC
}

Las Vegas, Nevada

August 2008 
THIS PAGE INTENTIONALLY LEFT BLANK 


\section{FACILITY CLOSURE REPORT FOR T-TUNNEL (U12T), AREA 12, NEVADA TEST SITE, NEVADA}

Approved By:

Reed J. Poderis, Project Manager

Date:

National Security Technologies, LLC

Defense Threat Reduction Agency 
THIS PAGE INTENTIONALLY LEFT BLANK 


\section{TABLE OF CONTENTS}

ACRONYMS AND ABBREVIATIONS ........................................................................ vii

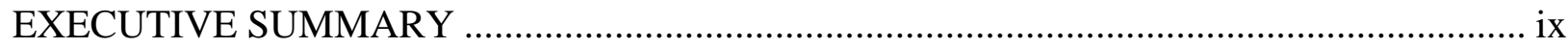

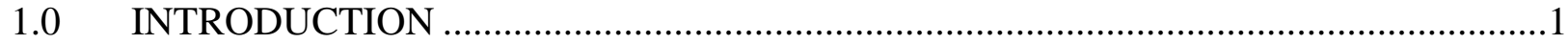

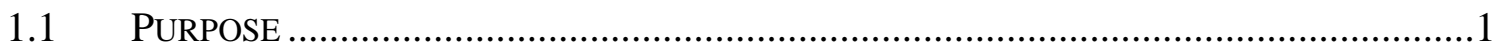

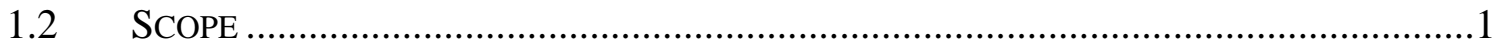

$1.3 \quad$ FACILITY CLOSURE REPORT CONTENTS ………………......................................

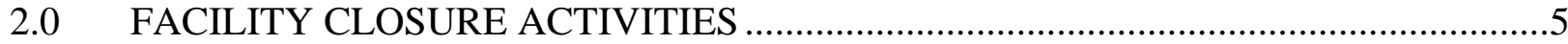

2.1 DESCRIPTION OF FACILITY ClOSURE ACTIVITIES ...................................................

2.1.1 Re-Lag Tunnel Walls and Roof ..................................................................

2.1.2 Waste Removal and Disposal ....................................................................

2.1.3 Sample and Drain Line Plugging and Sarcophagus.....................................6

2.1.4 Bulkhead Construction.............................................................................6

2.1.5 Vent Raise Grouting ................................................................................6

2.2 Deviations from the FACILITY Closure Plan AS APPROVED ..............................6

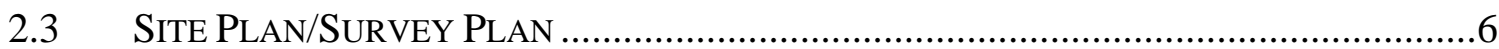

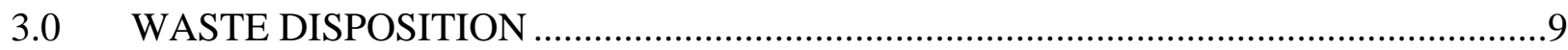

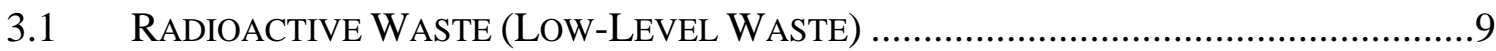

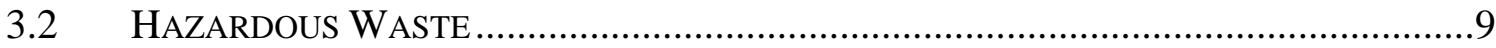

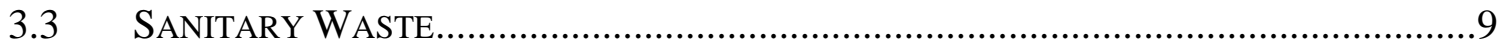

4.0 FACILITY CLOSURE VERIFICATION RESULTS ....................................................11

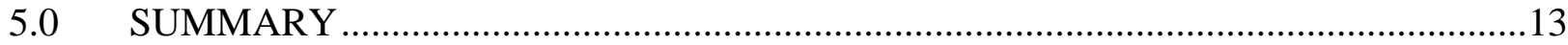

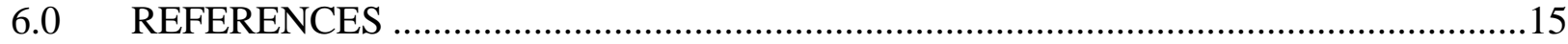

\section{FIGURES}

FIGURE 1. LOCATION OF T-TUNNEL …....................................................................................

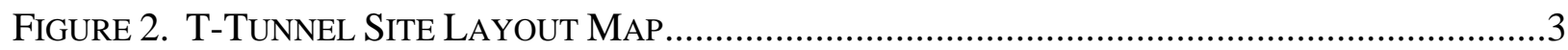

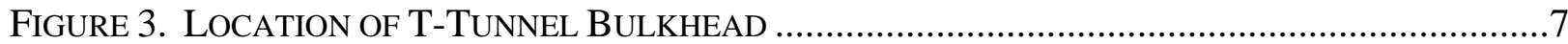




\section{APPENDICES}

Appendix A. As-Built Drawings

ApPEndiX B. Closure PhOTOGRAPHS

Appendix C. T-Tunnel Facility Closure Pressure Test Forms

Appendix D. FACility Closure Plan for N- AND T- Tunnels, Area 12, NevadA TEST SITE

Appendix E. Final Facility Closure Verification Site Visit Attendance Roster 


\section{ACRONYMS AND ABBREVIATIONS}

DTRA Defense Threat Reduction Agency

FCP Facility Closure Plan

FCR Facility Closure Report

GSD Gas Seal Door

GSP Gas Seal Plug

M\&OC Management and Operations Contractor

NDEP

Nevada Division of Environmental Protection

NNSA/NSO U.S. Department of Energy, National Nuclear Security Administration Nevada Site Office

NTS Nevada Test Site

NWET Nuclear Weapons Effects Test

UGTA Underground Test Area 
T-Tunnel Closure Report

Section: Acronyms \& Abbreviations

Revision: 0

Date: August 2008

THIS PAGE INTENTIONALLY LEFT BLANK 


\section{EXECUTIVE SUMMARY}

The U12t-Tunnel (T-Tunnel) is located in Area 12 of the Nevada Test Site. T-Tunnel is not listed in the Federal Facility Agreement and Consent Order. The closure of T-Tunnel was sponsored by the Defense Threat Reduction Agency (DTRA) and performed with the cooperation of the U.S. Department of Energy, National Nuclear Security Administration Nevada Site Office and the Nevada Division of Environmental Protection (NDEP).

The strategy for closure of this site is described in the NDEP-approved Facility Closure Plan for $N$ - and T-Tunnels Area 12, Nevada Test Site (Appendix D). Closure activities included:

- Removing and disposing of an oil-filled circuit breaker, fire extinguishers, and fluorescent light fixtures.

- $\quad$ Removing and entombing radiologically impacted vent lines within the T-Tunnel radiologically controlled area.

- Sealing the identified asbestos backboards in place as a hazard-reducing best management practice. The Facility Closure Plan (FCP) indicates that asbestos pipe insulation will be removed and disposed; however, there was no asbestos pipe insulation to remove.

- $\quad$ Sampling groundwater at the Gas Seal Door (GSD) from both the main and alternate water line, by Underground Test Area personnel.

- $\quad$ Plugging the water sample collection lines and the drain line that penetrated the GSD.

- Constructing a concrete sarcophagus on the portal side of the GSD to entomb all exposed sample collection lines and the drain line and to protect the lines from potential rock fall.

- Constructing a full-tunnel cross-section grout bulkhead to prevent access to the tunnel.

- Grouting the vent raise from the top of the bulkhead to the ground surface.

T-Tunnel was closed in accordance with the NDEP-approved FCP (Appendix D). 
T-Tunnel Closure Report

Section: Executive Summary

Revision: 0

Date: August 2008

THIS PAGE INTENTIONALLY LEFT BLANK 
This Facility Closure Report (FCR) has been prepared to document the actions taken to permanently close the remaining accessible areas of U12t-Tunnel (T-Tunnel) in Area 12 of the Nevada Test Site (NTS). The closure of T-Tunnel was a prerequisite to transfer facility ownership from the Defense Threat Reduction Agency (DTRA) to the U.S. Department of Energy, National Nuclear Security Administration Nevada Site Office (NNSA/NSO). Closure of the facility was accomplished with the cooperation and concurrence of both NNSA/NSO and the Nevada Division of Environmental Protection (NDEP).

\subsection{PURPOSE}

The purpose of this FCR is to document that the closure of T-Tunnel complied with the closure requirements specified in the Facility Closure Plan for $\mathrm{N}$ - and T-Tunnels Area 12, Nevada Test Site (Appendix D) and that the facility is ready for transfer to NNSA/NSO. The Facility Closure Plan (FCP) is provided in Appendix D.

T-Tunnel is located approximately 42 miles north of Mercury in Area 12 of the NTS (Figure 1). Between 1970 and 1987, T-Tunnel was used for six Nuclear Weapons Effects Tests (NWETs). The tunnel was excavated horizontally into the volcanic tuffs of Rainier Mesa. The T-Tunnel complex consists of a main access drift with two NWET containment structures, a Gas Seal Plug (GSP), and a Gas Seal Door (GSD) (Figure 2). The T-Tunnel complex was mothballed in 1993 to preserve the tunnel for resumption of testing, should it happen in the future, to stop the discharge of tunnel effluent, and to prevent unauthorized access. This was accomplished by sealing the main drift GSD.

\section{$1.2 \quad$ SCOPE}

The approved facility closure strategy for T-Tunnel was specified in the FCP (Appendix D). The FCP describes the containment structure (bulkhead) and procedure for closure of the accessible areas of the tunnel. Prior to closure, extensive water sampling was conducted by the Underground Test Area (UGTA) group. The UGTA water sampling activities were outside the scope of this FCP.

The implemented facility closure strategy consisted of the following activities:

- $\quad$ Removing and disposing of an oil-filled circuit breaker (reported in the FCP as a transformer), all fire extinguishers, and fluorescent light fixtures.

- $\quad$ Removing and entombing radiologically impacted vent lines within the T-Tunnel radiologically controlled area.

- $\quad$ Sealing the identified asbestos backboards in place as a hazard-reducing best management practice. The FCP indicates that asbestos pipe insulation will be removed and disposed; however, there was no asbestos pipe insulation to remove.

- $\quad$ Plugging the water sample collection lines and the drain line that penetrate the GSD. 


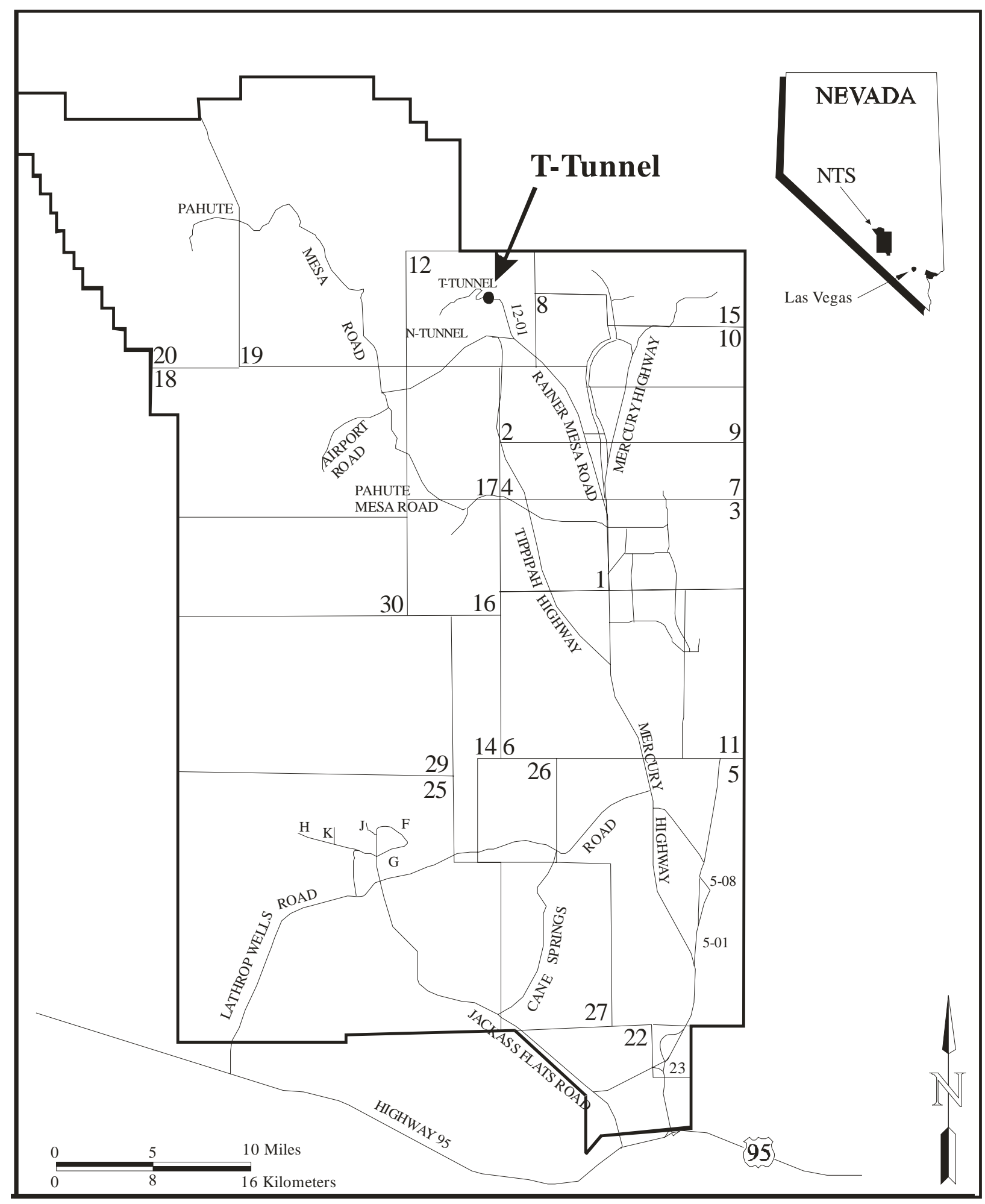

FigurE 1. LOCATION OF T-TUNNEL 
Date: August 2008

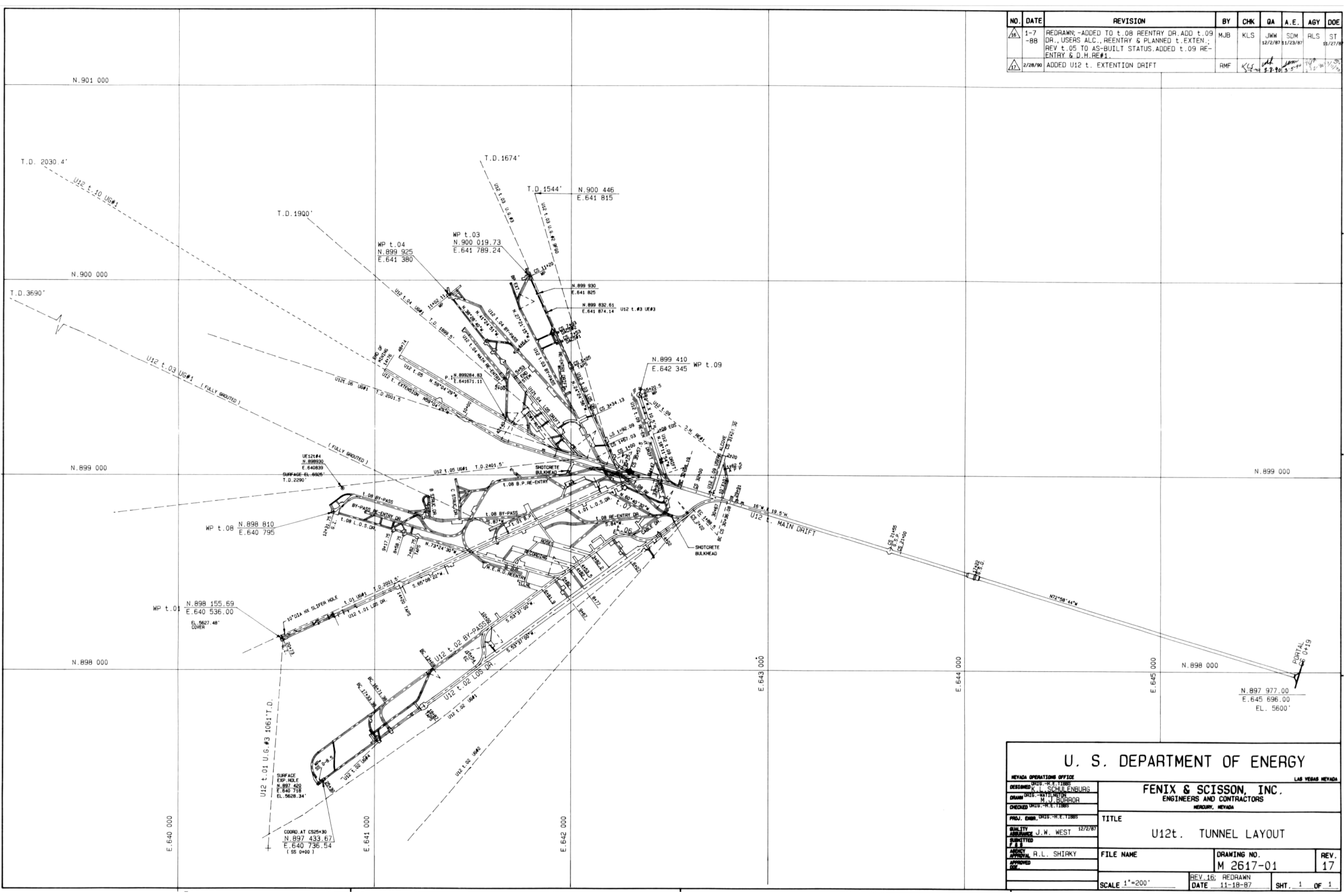

Figure 2. T-TunNEL Site LAyOUt MAP 
- $\quad$ Constructing a concrete sarcophagus on the portal side of the GSD to entomb all exposed sample collection lines and the drain line and to protect the lines from potential rock fall.

- Constructing a full-tunnel cross-section grout bulkhead to prevent access to the tunnel.

- $\quad$ Grouting the vent raise from the top of the bulkhead to the ground surface.

\subsection{FACILITy Closure Report CONTENTS}

This FCR is divided into the following sections:

- $\quad$ Section $1.0 \quad$ Introduction

- $\quad$ Section $2.0 \quad$ Facility Closure Activities

- $\quad$ Section $3.0 \quad$ Waste Disposition

- $\quad$ Section $4.0 \quad$ Facility Closure Verification Results

- $\quad$ Section $5.0 \quad$ Summary

- $\quad$ Section $6.0 \quad$ References

- Appendix A As-Built Drawings

- Appendix B Closure Photographs

- $\quad$ Appendix C T-Tunnel Facility Closure Pressure Test Forms

- $\quad$ Appendix D Facility Closure Plan for N- and T- Tunnels, Area 12, Nevada Test Site

- Appendix E Final Facility Closure Verification Site Visit Attendance Roster

This FCR was developed based upon the recommendations set forth in the following document:

- $\quad$ Facility Closure Plan for N- and T- Tunnels, Area 12, Nevada Test Site (Appendix D)

Construction quality was controlled by ensuring adherence to the design engineering specifications developed for the FCP (Appendix D). Verification of the design is documented in the construction “as-built” drawings included in Appendix A of this document. 


\subsection{FACILITY CLOSURE ACTIVITIES}

This section of the FCR details the specific activities involved in the closure of the T-Tunnel facility. As-built engineering drawings are provided in Appendix A. Photographs of the closure activities and completed work are provided in Appendix B.

\subsection{Description OF FACILITy Closure Activities}

Closure of the T-Tunnel facility was completed using the approved FCP (Appendix D). Prior to beginning closure activities, the following pre-field activities were completed:

- $\quad$ Preparation of National Environmental Policy Act documentation

- $\quad$ Preparation of the T-Tunnel Facility Closure Field Work Package

- $\quad$ Preparation of the T-Tunnel Facility Closure Task Site-Specific Health and Safety Plan

Facility closure activities were conducted from June 7, 2006, to May 24, 2007, and consisted of stabilizing the tunnel by re-lagging the tunnel roof and walls, removing and disposing of waste, grouting the sampling and drain lines that penetrate the GSD, constructing a grout sarcophagus at the GSD, relocating radiologically contaminated parts to within the tunnel's radiological material area, and constructing a fibercrete bulkhead near the portal entrance. The following sections detail the scope of actions implemented for the T-Tunnel facility closure. Daily reports of the closure progress are maintained in the Management and Operations Contractor (M\&OC) project files located at the NTS.

\subsubsection{Re-Lag Tunnel Walls and Roof}

Old lagging on the roof and walls of T-Tunnel had failed in numerous places and had allowed sloughing of the surrounding rock into portions of the tunnel. Lagging was replaced where needed to protect workers during closure activities.

\subsubsection{Waste Removal and Disposal}

Miscellaneous debris, construction-type waste materials, fluorescent light fixtures, and other items that are no longer useable were removed from the tunnel and disposed of appropriately. All waste was screened to verify that radiological contamination was less than the free-release limit established in the NV/YMP Radiological Control Manual (NNSA/NSO, 2004). Sanitary waste was transported to and disposed of in the Area 23 Sanitary Landfill at the NTS. A nonpolychlorinated biphenyl oil-filled circuit breaker was removed by the electricians and placed into their inventory, where it will either be re-used or disposed of along with other electrical equipment in accordance with their waste management plans.

Vent lines from the T-Tunnel roof up through the vent raise were radiologically contaminated. Because T-Tunnel is a radiologically controlled area, the vent lines were removed and placed within the tunnel, to be entombed within T-Tunnel behind the fibercrete bulkhead that was later constructed. The ends of the piping were covered as they were exposed, to prevent the spread of any radioactivity during removal and relocation activities. 


\subsubsection{Sample and Drain Line Plugging and Sarcophagus}

Water sample lines and a drain line were installed when the tunnel was mothballed in 1993. These 1- and 2-inch-diameter pipes facilitated the sampling of water impounded behind the GSP and the GSD. One set of sample lines, a main and an alternate, penetrated the GSD and the GSP to permit sampling of water from behind the GSP. A second set of sample lines, also a main and an alternate line, penetrated only the GSD to permit sampling of water from behind the GSD. A drain line was present between the two sets of sample lines. The UGTA group was separately tasked by NNSA/NSO to collect final water samples prior to the plugging and entombment of the sample lines.

After samples had been collected, the sample lines were then plugged by pressure grouting and capping the lines. All lines were then entombed in a grout sarcophagus to prevent damage from potential rock fall. The sequence of events to plug sample lines and construct the sarcophagus is depicted in photographs provided in Appendix B.

\subsubsection{Bulkhead Construction}

A grout bulkhead was constructed near the main drift portal, underneath the vent raise, to prevent access to the tunnel (see Figure 3 or Appendix A for exact location). The bulkhead form was constructed by tack welding 1/4-inch, 18-gauge expanded metal sheets to 3-5/8-inch, 16-gauge steel studs on 16-inch horizontal and 24 -inch vertical centers. The expanded metal frame was then sprayed with fibercrete to a thickness of 6 inches. Grout was poured into the vent raise to create the bulkhead. Access to the tunnel is thereby blocked by the newly constructed bulkhead. Access to the bulkhead is controlled by a locked portal gate that has been left in place because of its historical significance. Photographs of bulkhead construction are provided in Appendix B.

\subsubsection{Vent Raise Grouting}

The vent raise was filled with grout from the top of the bulkhead to 10 feet below ground surface. Vertical vent piping that was still present within the vent raise was also filled with grout. A 10-foot-thick concrete cap was placed from the top of the grout plug, to the ground surface.

\subsection{Deviations from the Facility Closure Plan as Approved}

There were three deviations from the FCP: (1) The M\&OC Environmental Compliance staff determined that it was safer not to disturb the asbestos backboards used to support the electrical panels; therefore, these panels were left in place. (2) Asbestos insulation was not removed from water lines because there was no asbestos insulation on the water lines. (3) The bulkhead was constructed of grout rather than fibercrete.

\subsection{Site Plan/Survey Plan}

The final engineering “as-built” drawings of the bulkheads for the T-Tunnel closure are provided in Appendix A. 


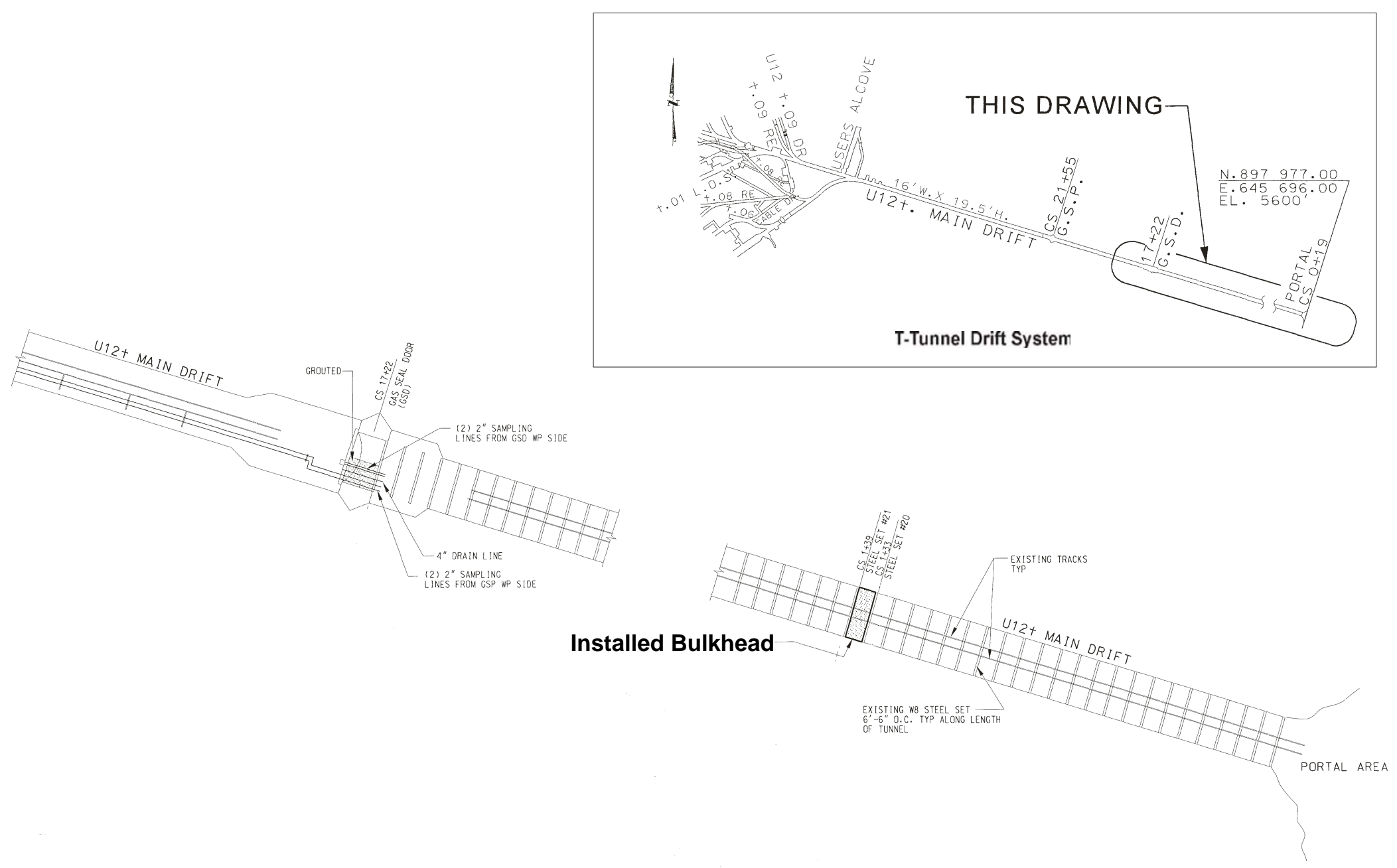

FiguRE 3. LOCATION OF T-TUNNEL BULKHEAD 
T-Tunnel Closure Report

Section: Closure Activities

Revision: 0

Date: August 2008

THIS PAGE INTENTIONALLY LEFT BLANK 


\subsection{WASTE DISPOSITION}

Waste generated from T-Tunnel facility closure activities included non-hazardous material from miscellaneous cleanup and construction activities. All waste was surveyed and managed in accordance with federal and state regulations, U.S. Department of Energy orders, and contractor company procedures. All waste was containerized for proper disposal in the appropriate disposal landfill.

\subsection{RADIOACTIVE WASTE (LOW-LEVEL WASTE)}

No low-level waste was generated or disposed of during T-Tunnel facility closure activities.

\subsection{HAZARDOUS WASTE}

No hazardous waste was generated or disposed of during T-Tunnel facility closure activities.

\subsection{SANITARY WASTE}

Non-hazardous waste, such as sanitary trash and personal protective equipment was disposed of in the NTS Area 23 Sanitary Landfill. Miscellaneous construction debris was disposed of in the NTS Area 9 U10c Sanitary Landfill. 
T-Tunnel Closure Report

Section: Waste Disposition

Revision: 0

Date: August 2008

THIS PAGE INTENTIONALLY LEFT BLANK 


\subsection{FACILITY CLOSURE VERIFICATION RESULTS}

Site closure was verified by the following activities:

- $\quad$ The main drift bulkhead design and construction were documented through engineering plans and verified by “as-built” drawings, which are included in Appendix A.

- $\quad$ A site walk-down by DTRA; Stoller-Navarro Joint Venture; National Security Technologies, LLC; NNSA/NSO; and NDEP representatives was performed on February 8, 2007. The consensus of the group was that actions necessary to close the T-Tunnel facility had been adequately completed and the fibercrete bulkhead could be installed. The attendance roster is included in Appendix E. 
T-Tunnel Closure Report

Section: Closure Verification

Revision: 0

Date: August 2008

THIS PAGE INTENTIONALLY LEFT BLANK 


\subsection{SUMMARY}

Closure of the T-Tunnel facility was accomplished by completing the following tasks:

- $\quad$ The tunnel walls and roof were re-lagged where needed to permit safe entry and work within T-Tunnel.

- Miscellaneous debris and old equipment was removed and disposed of, including an oil-filled circuit breaker (reported in the FCP as a transformer), all fire extinguishers, and fluorescent light fixtures.

- Radiologically impacted vent lines were removed and entombed within the T-Tunnel radiologically controlled area.

- $\quad$ The UGTA group was supported during final water sample collection.

- $\quad$ Sample and drain lines were pressure grouted and capped.

- A grout sarcophagus was constructed to entomb all exposed sample collection lines and the drain line and to protect the lines from potential rock fall.

- A full-tunnel cross-section grout bulkhead was constructed to prevent access to the tunnel.

- $\quad$ The vent raise, including vents still located within the vent raise, was filled with grout from the top of the bulkhead to 10 feet below ground surface. A concrete pad was then poured from the top of the grout to the ground surface.

The T-Tunnel facility, including the existing portal gate and remaining structures, has been declared historically significant and as such will remain in place. 
T-Tunnel Closure Report

Section: Conclusions/Recommendations

Revision: 0

Date: August 2008

THIS PAGE INTENTIONALLY LEFT BLANK 


\subsection{REFERENCES}

NNSA/NSO, see U.S. Department of Energy, National Nuclear Security Administration Nevada Site Office.

U.S. Department of Energy, National Nuclear Security Administration Nevada Site Office, 2004. NV/YMP Radiological Control Manual. DOE/NV/11718--079-Rev 5. Las Vegas, NV. 
T-Tunnel Closure Report

Section: Conclusions/Recommendations

Revision: 0

Date: August 2008

THIS PAGE INTENTIONALLY LEFT BLANK 
T-Tunnel Closure Report

Section: Appendix A

Revision: 0

Date: August 2008

\section{APPENDIX A}

\section{AS-BUILT DRAWINGS}


T-Tunnel Closure Report

Section: Appendix A

Revision: 0

Date: August 2008

THIS PAGE INTENTIONALLY LEFT BLANK 


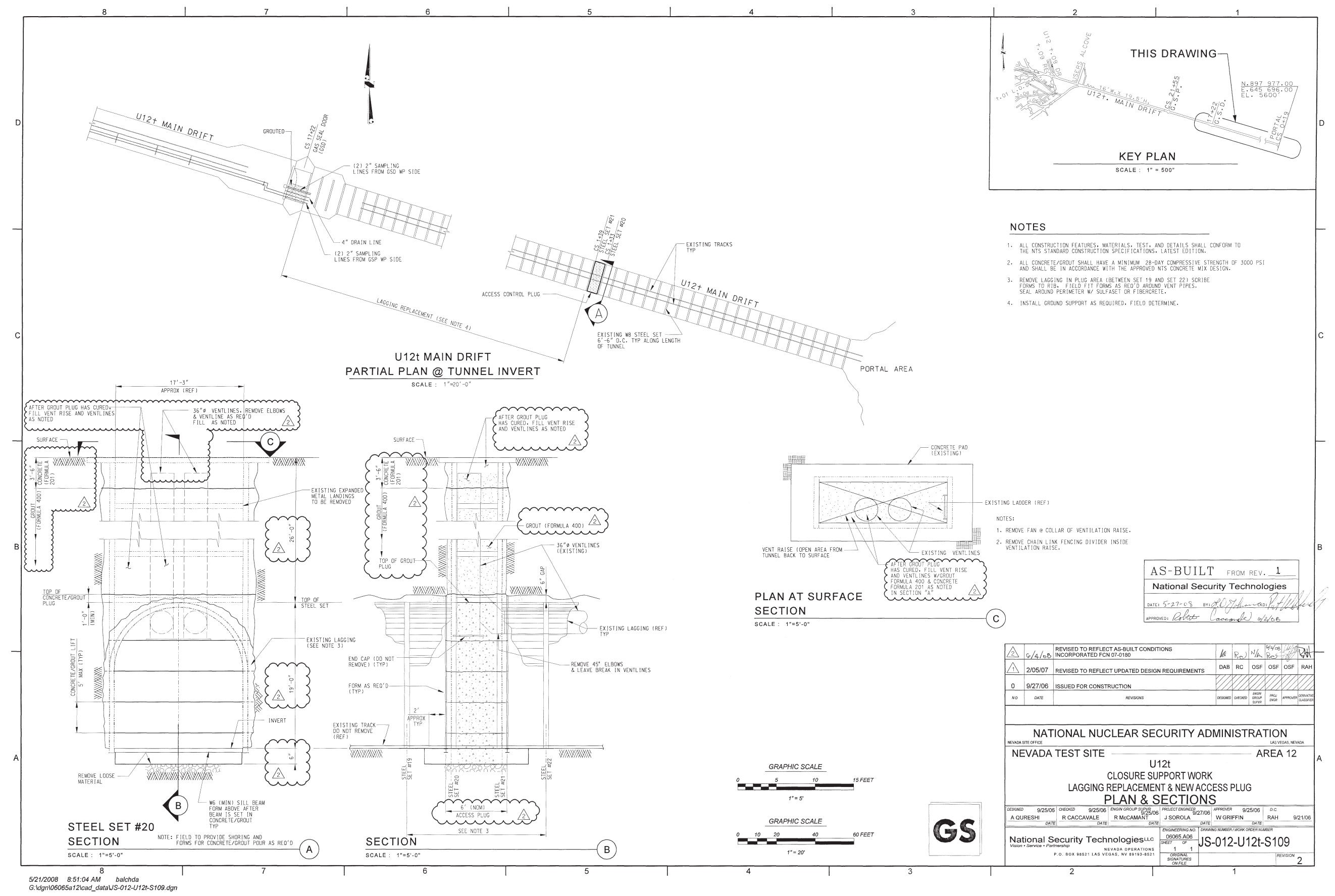


T-Tunnel Closure Repor
Section: Appendix A

Section: Appendix

Revision: 0 : 2008

THIS PAGE INTENTIONALLY LEFT BLANK 
T-Tunnel Closure Report

Section: Appendix B

Revision: 0

Date: August 2008

\section{APPENDIX B}

\section{CLOSURE PHOTOGRAPHS}


T-Tunnel Closure Report

Section: Appendix B

Revision: 0

Date: August 2008

THIS PAGE INTENTIONALLY LEFT BLANK 


\section{PHOTOGRAPH LOG}

\begin{tabular}{|c|c|c|}
\hline $\begin{array}{c}\text { Photo } \\
\text { Number }\end{array}$ & Date & Description \\
\hline 1 & $01 / 26 / 2006$ & $\begin{array}{l}\text { View inside T-Tunnel indicating poor condition of existing lagging and rock } \\
\text { falls within tunnel }\end{array}$ \\
\hline 2 & 09/12/2006 & View of area where lagging was replaced \\
\hline 3 & 01/26/2006 & $\begin{array}{l}\text { Sample and drain lines on portal side of Gas Sample Door (GSD), to the right } \\
\text { side of the portal. Lines penetrate GSD on left side. Piping from left side is } \\
\text { visible in lower left corner of photo. }\end{array}$ \\
\hline 4 & 01/26/2006 & $\begin{array}{l}\text { Sample and drain lines penetrating GSD on left side of GSD. Gas Seal Plug } \\
\text { (GSP) main and alternate sample lines on left, GSD sample lines on right, and } \\
\text { drain line in middle }\end{array}$ \\
\hline 5 & $01 / 26 / 2006$ & GSP sample lines and drain line \\
\hline 6 & $01 / 26 / 2006$ & Drain line and GSD sample lines \\
\hline 7 & $10 / 18 / 2006$ & $\begin{array}{l}\text { Pressure-testing the sample lines to verify they are airtight to be filled under } \\
\text { pressure with grout. Extraneous piping to the right side of the tunnel has been } \\
\text { disconnected. Remaining piping has been extended upward to permit pressure } \\
\text { grouting. }\end{array}$ \\
\hline 8 & $10 / 25 / 2006$ & Area around sample and drain lines sandbagged for sarcophagus concrete pour \\
\hline 9 & $10 / 25 / 2006$ & Sample and drain lines sticking up out of partial sarcophagus \\
\hline 10 & $01 / 10 / 2007$ & Sample and drain lines prepared for pressurized grouting \\
\hline 11 & $01 / 10 / 2007$ & Grout pumps (right side of photo) used to fill sample and drain lines \\
\hline 12 & $01 / 10 / 2007$ & GSP sample lines, grout-filled \\
\hline 13 & $01 / 10 / 2007$ & GSP sample lines, capped \\
\hline 14 & $01 / 10 / 2007$ & GSD sample lines, grout-filled \\
\hline 15 & $01 / 10 / 2007$ & GSD sample lines, capped \\
\hline 16 & $01 / 11 / 2007$ & Form erected for sarcophagus completion \\
\hline 17 & $01 / 11 / 2007$ & Completed sarcophagus \\
\hline 18 & 02/21/2007 & $\begin{array}{l}\text { Vent piping from top of vent raise (at right) being covered } \\
\text { to prevent spread of radioactive contamination }\end{array}$ \\
\hline 19 & 02/21/2007 & Covered vent raise piping being removed \\
\hline 20 & 02/21/2007 & Additional vent raise piping being covered and removed \\
\hline 21 & $02 / 21 / 2007$ & $\begin{array}{l}\text { Removed vent raise piping in Radioactive Material Area } \\
\text { pending transfer to tunnel }\end{array}$ \\
\hline 22 & $02 / 21 / 2007$ & Top of vent raise after vent piping has been removed \\
\hline 23 & $02 / 26 / 2007$ & Bottom of vent raise piping, inside T-Tunnel \\
\hline 24 & $02 / 28 / 2007$ & $\begin{array}{l}\text { Vent raise piping disconnected from tunnel vent piping and } \\
\text { covered to prevent spread of radioactive contamination }\end{array}$ \\
\hline 25 & $02 / 28 / 2007$ & View up vent raise from within T-Tunnel \\
\hline 26 & 03/01/2007 & Base framing for bulkhead, beneath the vent raise \\
\hline 27 & 03/01/2007 & Hauling in concrete for the bulkhead base \\
\hline 28 & 03/01/2007 & Bulkhead concrete base \\
\hline 29 & 03/06/2007 & Bulkhead framing \\
\hline
\end{tabular}




\section{PHOTOGRAPH LOG (continued)}

\begin{tabular}{|c|c|l||}
\hline $\begin{array}{c}\text { Photo } \\
\text { Number }\end{array}$ & \multicolumn{1}{|c||}{ Date } & \multicolumn{1}{c||}{ Description } \\
\hline \hline 30 & $03 / 13 / 2007$ & Bulkhead framing \\
\hline 31 & $03 / 15 / 2007$ & Bulkhead framing \\
\hline 32 & $03 / 15 / 2007$ & Bulkhead framing with metal sheeting \\
\hline 33 & $03 / 15 / 2007$ & Bulkhead frame with metal sheeting against tunnel wall \\
\hline 34 & $03 / 21 / 2007$ & Bulkhead framing and sheeting, view into tunnel \\
\hline 35 & $03 / 22 / 2007$ & Bulkhead framing and sheeting, view out of tunnel \\
\hline 36 & $04 / 09 / 2007$ & Bulkhead with fibercrete application in process \\
\hline 37 & $04 / 09 / 2007$ & Bulkhead with fibercrete application in process \\
\hline 38 & $05 / 08 / 2007$ & Bulkhead with fibercrete application in process \\
\hline 39 & $05 / 09 / 2007$ & Bulkhead with fibercrete application in process \\
\hline 40 & $06 / 14 / 2007$ & Completed bulkhead \\
\hline 41 & $06 / 14 / 2007$ & Underground Radioactive Material sign affixed to bulkhead \\
\hline 42 & $05 / 14 / 2007$ & Grout pour into vent raise \\
\hline 43 & $05 / 17 / 2007$ & Partially grout-filled vent raise \\
\hline 44 & $05 / 17 / 2007$ & Partially grout-filled vent raise \\
\hline 45 & $05 / 24 / 2007$ & Vent raise almost filled with concrete \\
\hline 46 & $05 / 24 / 2007$ & Vent raise completely filled and finished \\
\hline
\end{tabular}




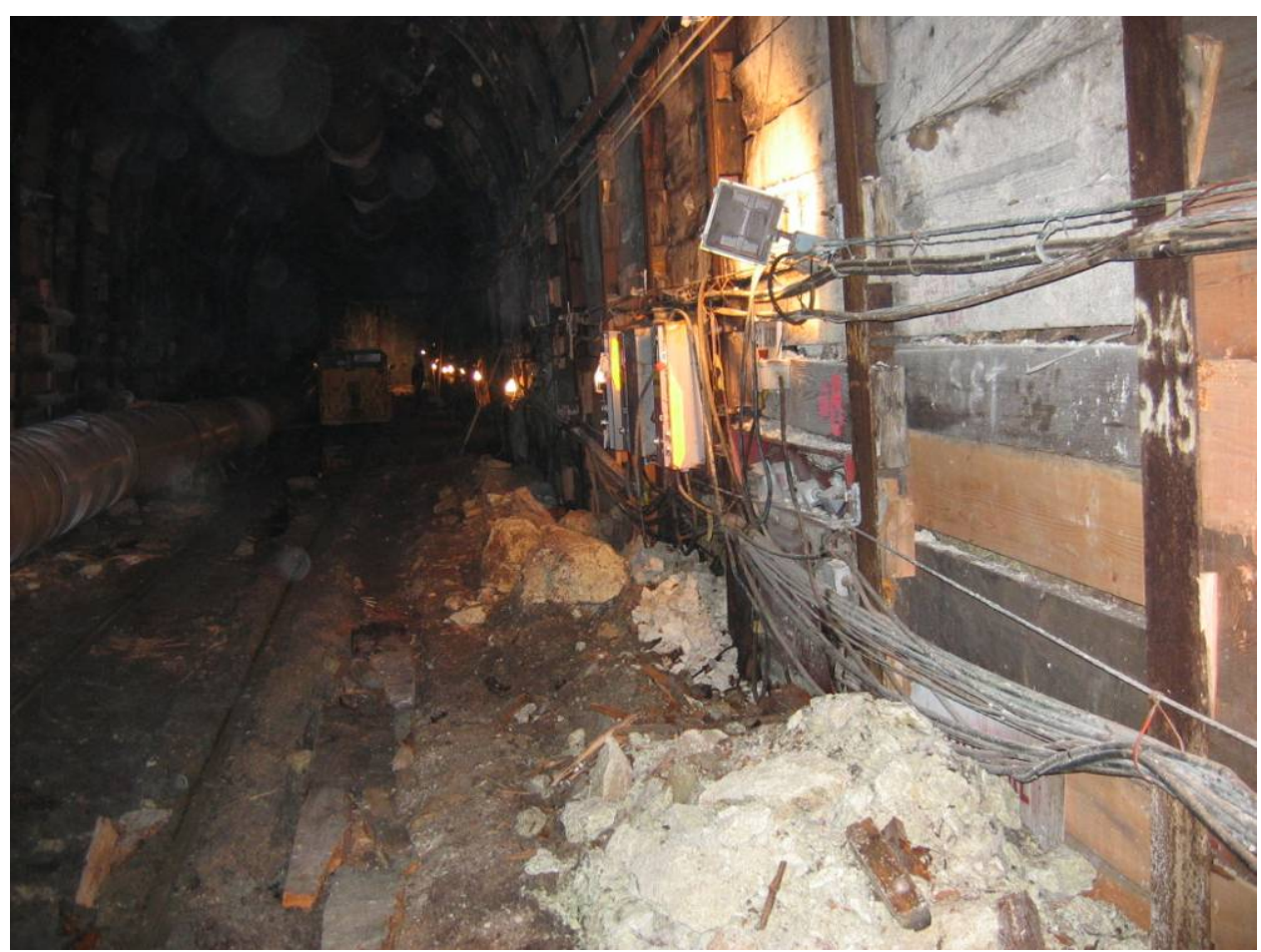

Photograph 1: View inside T-Tunnel indicating poor condition of existing lagging and rock falls within tunnel, 01/26/2006

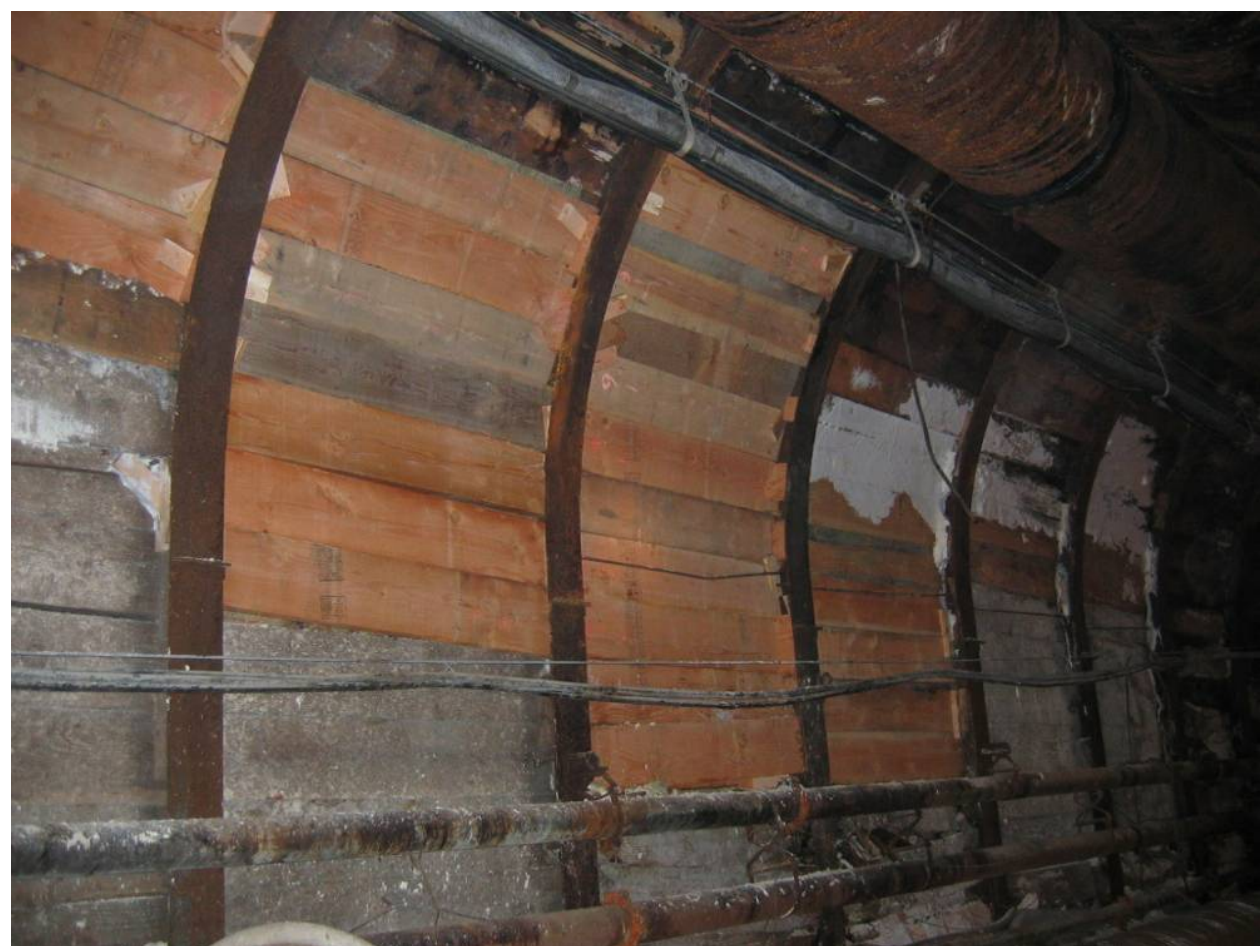

Photograph 2: View of area where lagging was replaced, 09/12/2006 


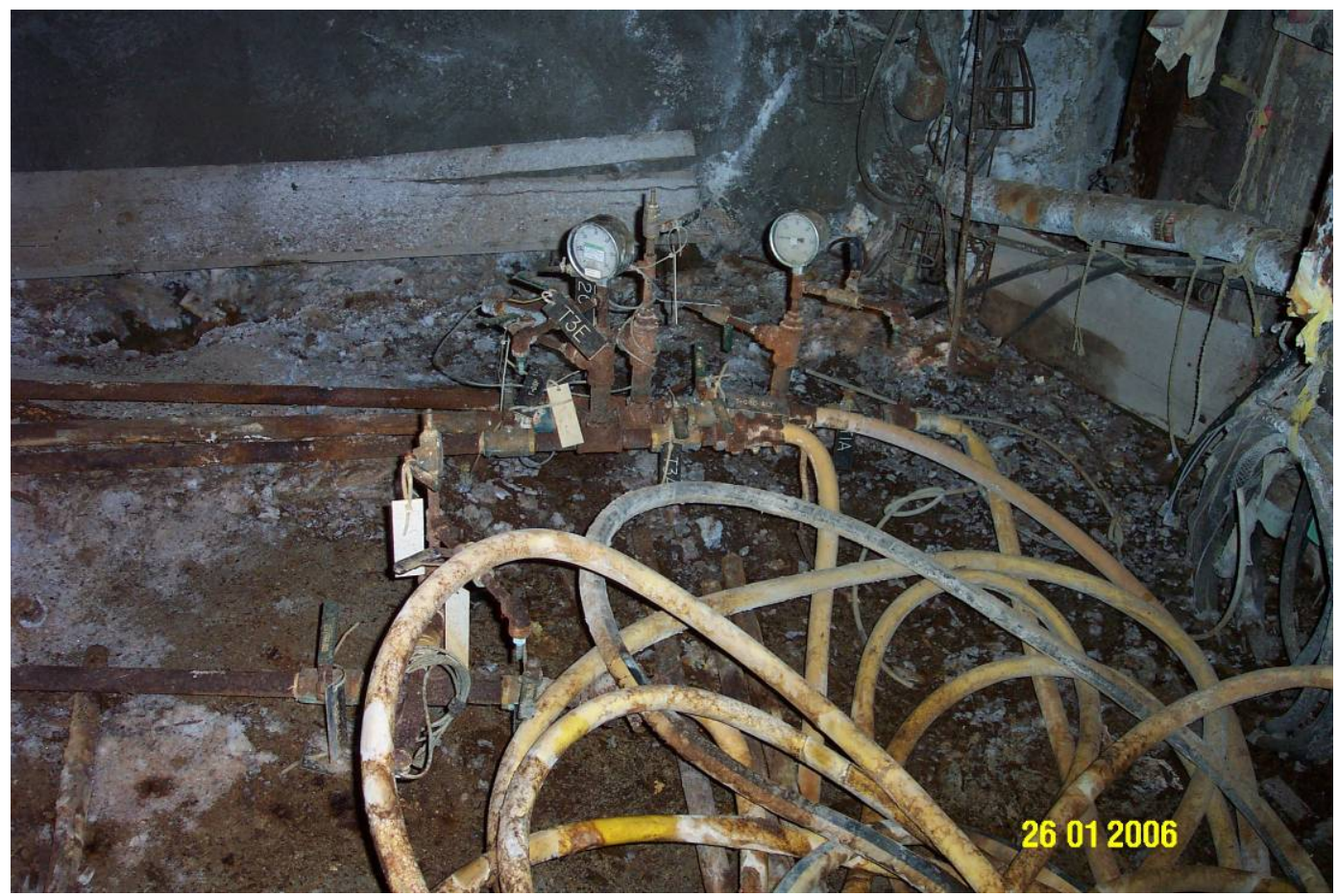

Photograph 3: Sample and drain lines on portal side of Gas Sample Door (GSD), to the right side of the portal. Lines penetrate GSD on left side. Piping from left side is visible in lower left corner of photo. 01/26/2006

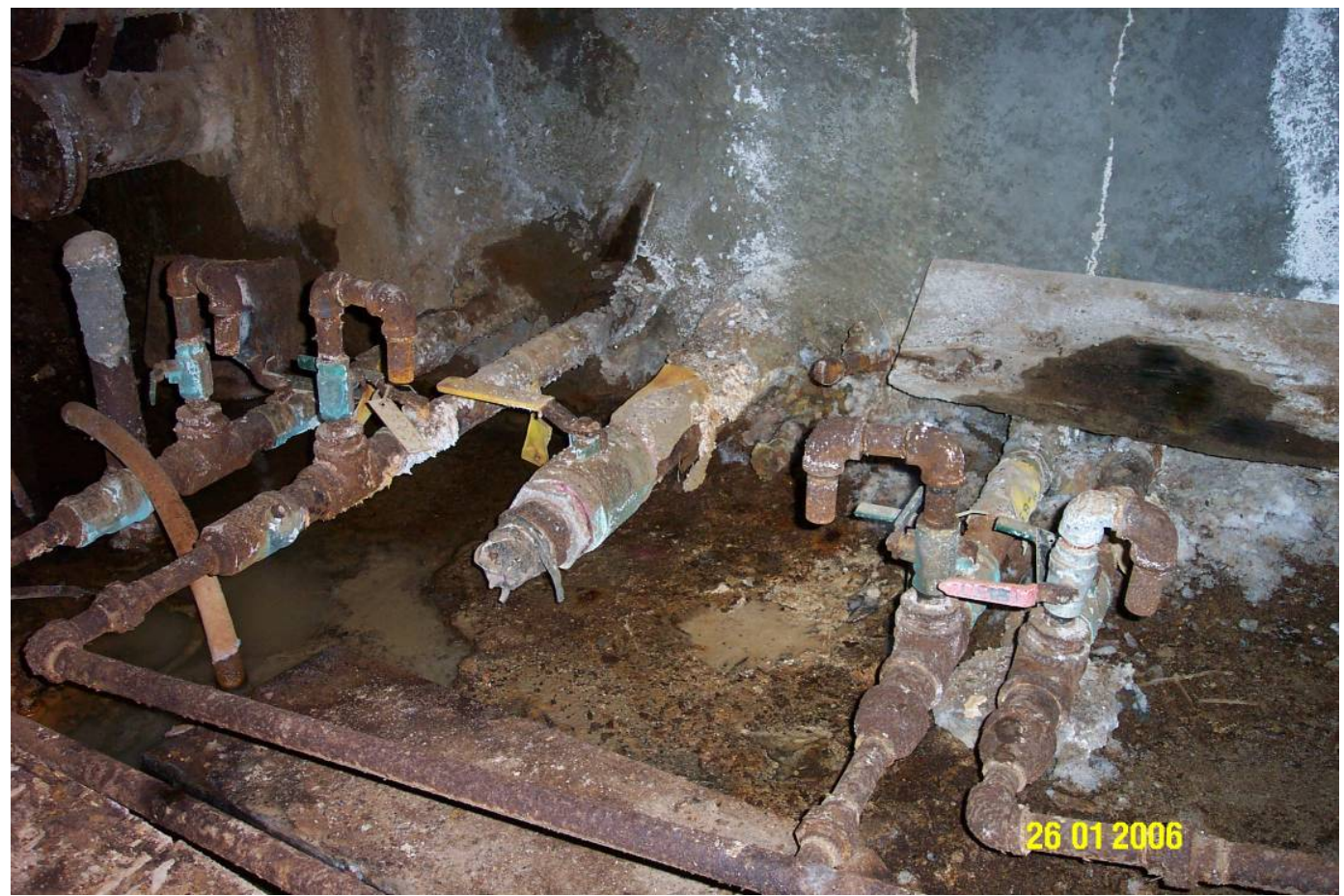

Photograph 4: Sample and drain lines penetrating GSD on left side of GSD.

Gas Seal Plug (GSP) main and alternate sample lines on left, GSD sample lines on right, and drain line in middle, 01/26/2006 


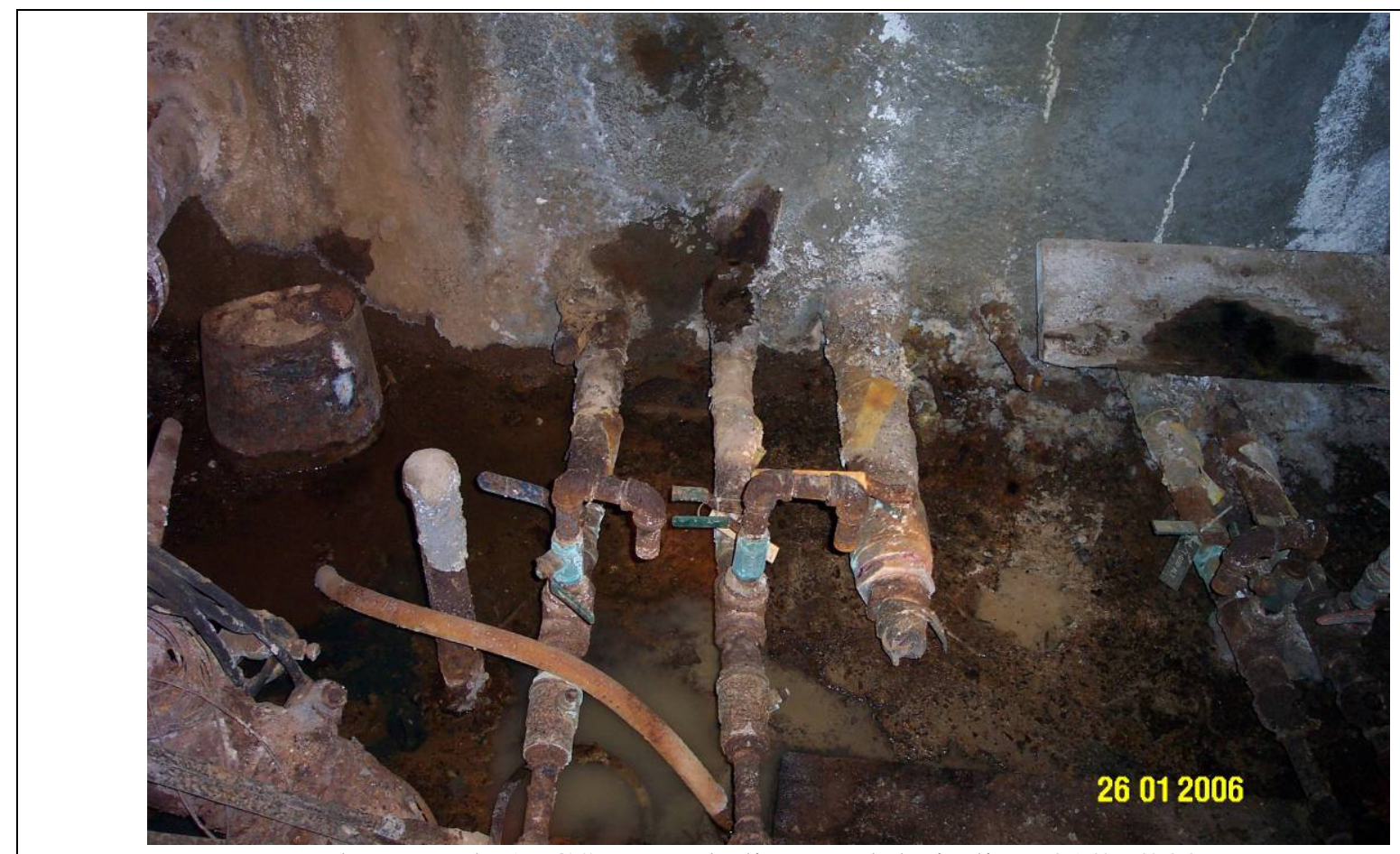

Photograph 5: GSP sample lines and drain line, 01/26/2006

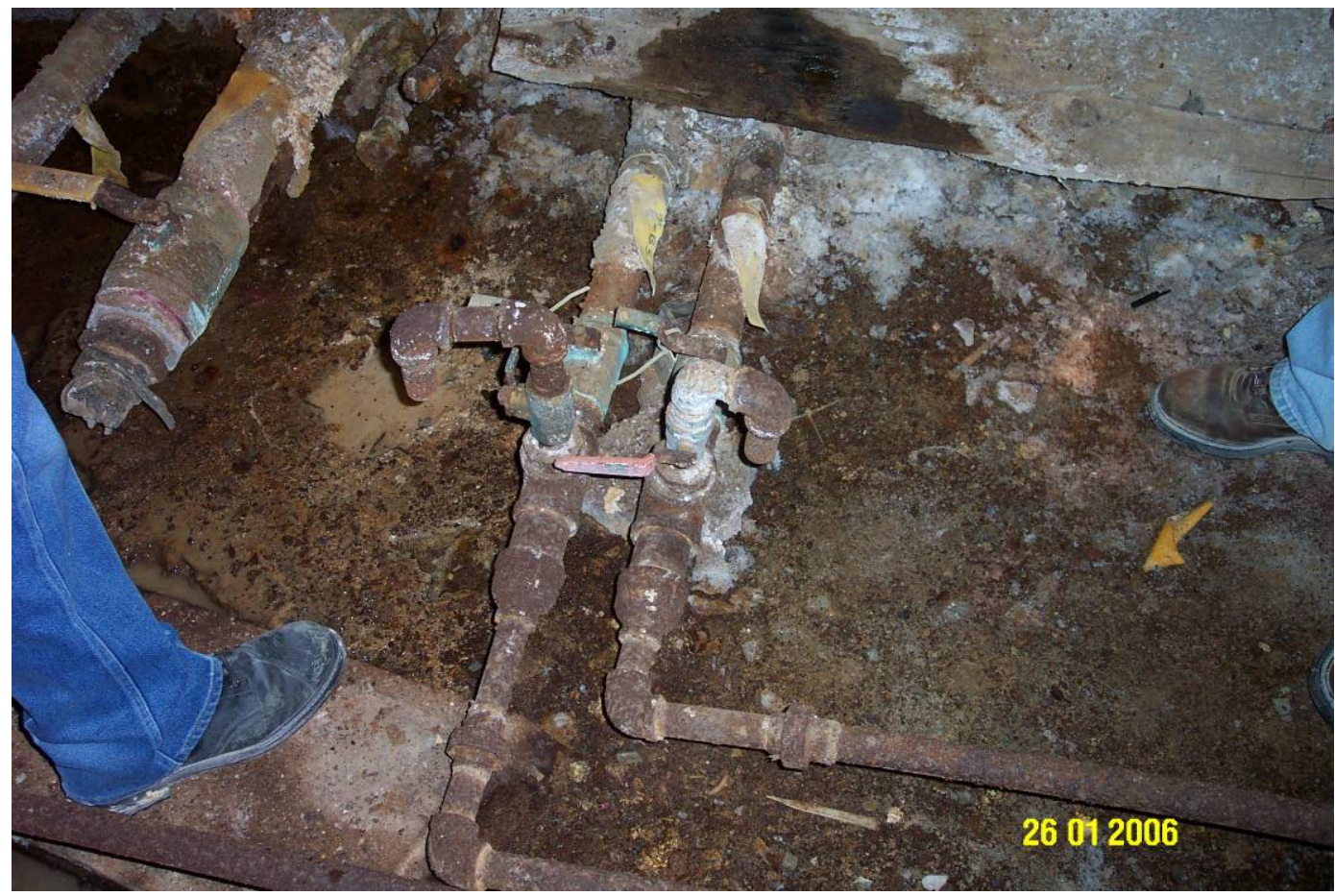

Photograph 6: Drain line and GSD sample lines, 01/26/2006 


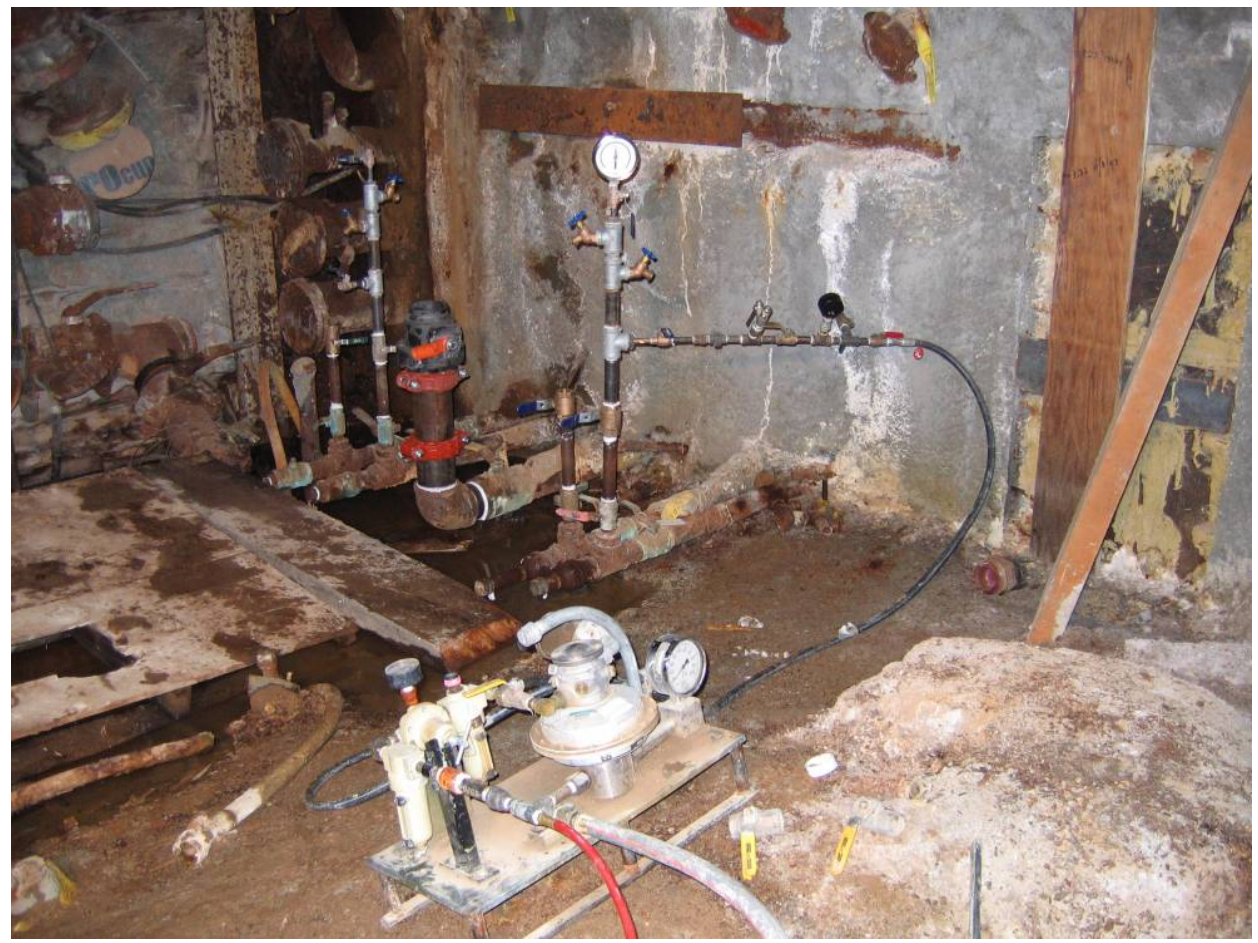

Photograph 7: Pressure-testing the sample lines to verify they are airtight to be filled under pressure with grout. Extraneous piping to the right side of the tunnel has been disconnected.

Remaining piping has been extended upward to permit pressure grouting. 10/18/2006

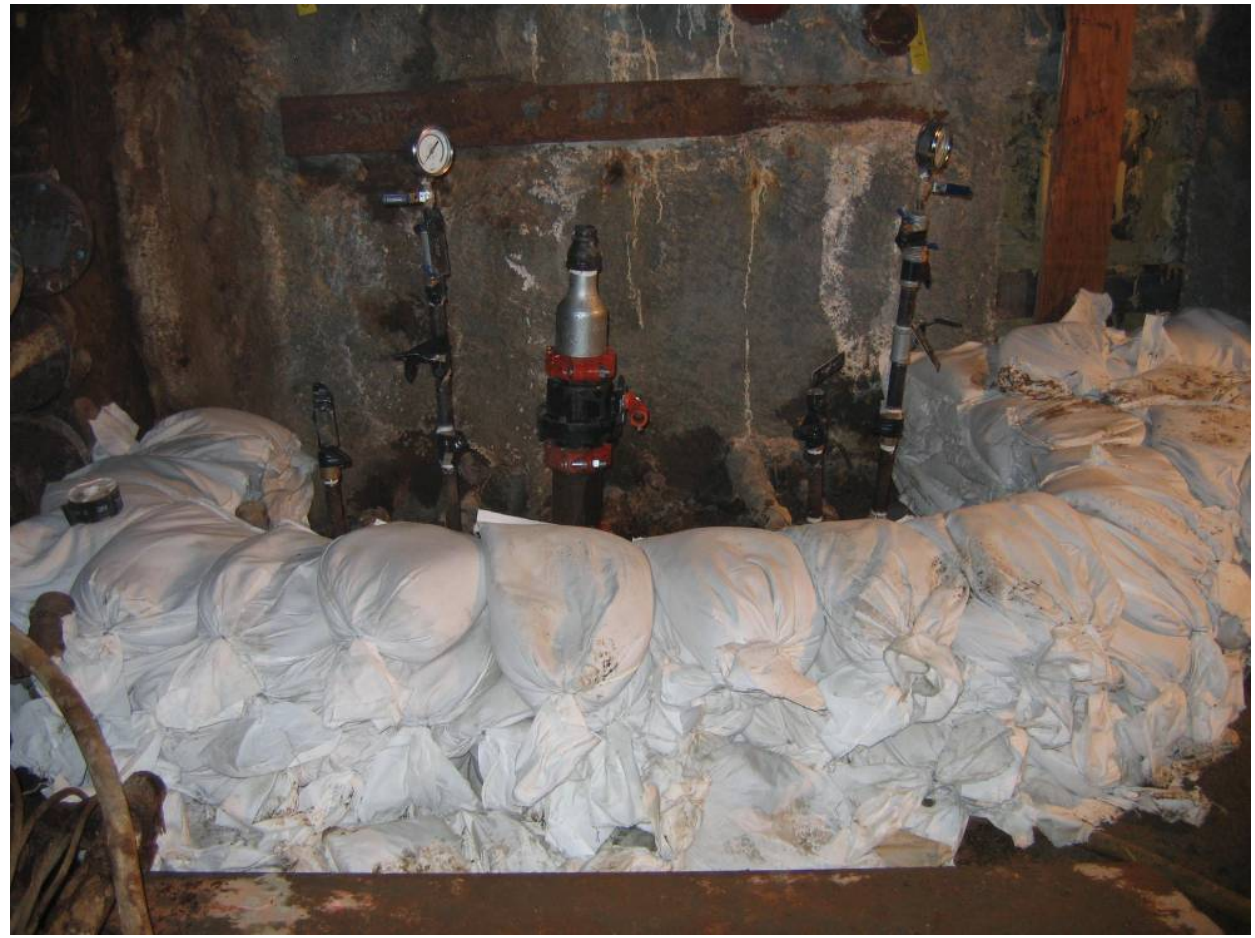

Photograph 8: Area around sample and drain lines sandbagged for sarcophagus concrete pour, 10/25/2006 


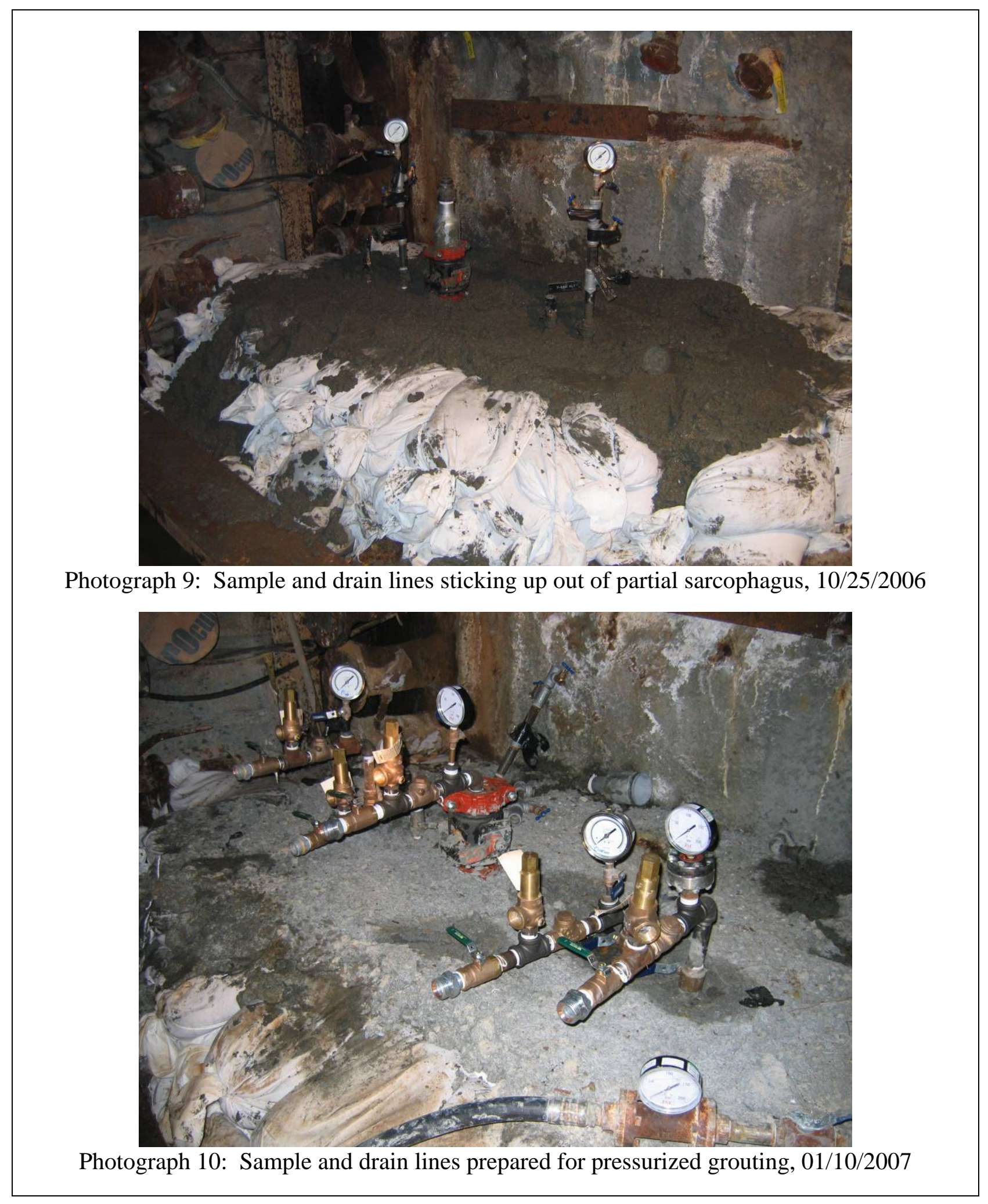




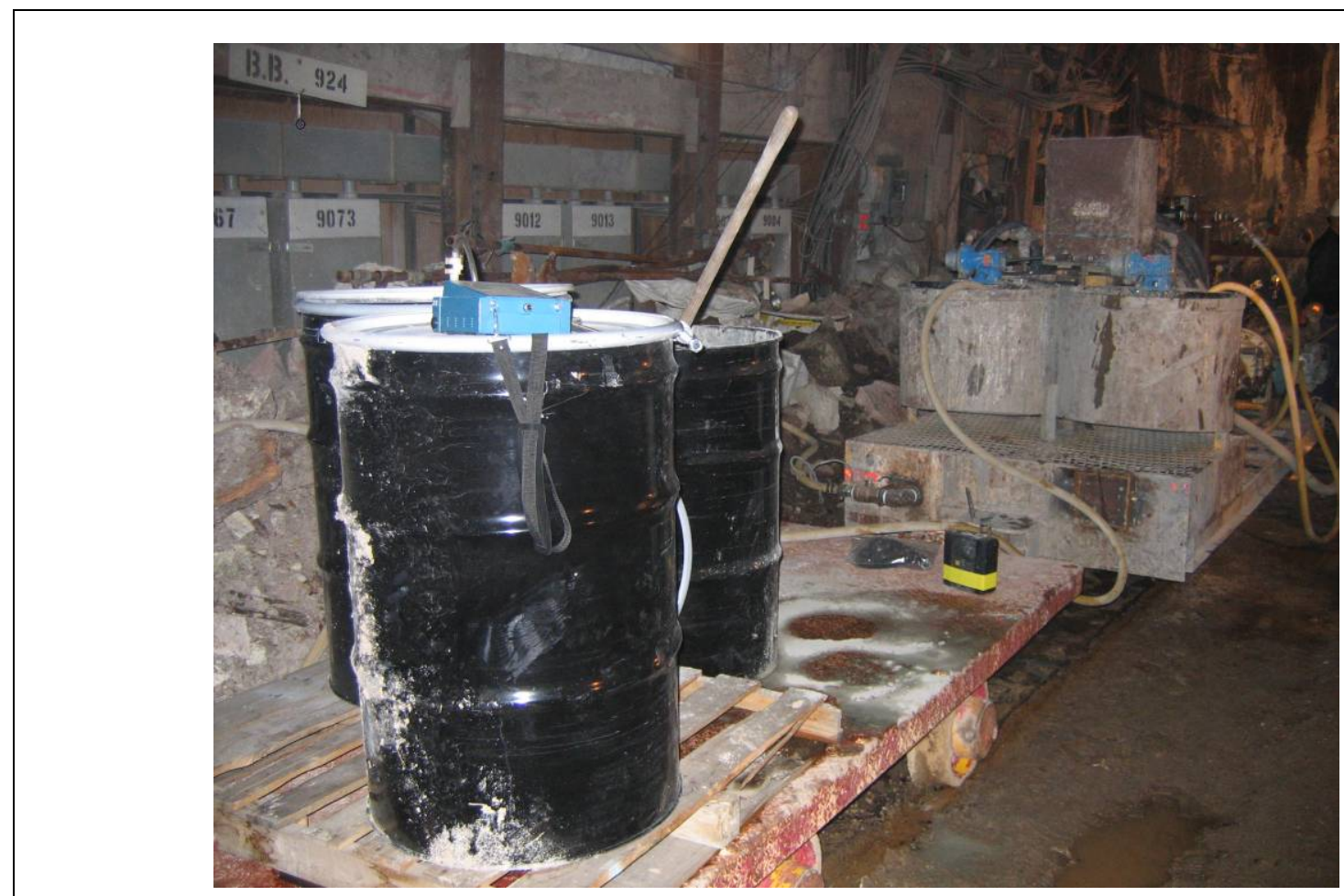

Photograph 11: Grout pumps (right side of photo) used to fill sample and drain lines, 01/10/2007

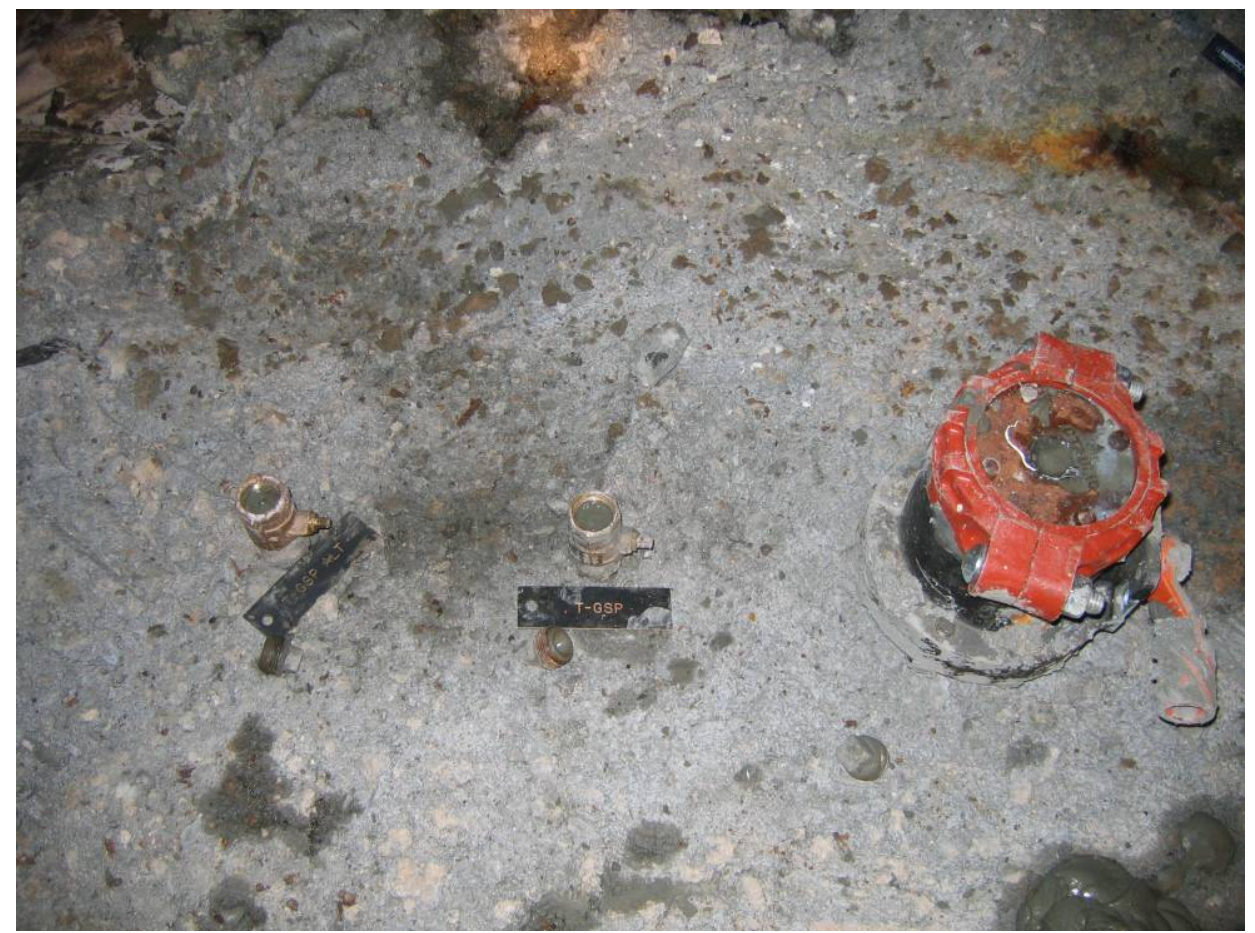

Photograph 12: GSP sample lines, grout-filled, 01/10/2007 


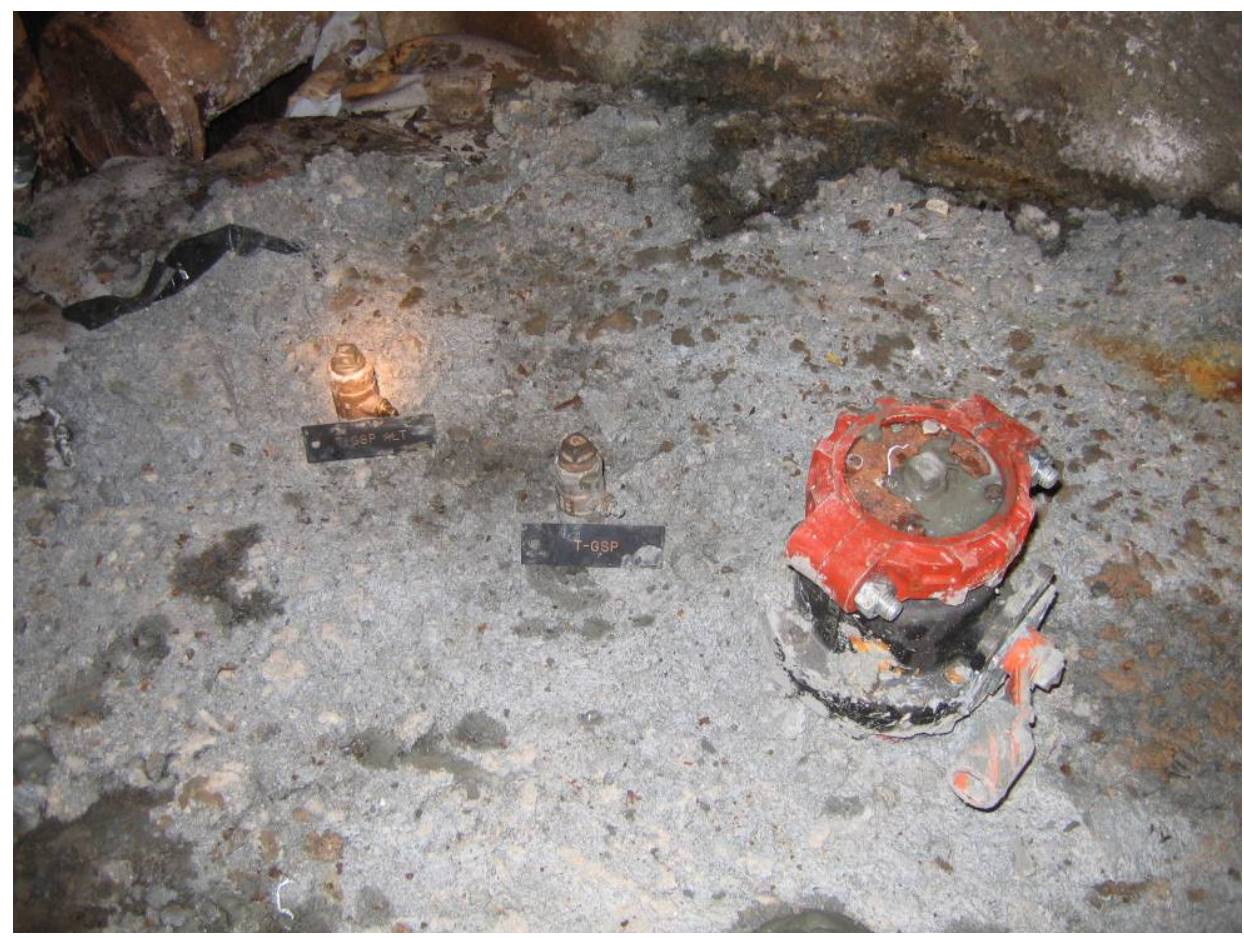

Photograph 13: GSP sample lines, capped, 01/10/2007

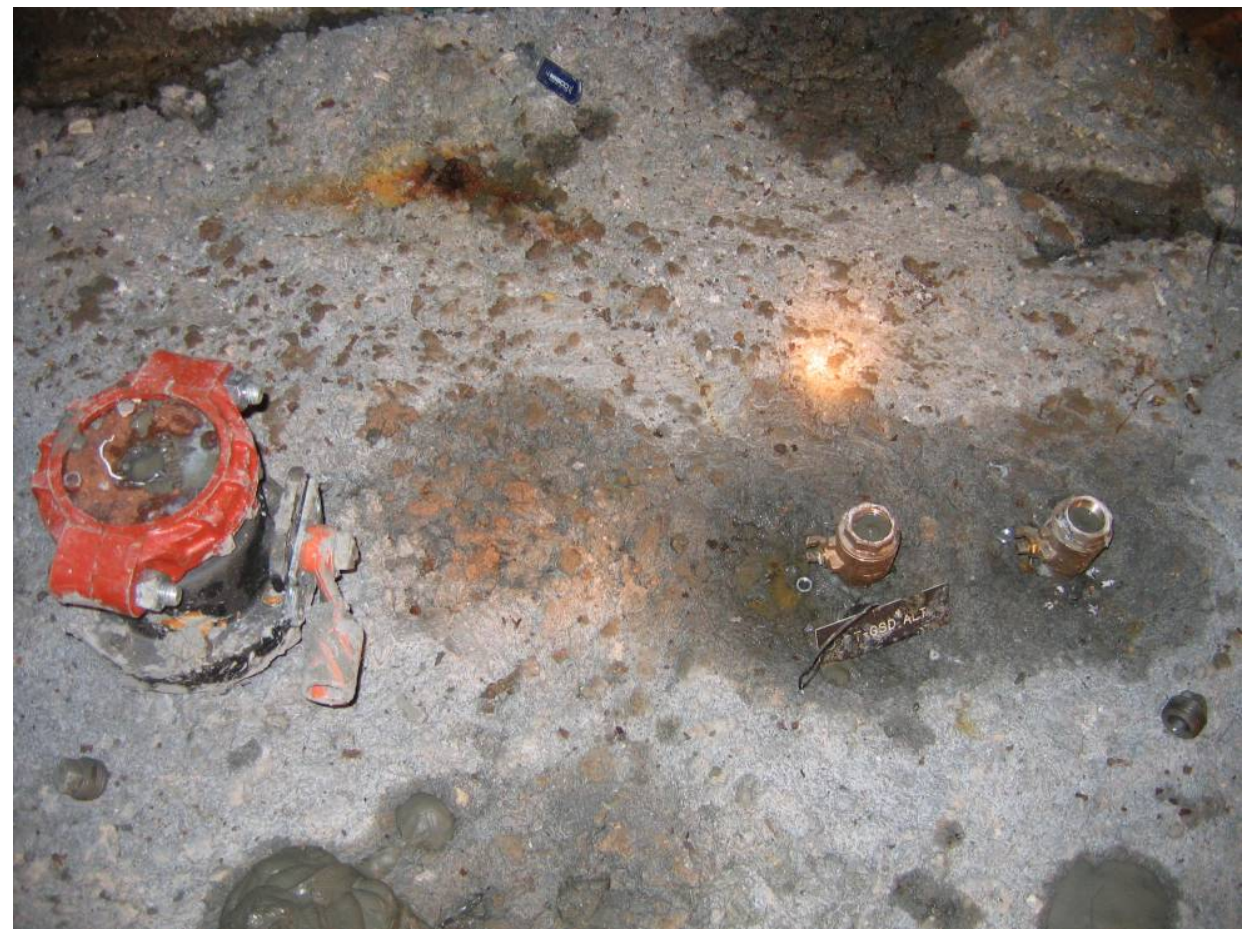

Photograph 14: GSD sample lines, grout-filled, 01/10/2007 


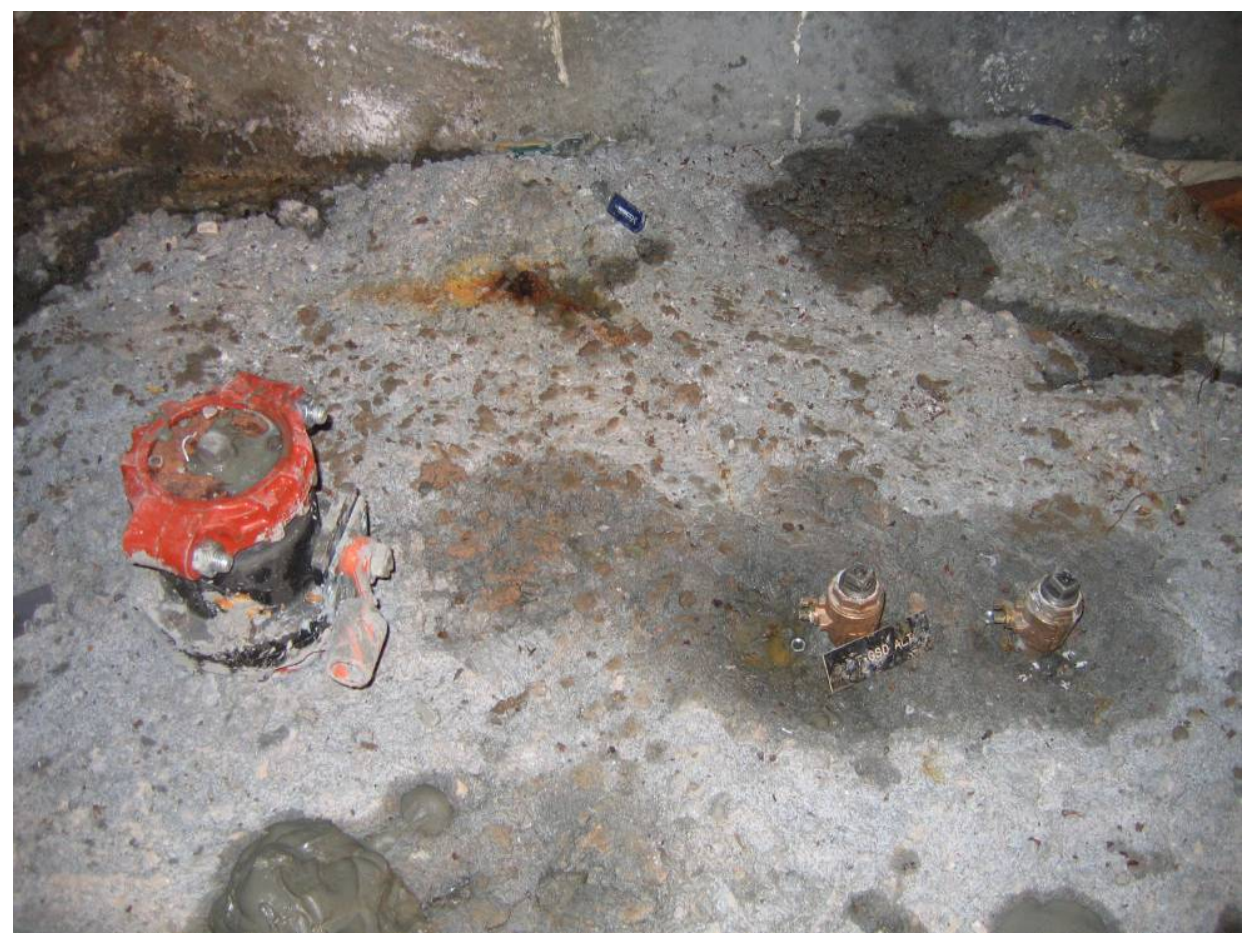

Photograph 15: GSD sample lines, capped, 01/10/2007

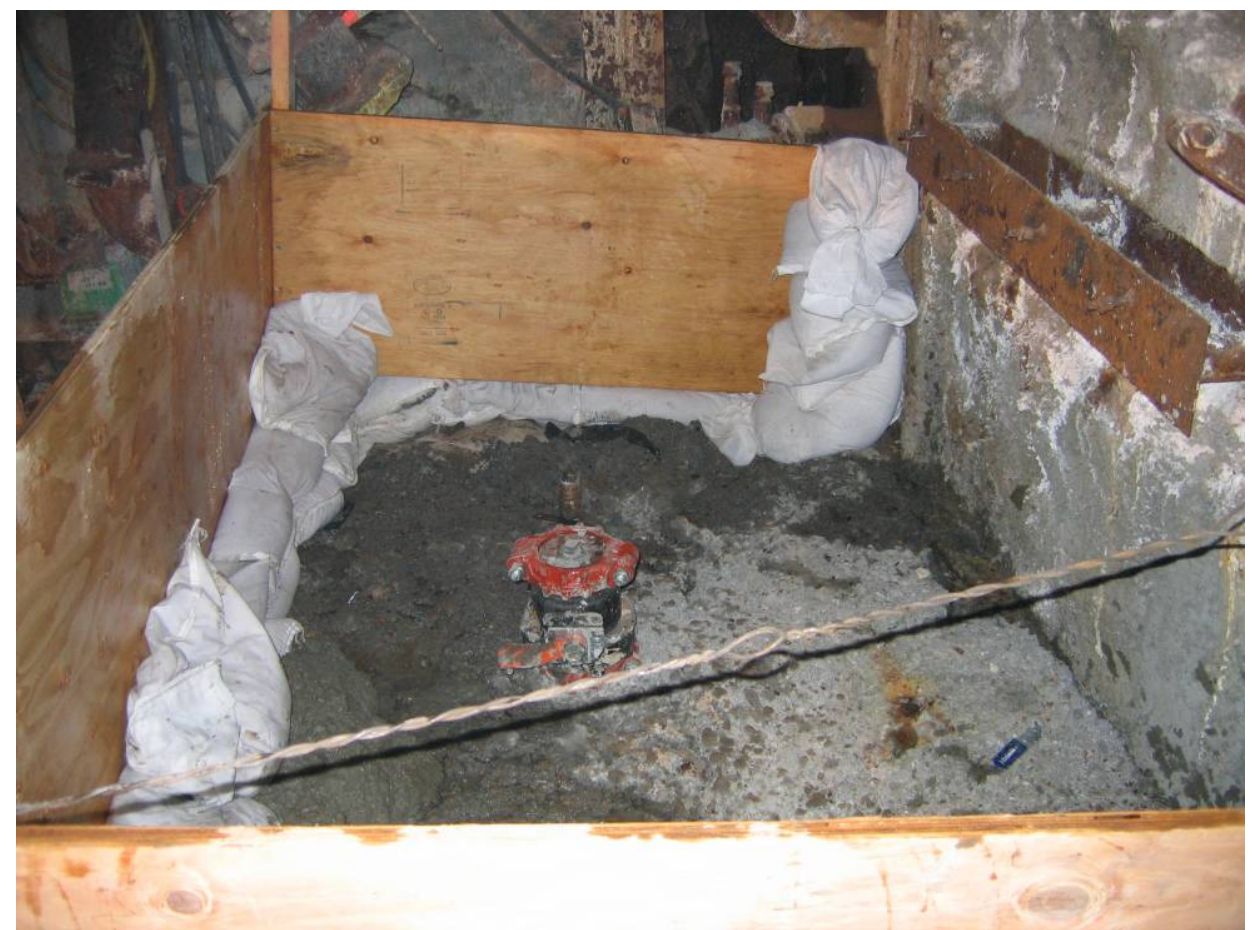

Photograph 16: Form erected for sarcophagus completion, 01/11/2007 


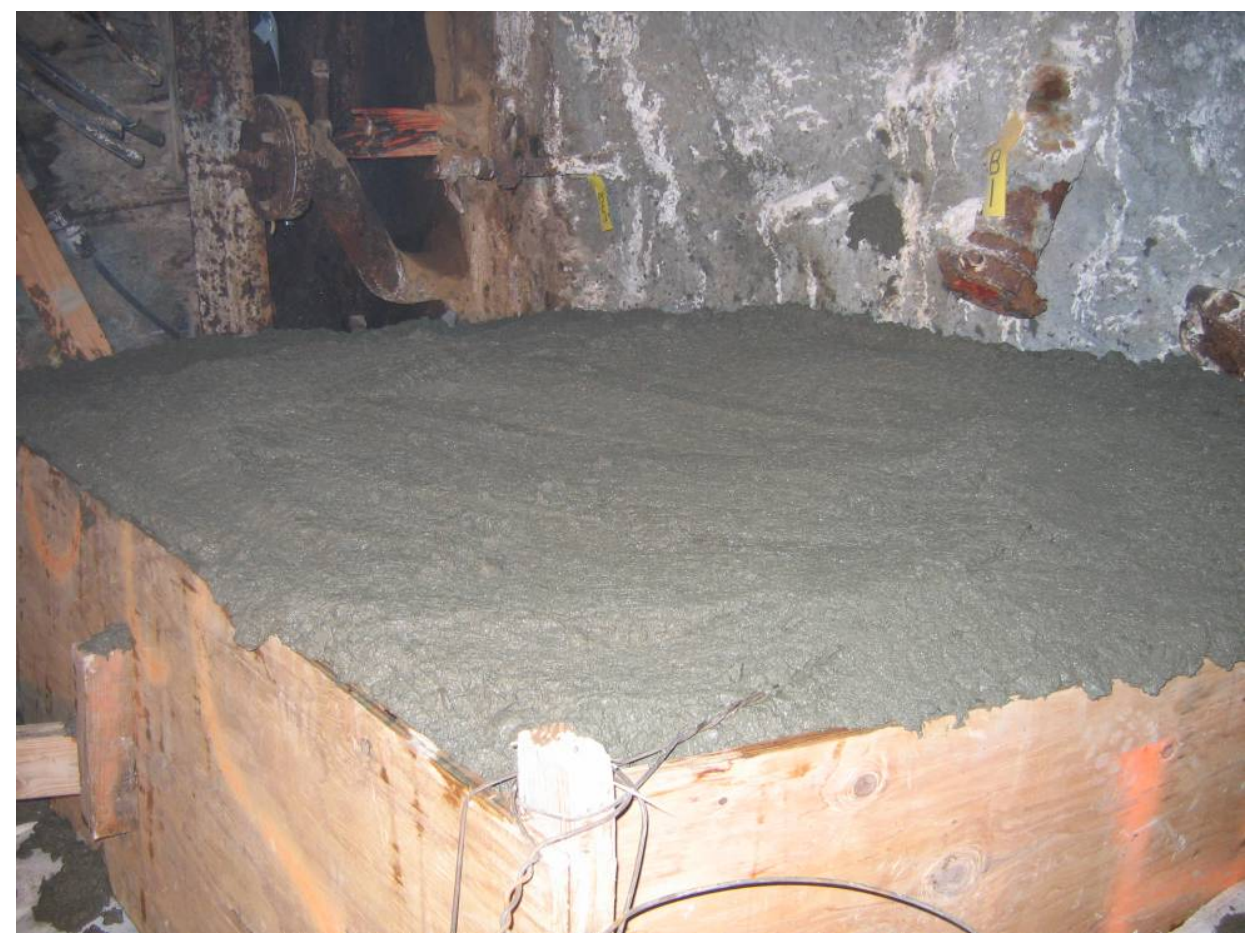

Photograph 17: Completed sarcophagus, 01/11/2007

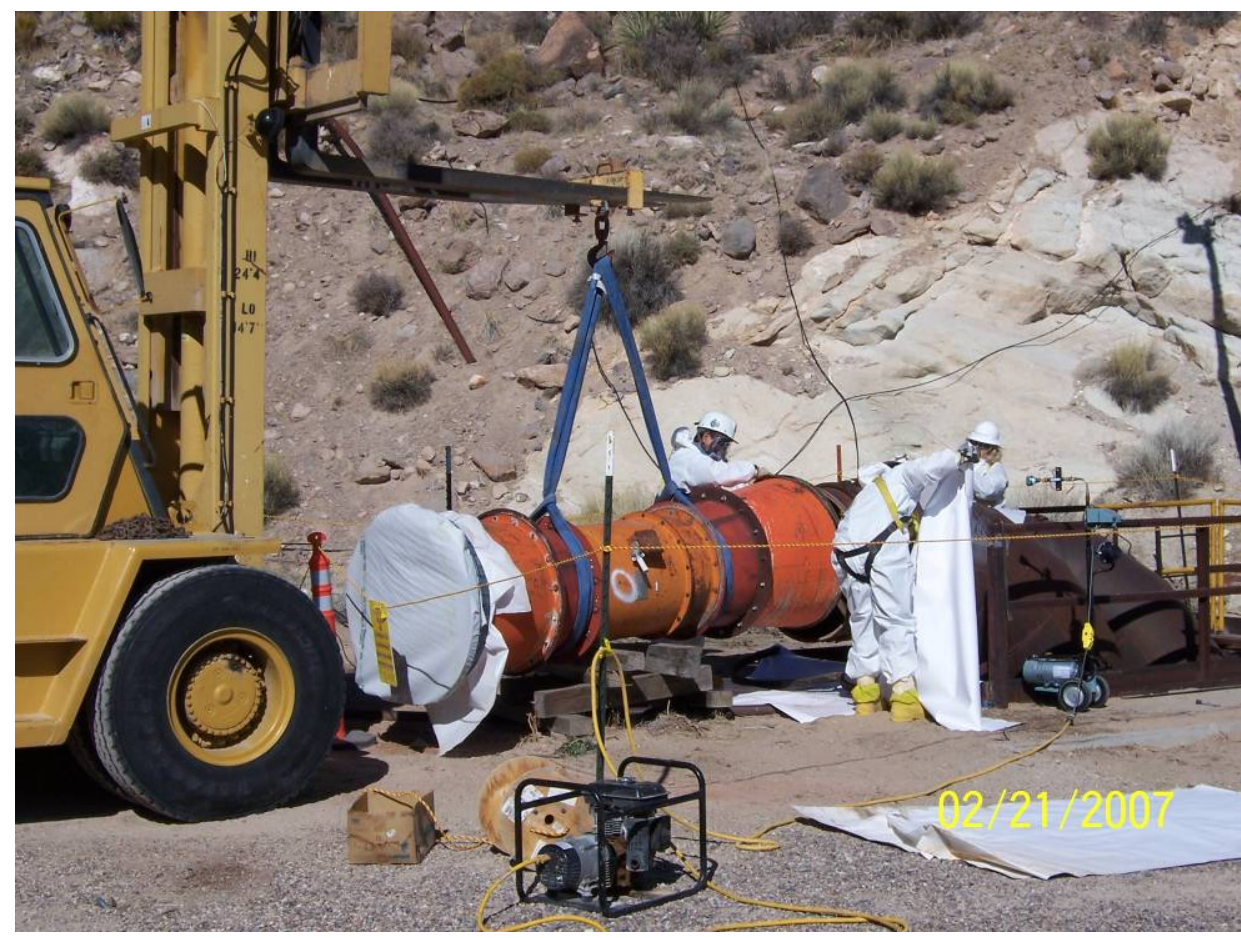

Photograph 18: Vent piping from top of vent raise (at right) being covered to prevent spread of radioactive contamination, 02/21/2007 


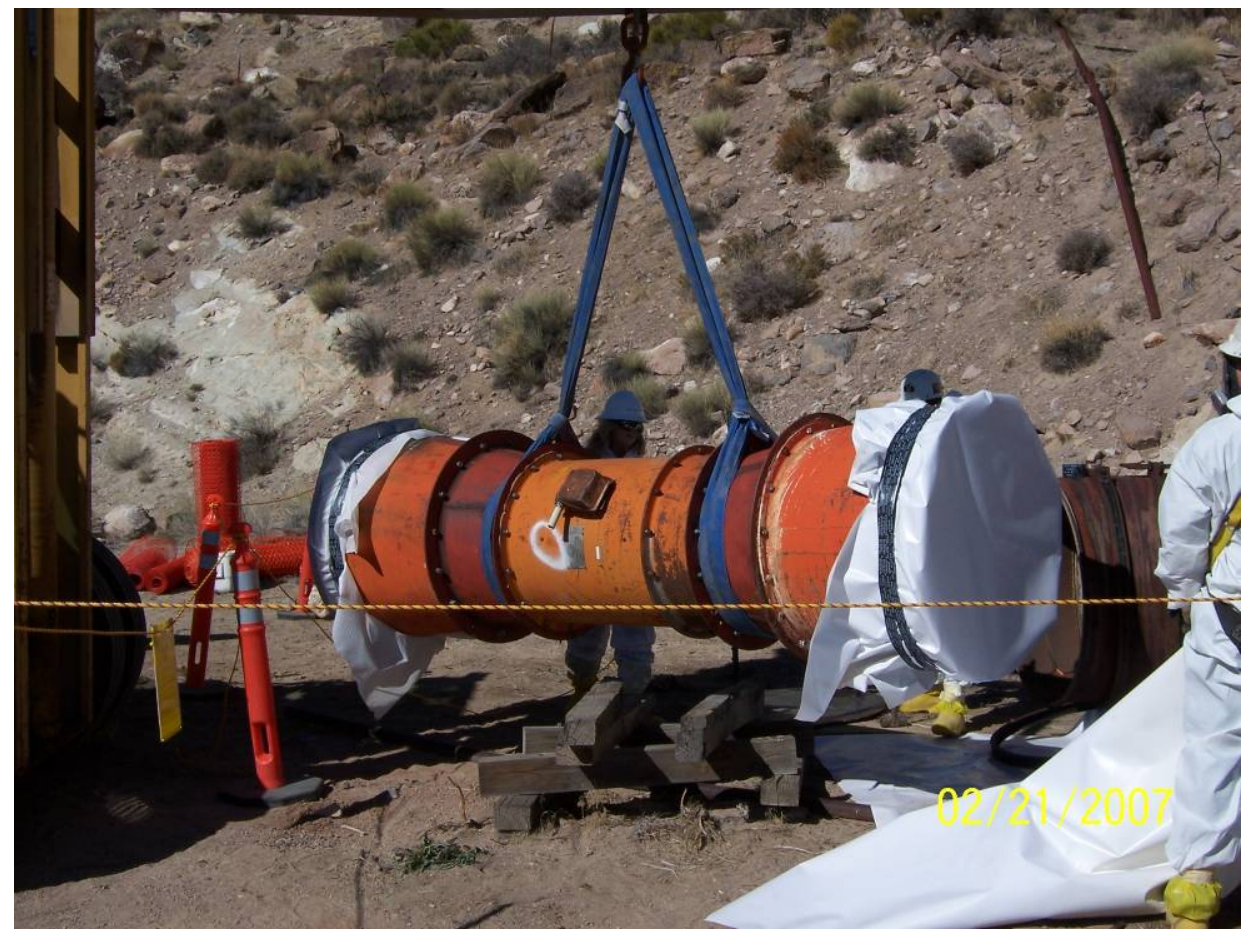

Photograph 19: Covered vent raise piping being removed, 02/21/2007

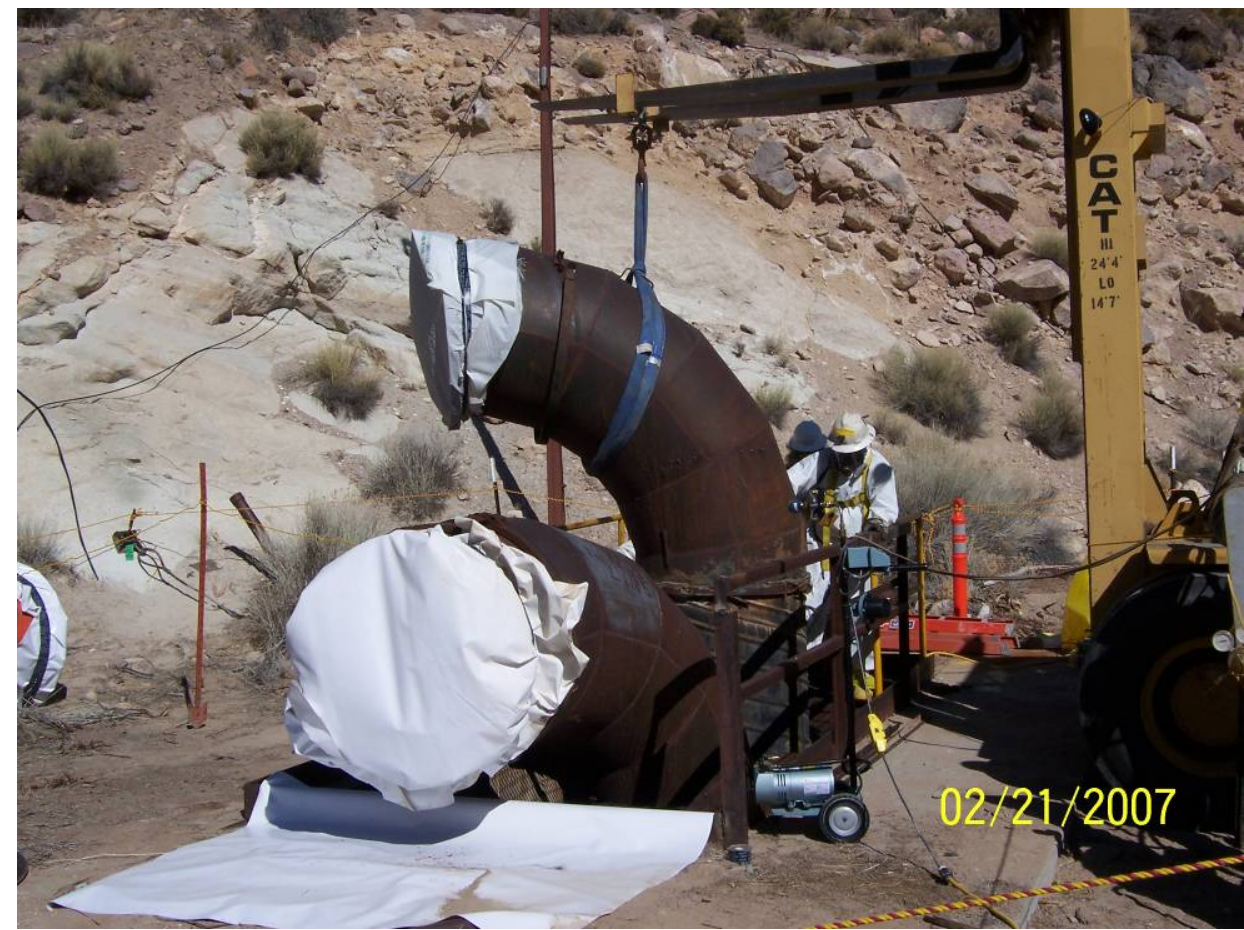

Photograph 20: Additional vent raise piping being covered and removed, 02/21/2007 


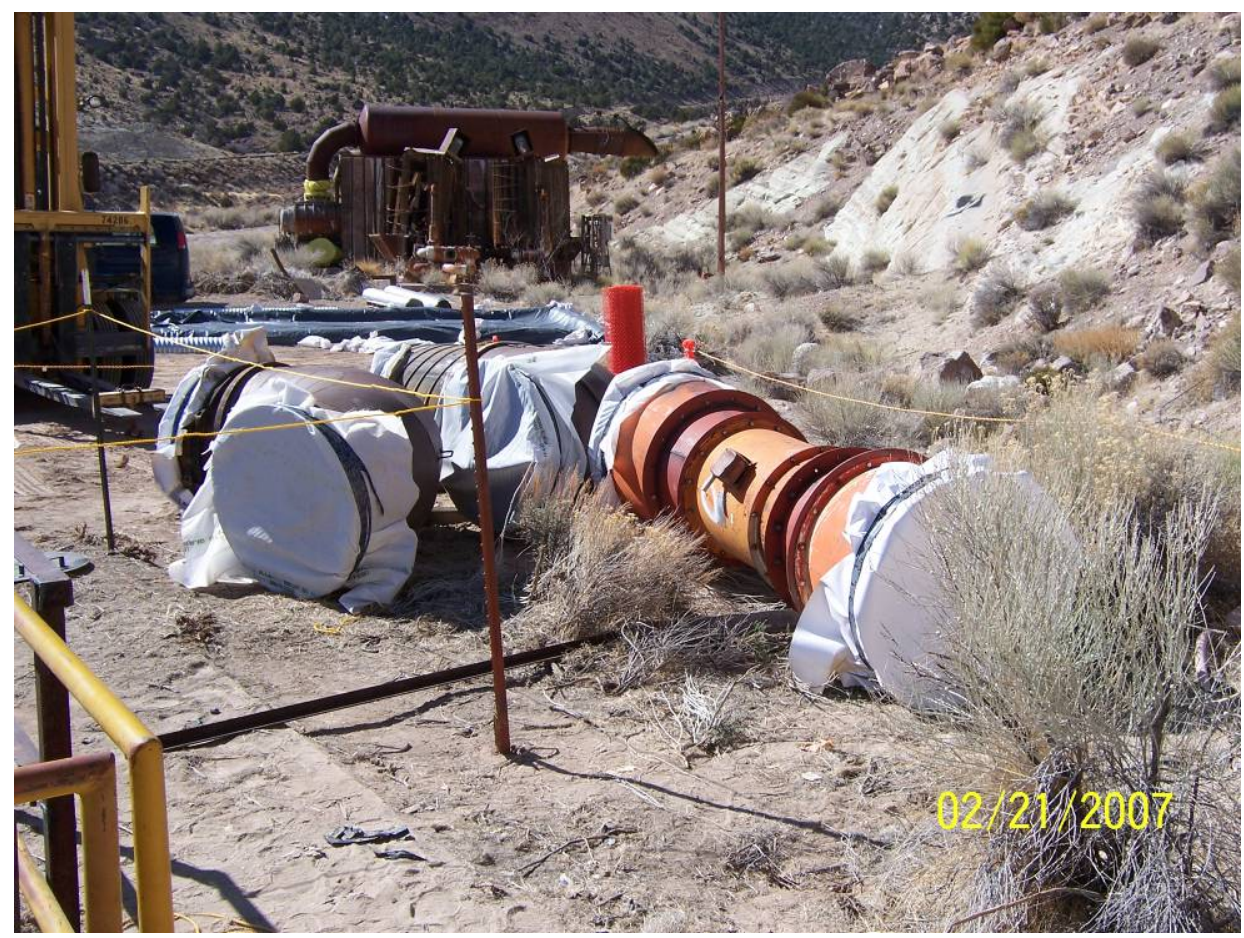

Photograph 21: Removed vent raise piping in Radioactive Material Area pending transfer to tunnel, 02/21/2007

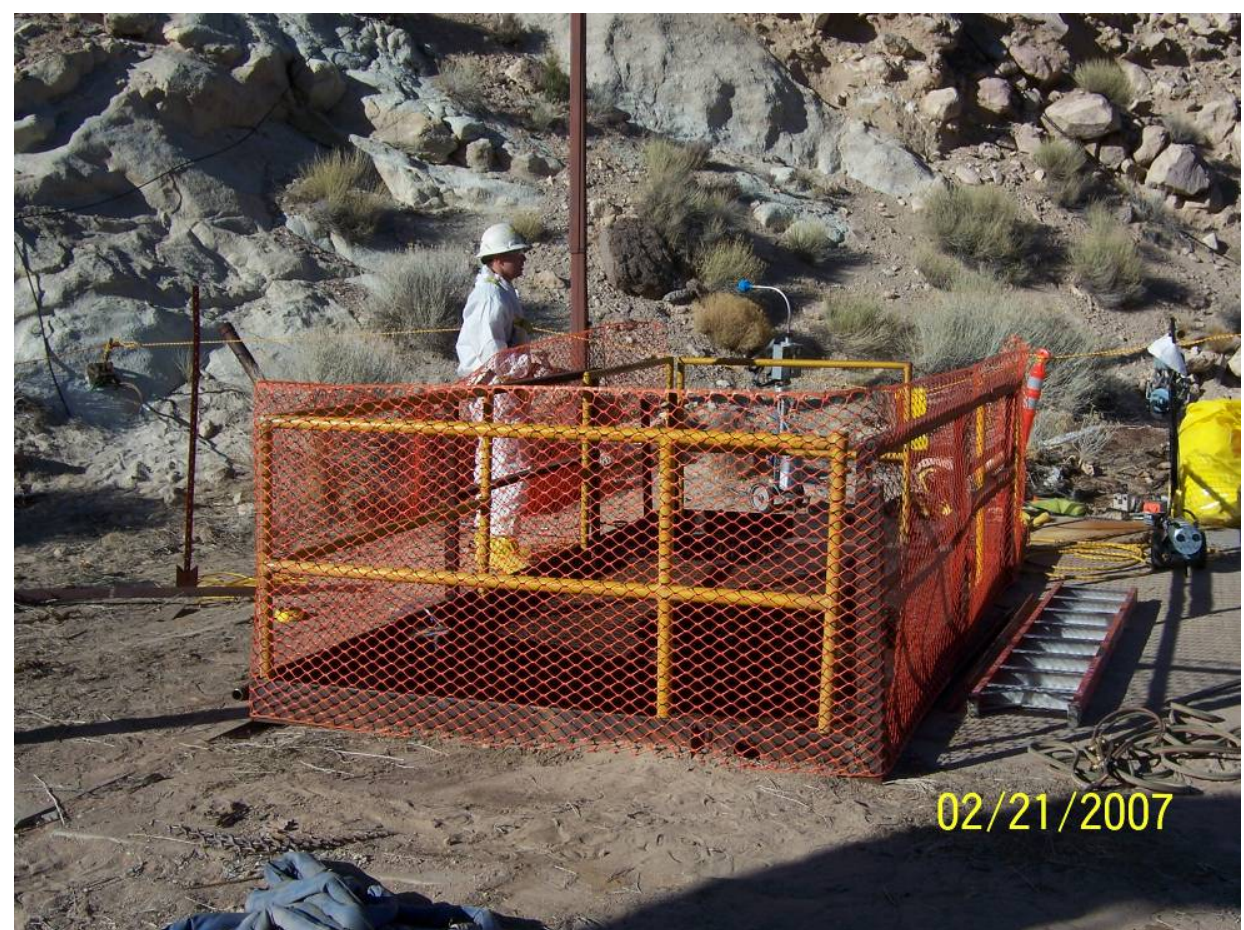

Photograph 22: Top of vent raise after vent piping has been removed, 02/21/2007 


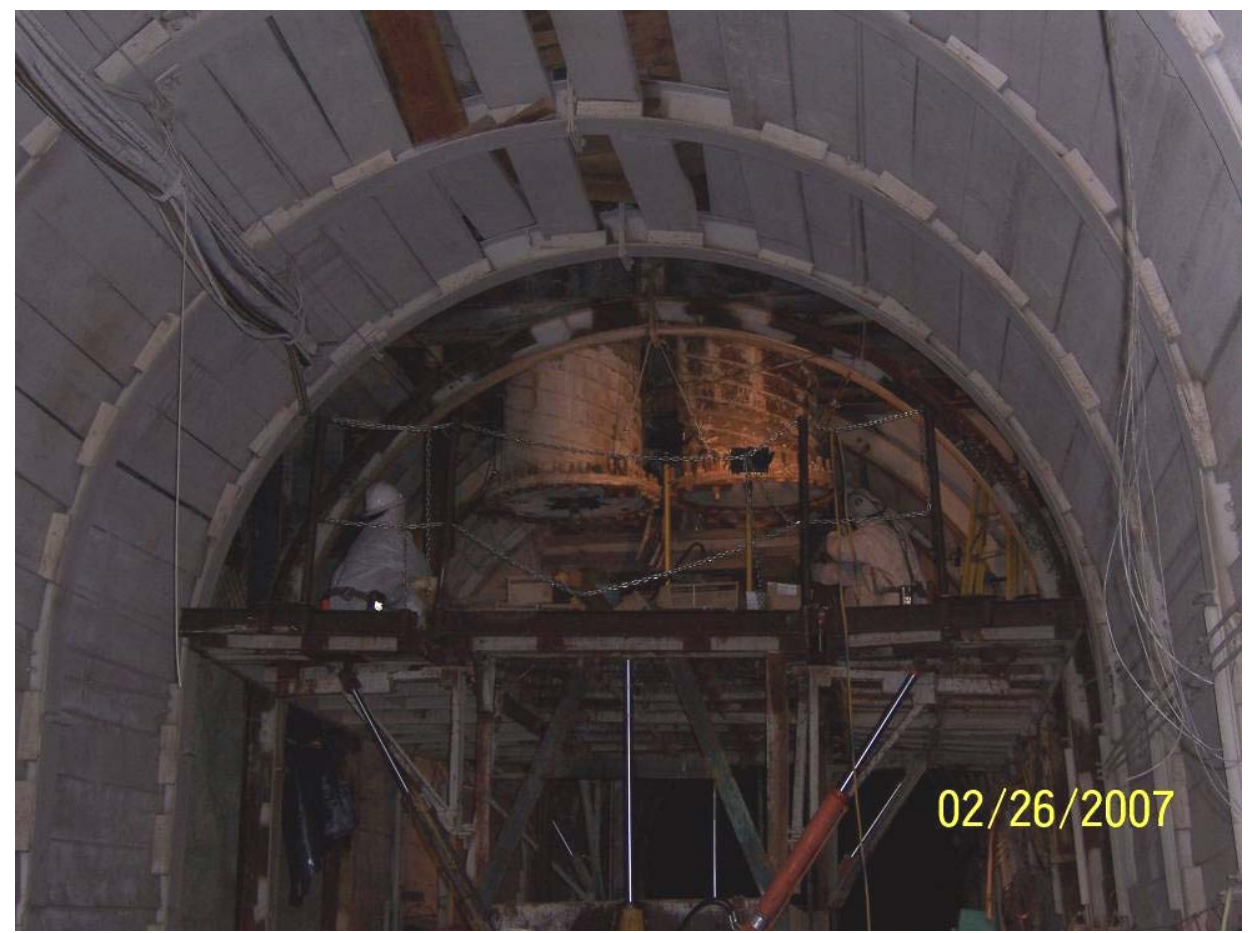

Photograph 23: Bottom of vent raise piping, inside T-Tunnel, 02/26/2007

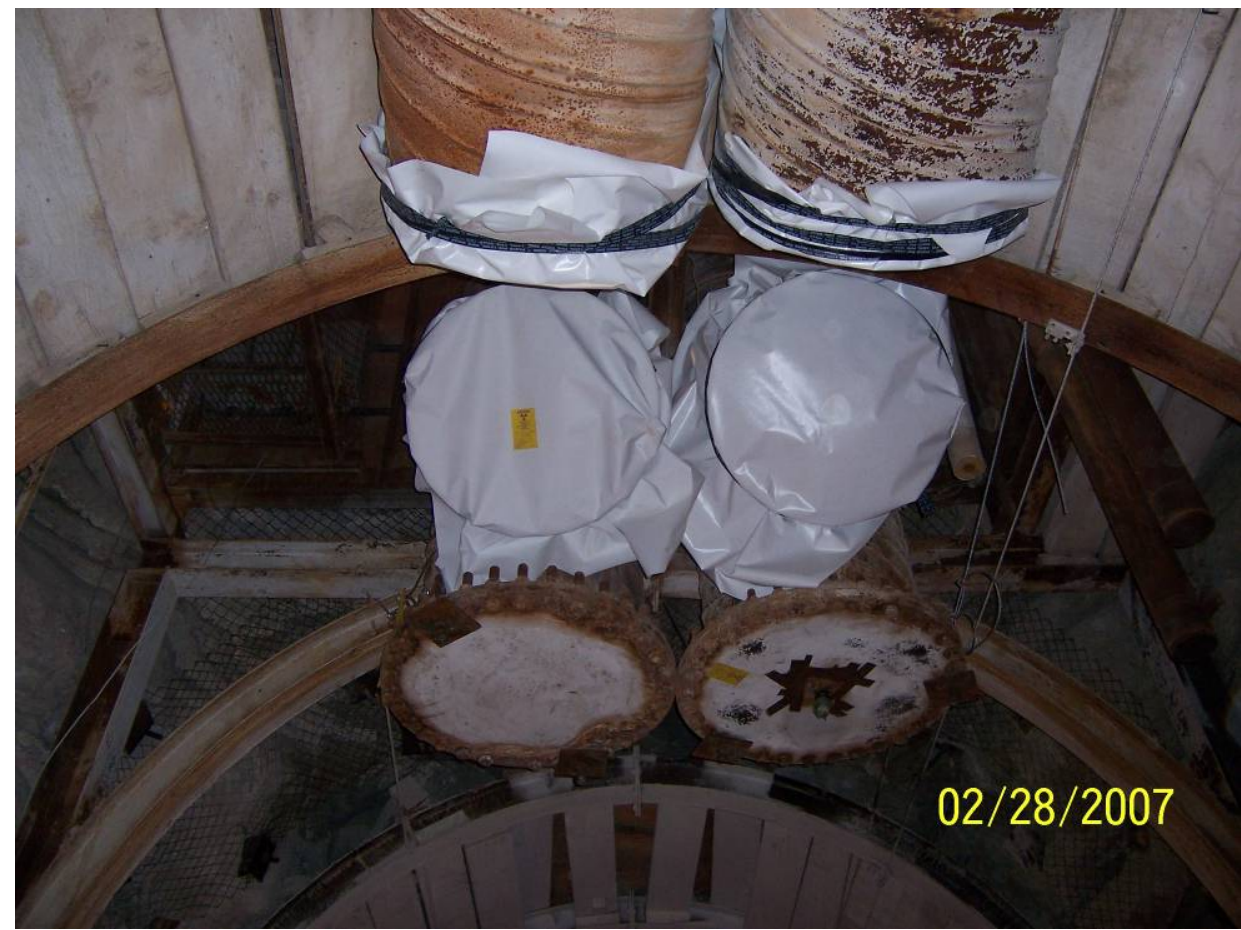

Photograph 24: Vent raise piping disconnected from tunnel vent piping and covered to prevent spread of radioactive contamination, 02/28/2007 


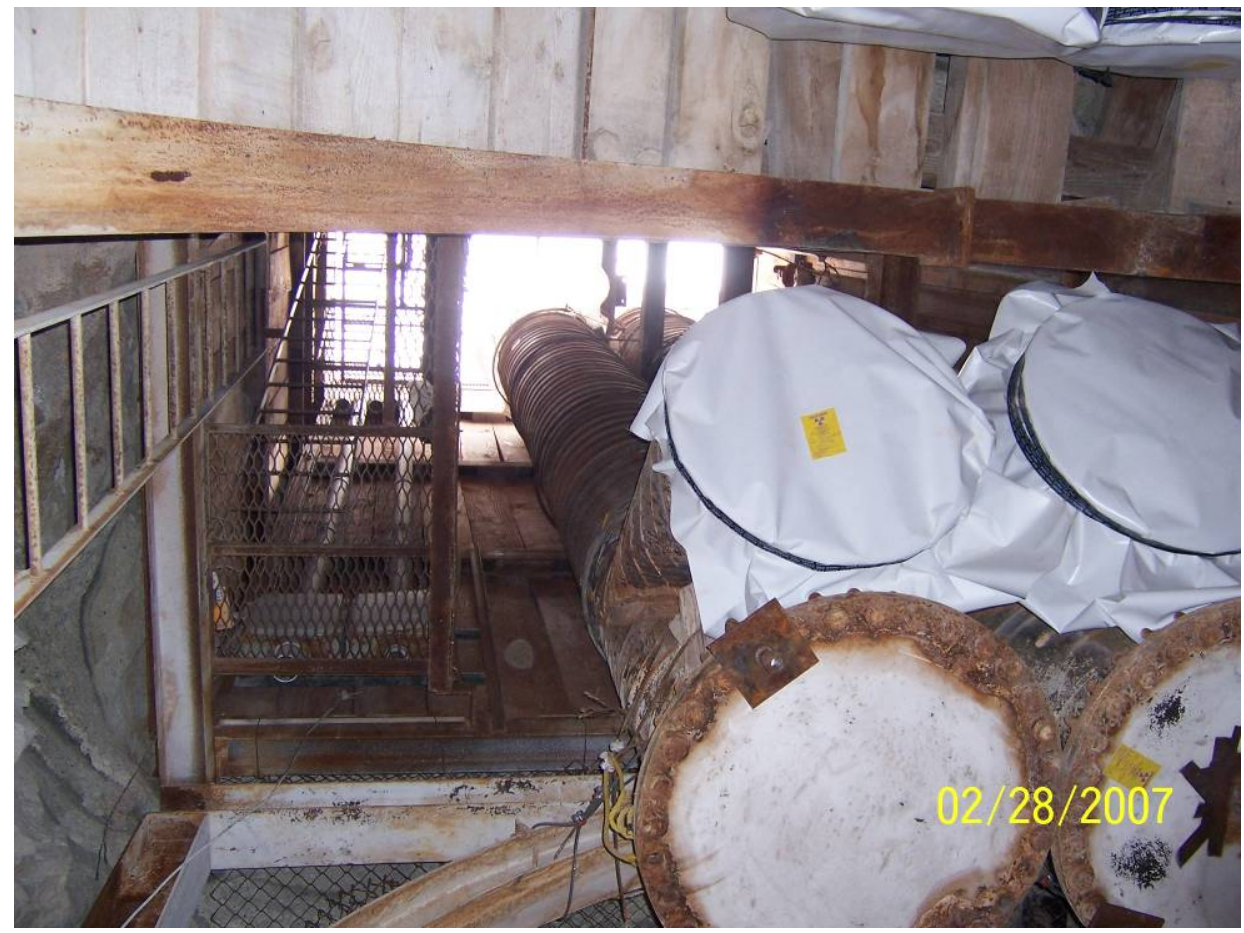

Photograph 25: View up vent raise from within T-Tunnel, 02/28/2007

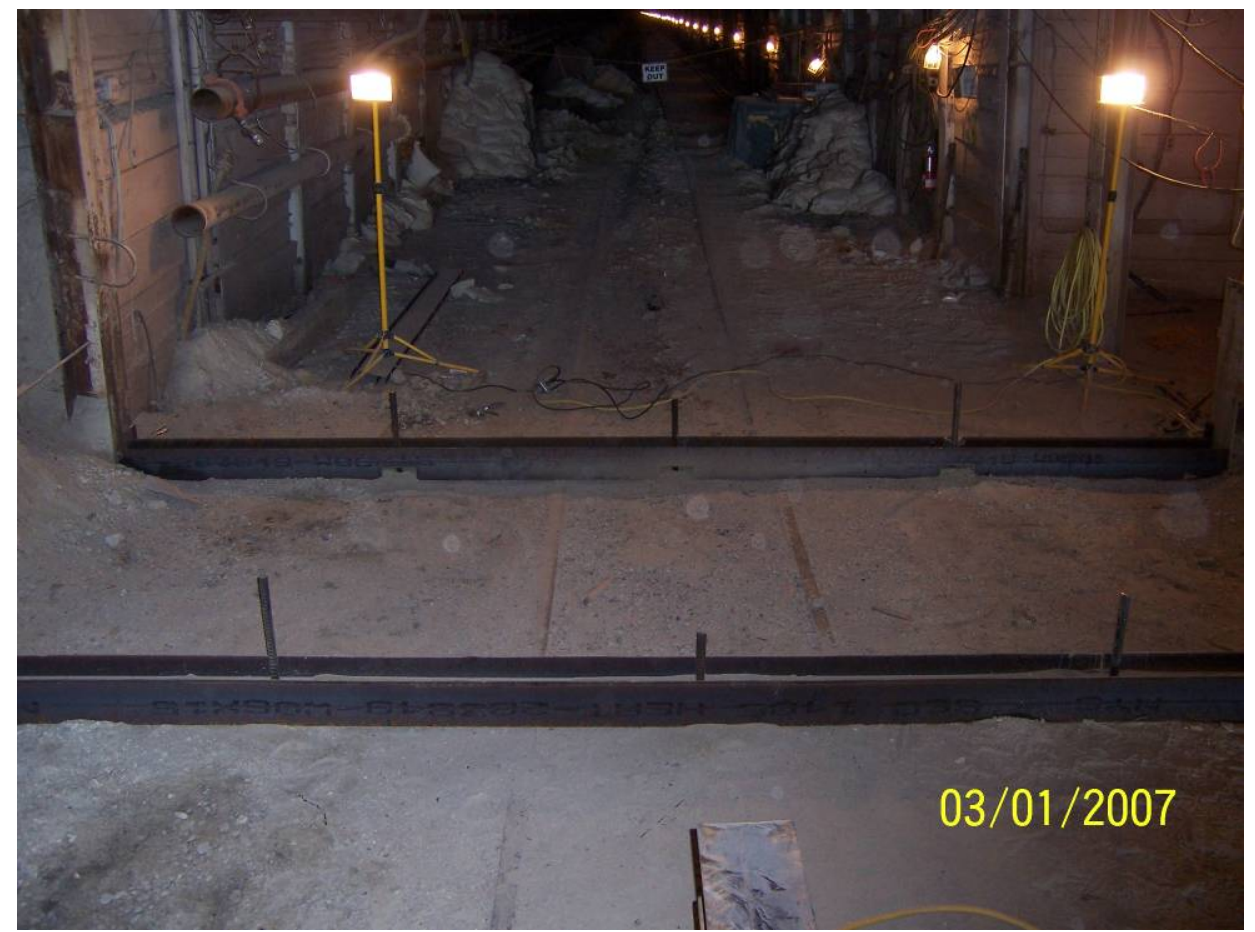

Photograph 26: Base framing for bulkhead, beneath the vent raise, 03/01/2007 


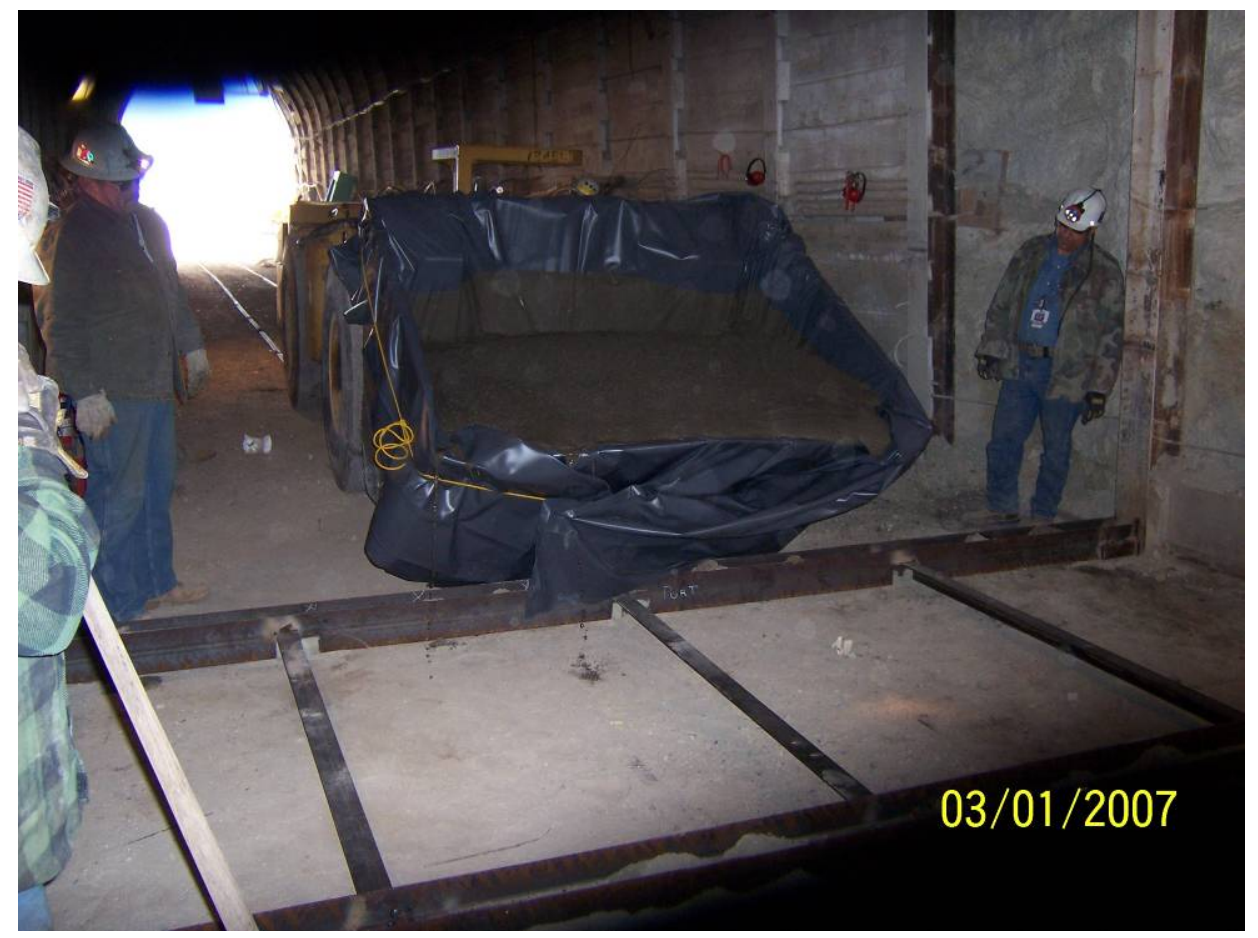

Photograph 27: Hauling in concrete for the bulkhead base, 03/01/2007

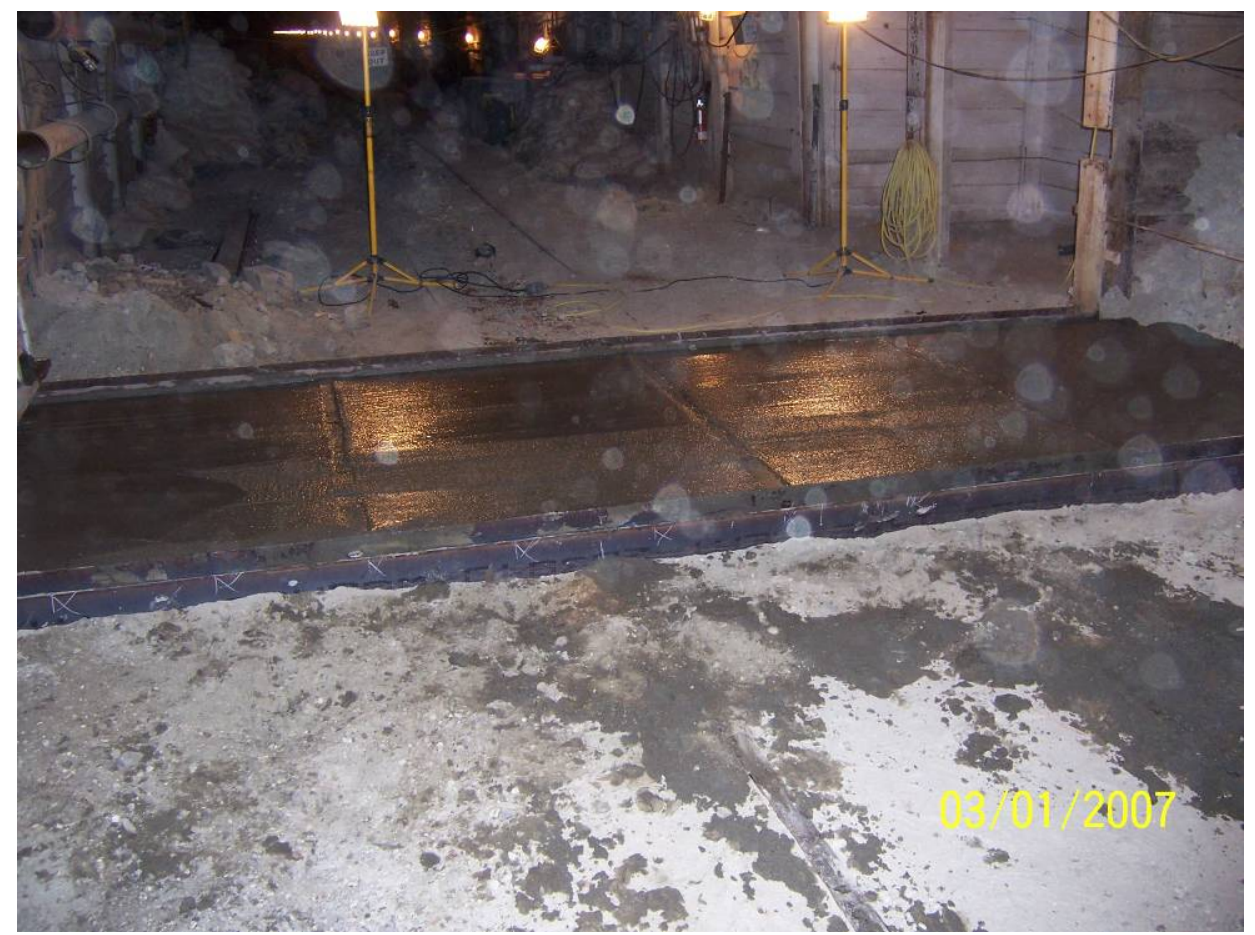

Photograph 28: Bulkhead concrete base, 03/01/2007 


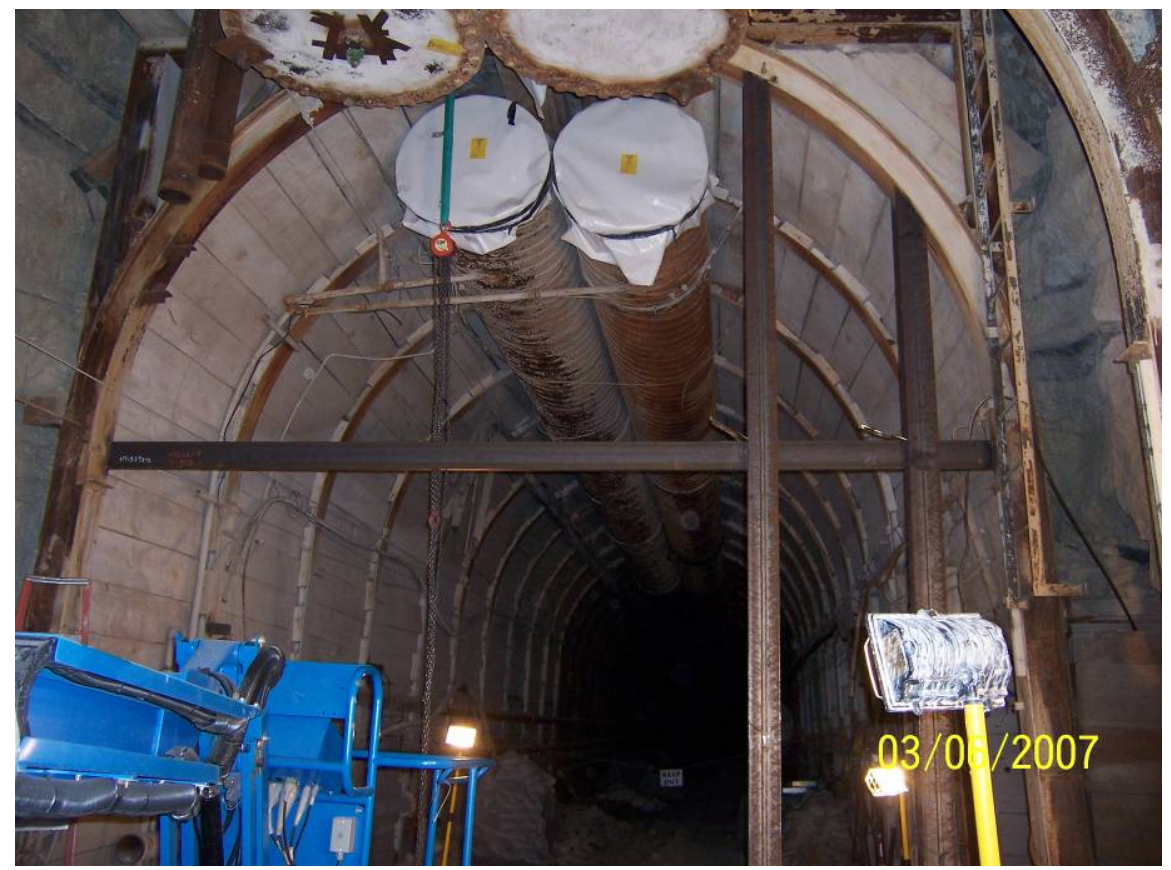

Photograph 29: Bulkhead framing, 03/06/2007

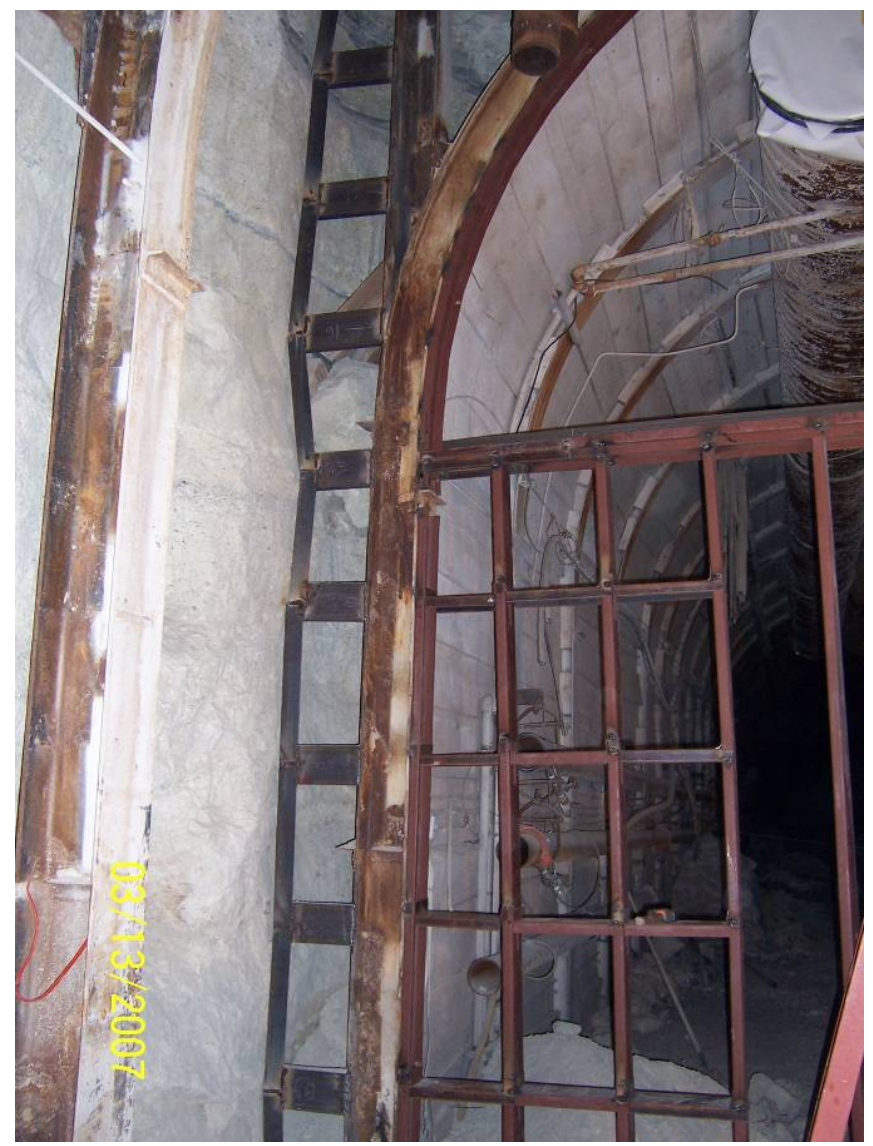

Photograph 30: Bulkhead framing, 03/13/2007 


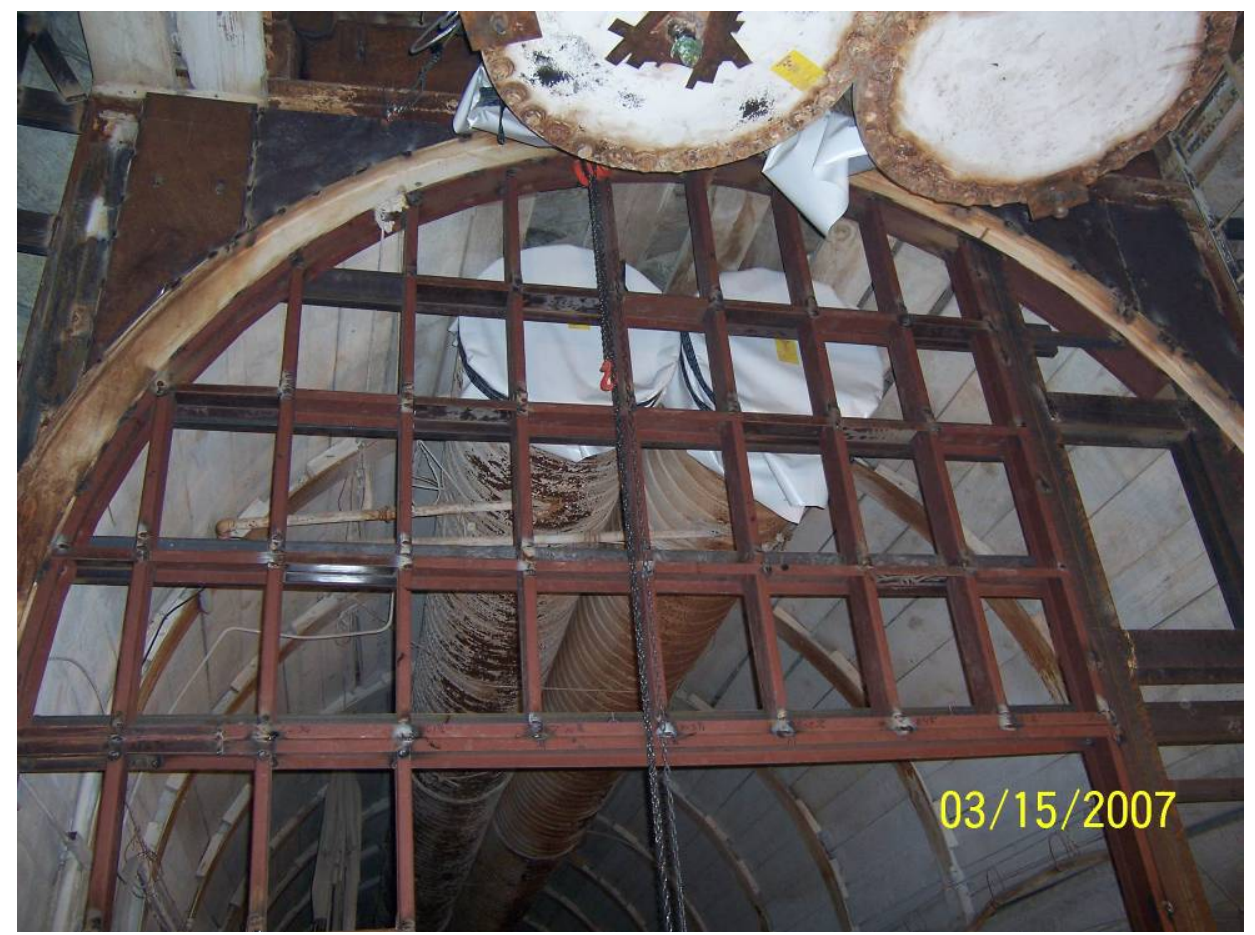

Photograph 31: Bulkhead framing, 03/15/2007

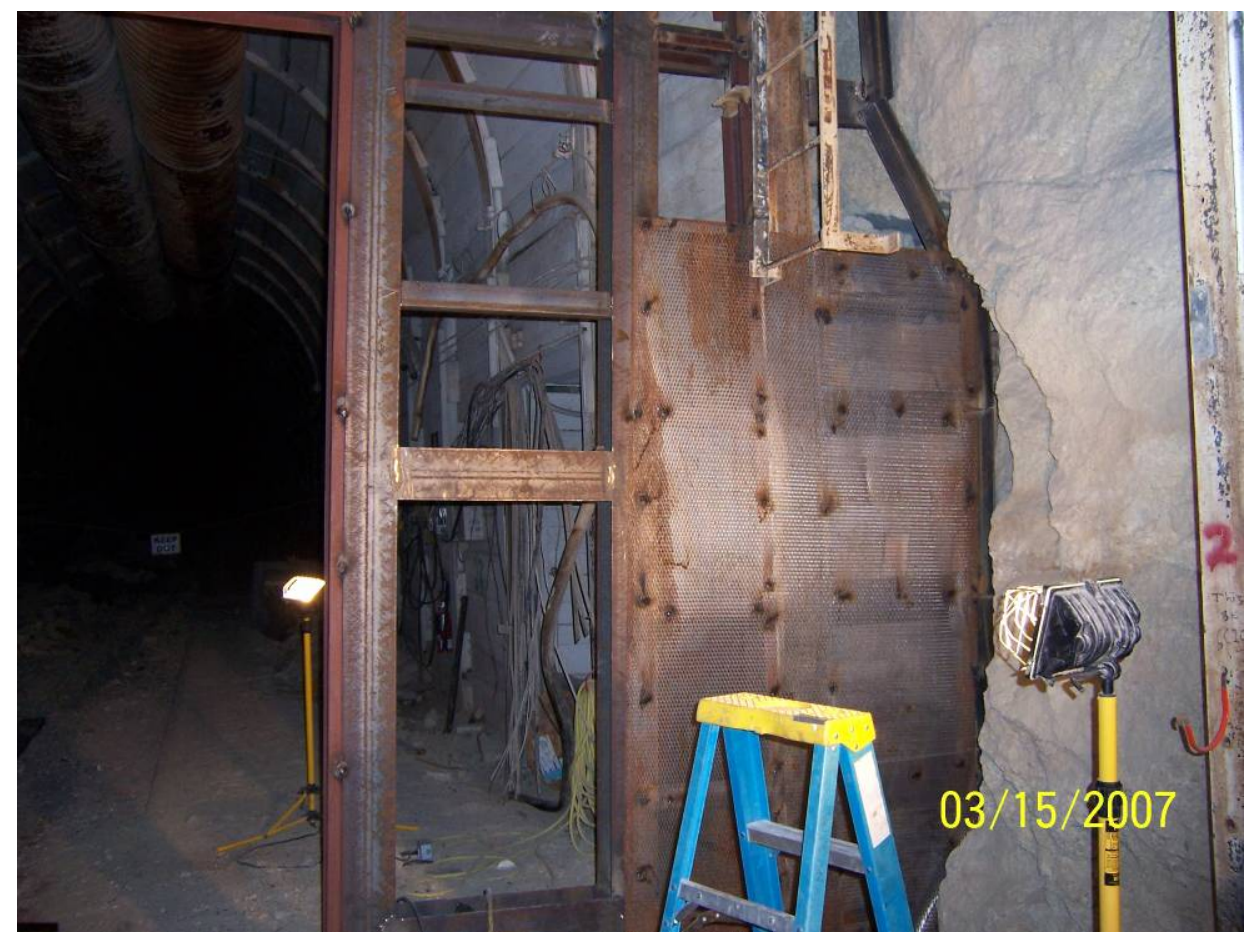

Photograph 32: Bulkhead framing with metal sheeting, 03/15/2007 


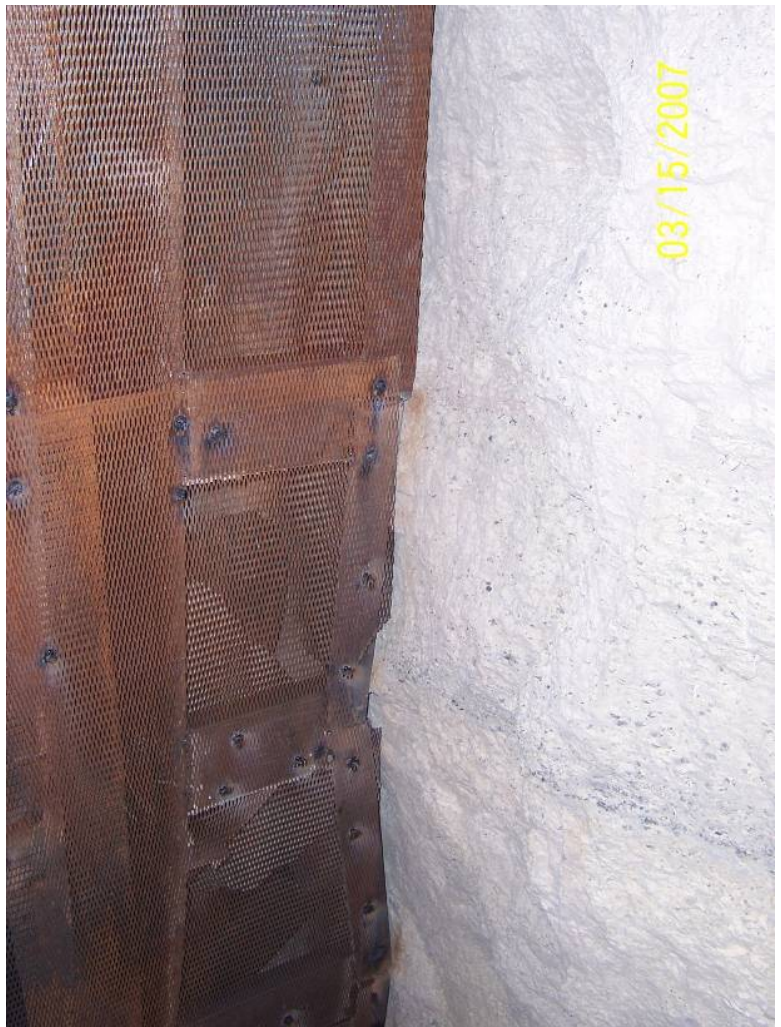

Photograph 33: Bulkhead frame with metal sheeting against tunnel wall, 03/15/2007

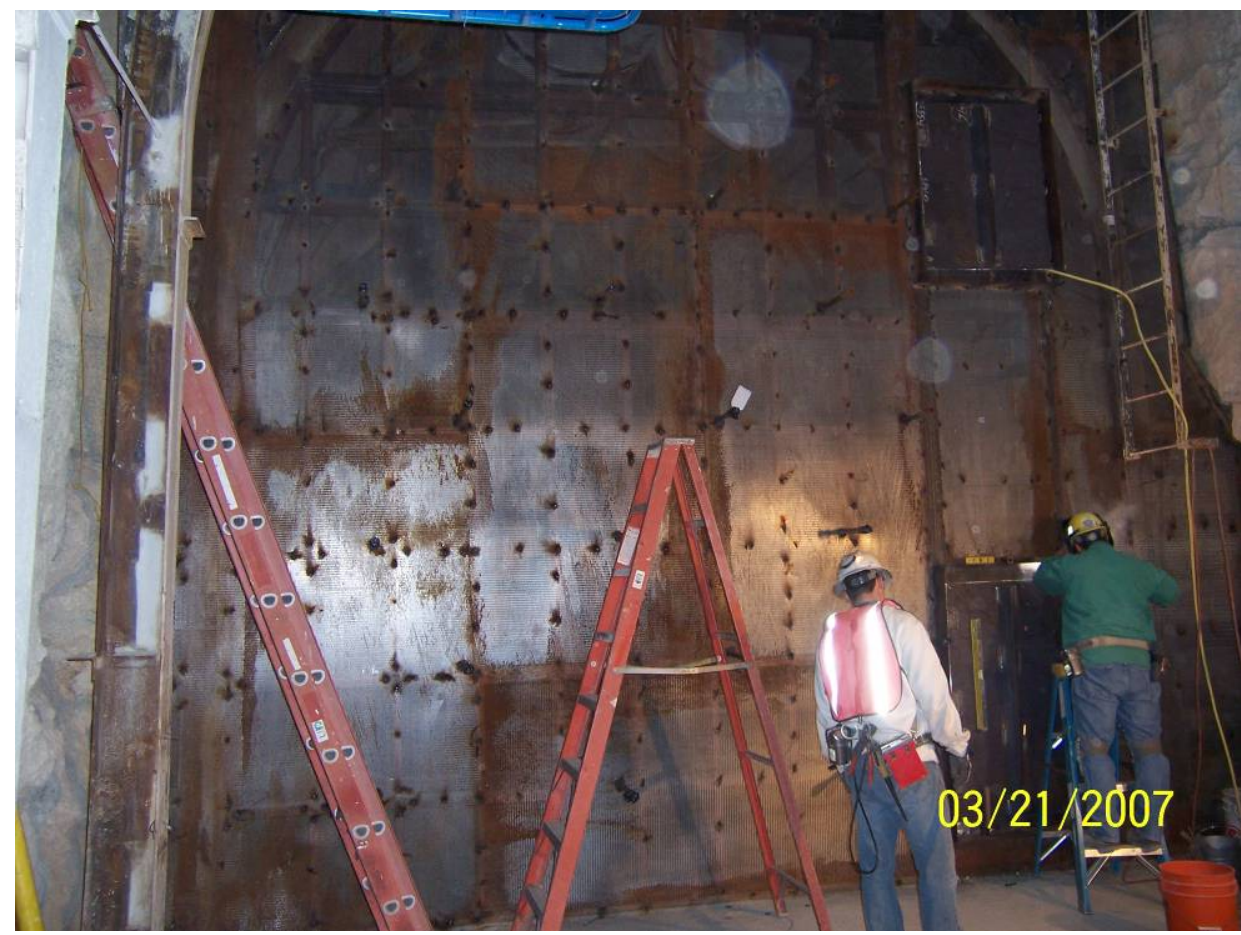

Photograph 34: Bulkhead framing and sheeting, view into tunnel, 03/21/2007 


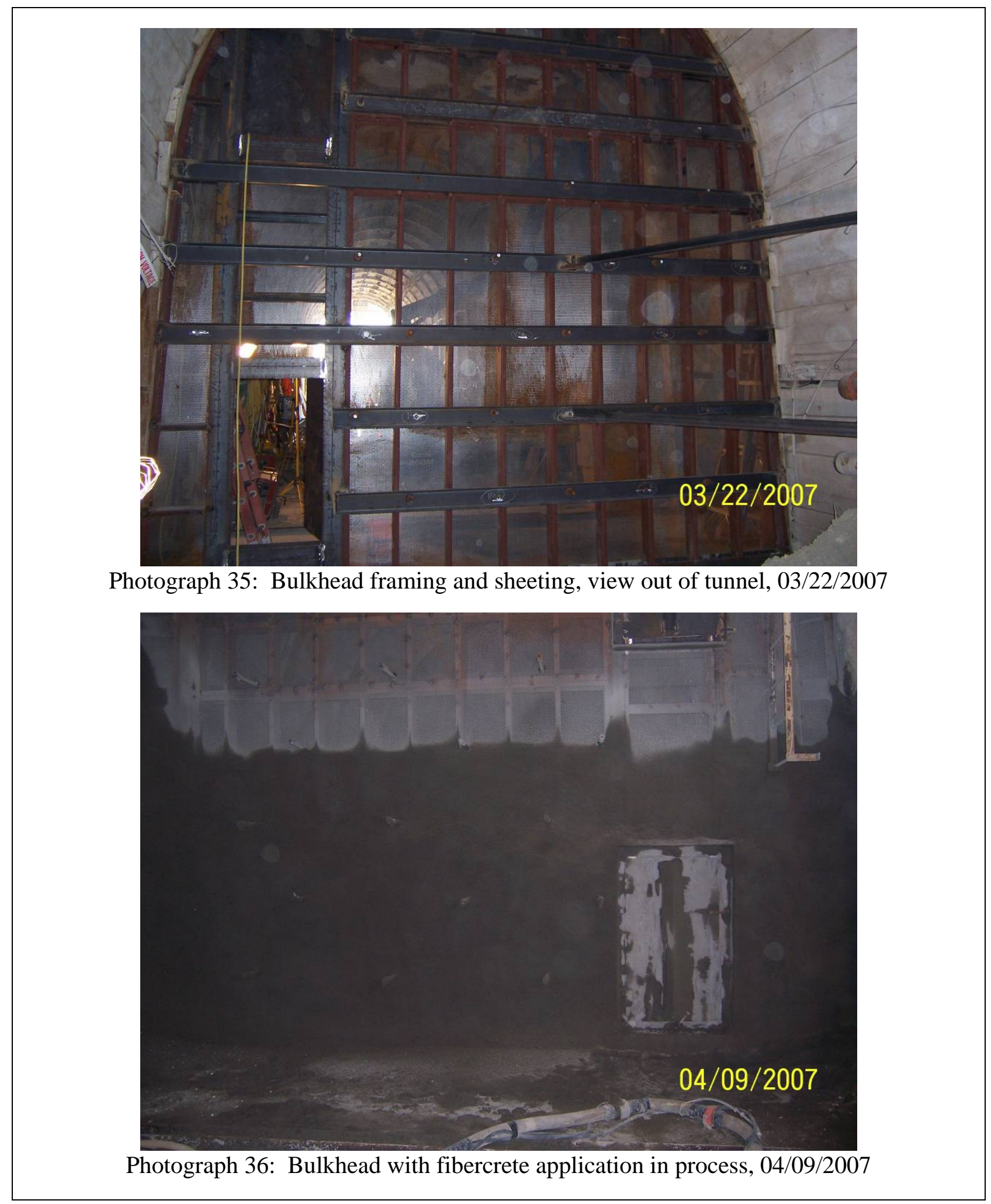




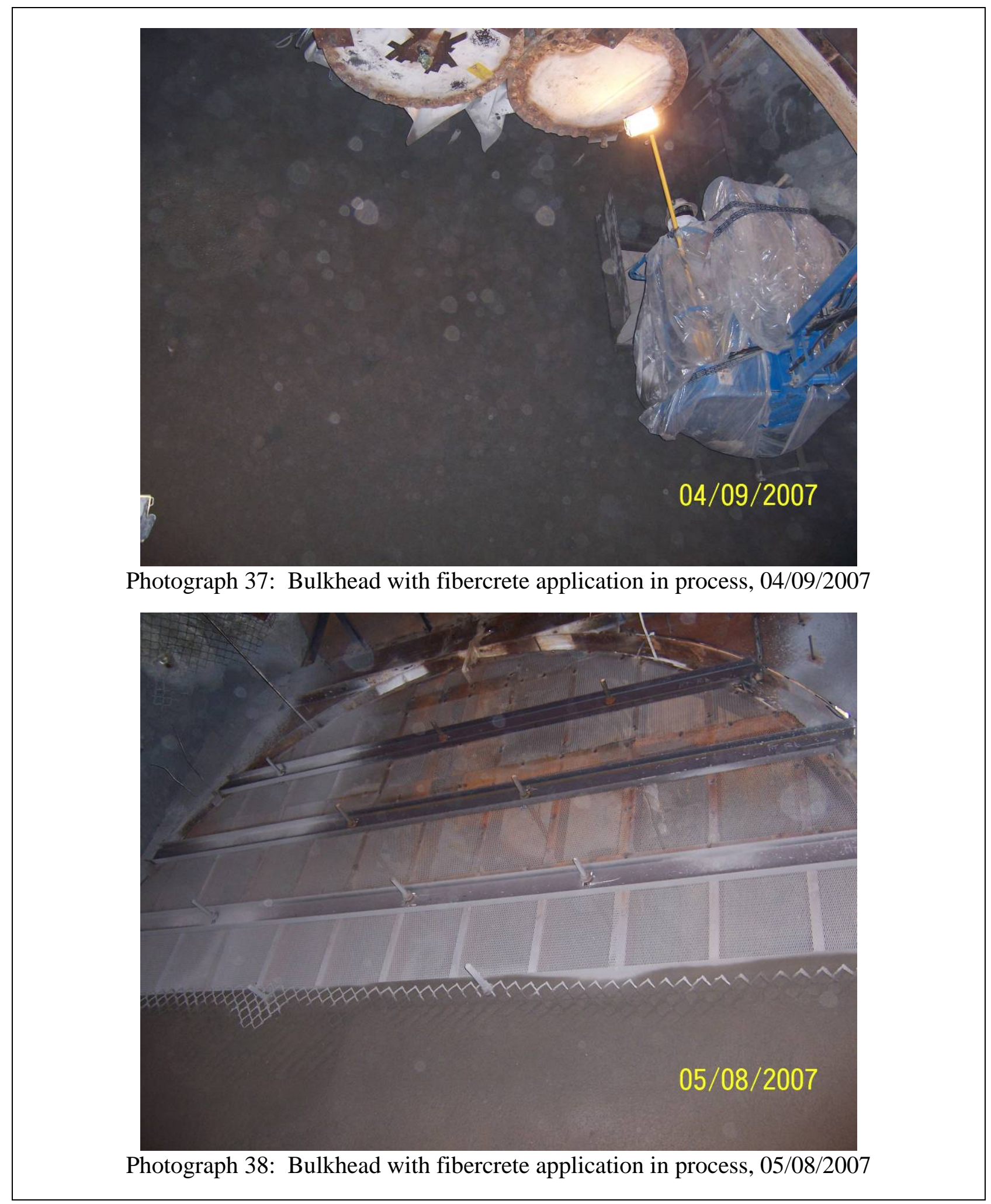




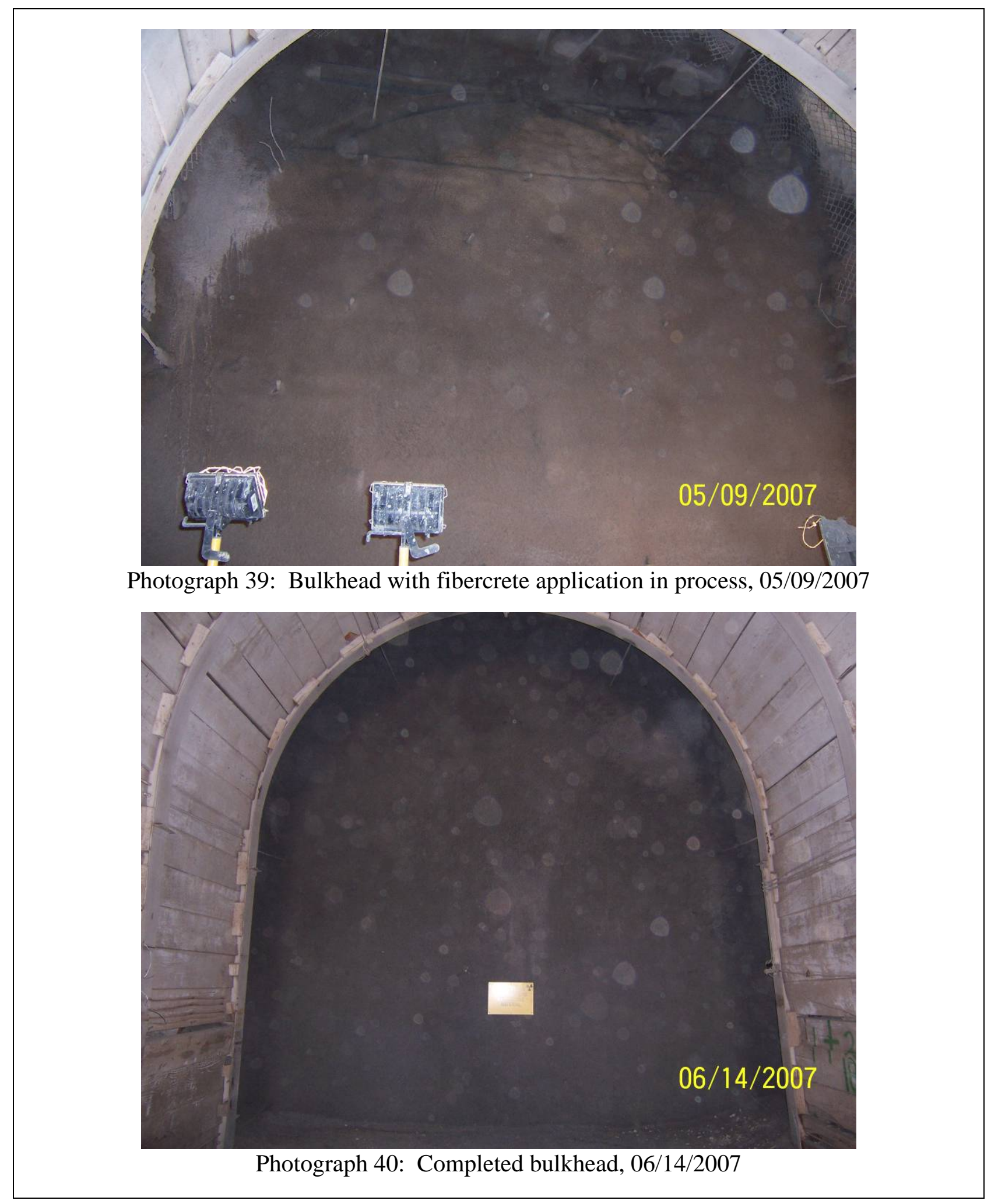




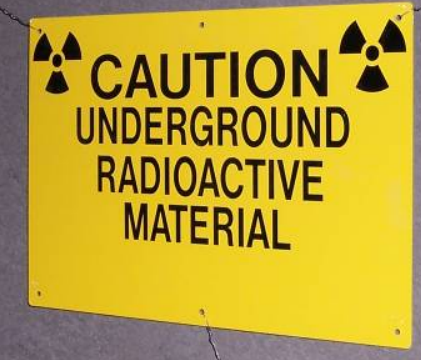

Photograph 41: Underground Radioactive Material sign affixed to bulkhead, 06/14/2007

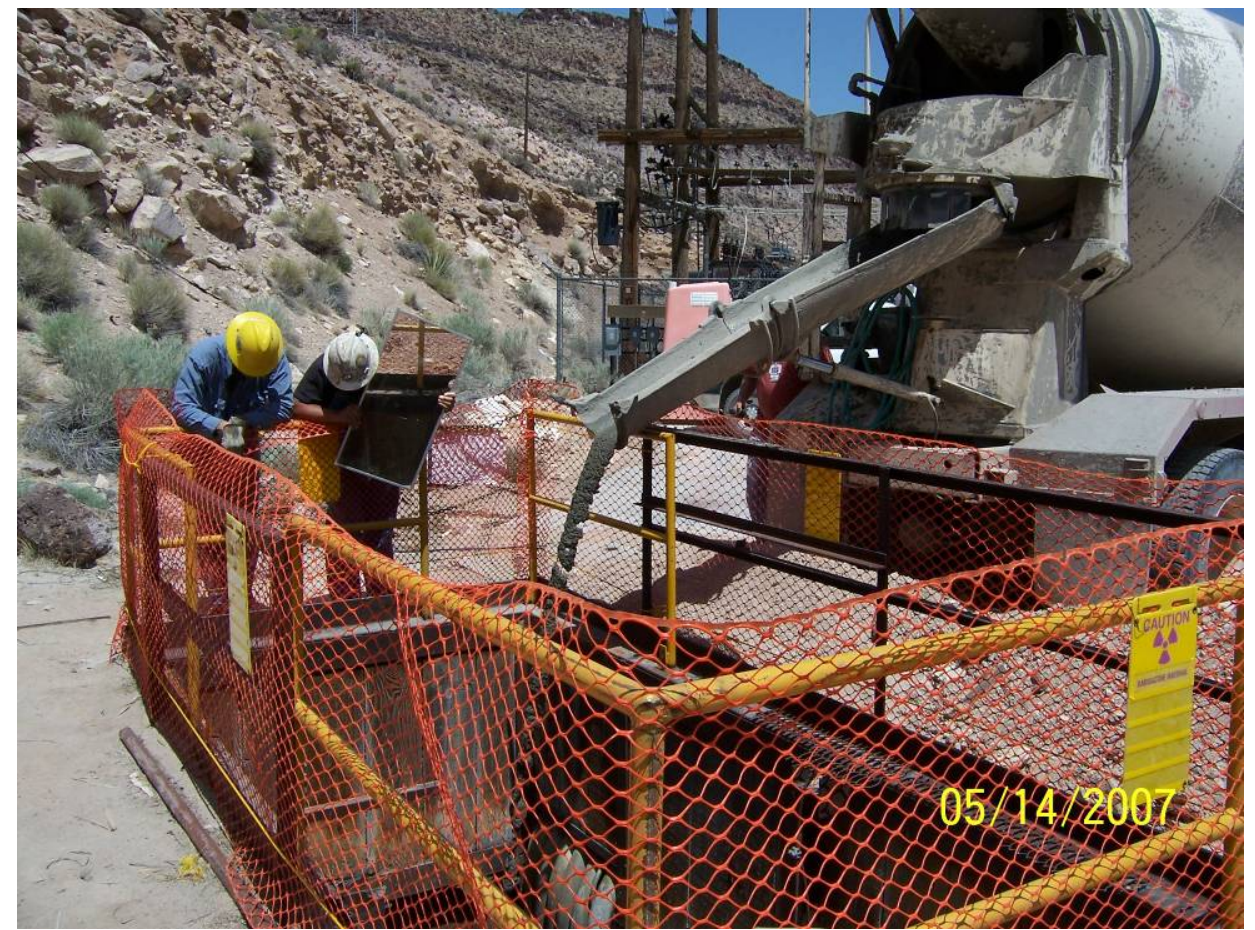

Photograph 42: Grout pour into vent raise, 05/14/2007 


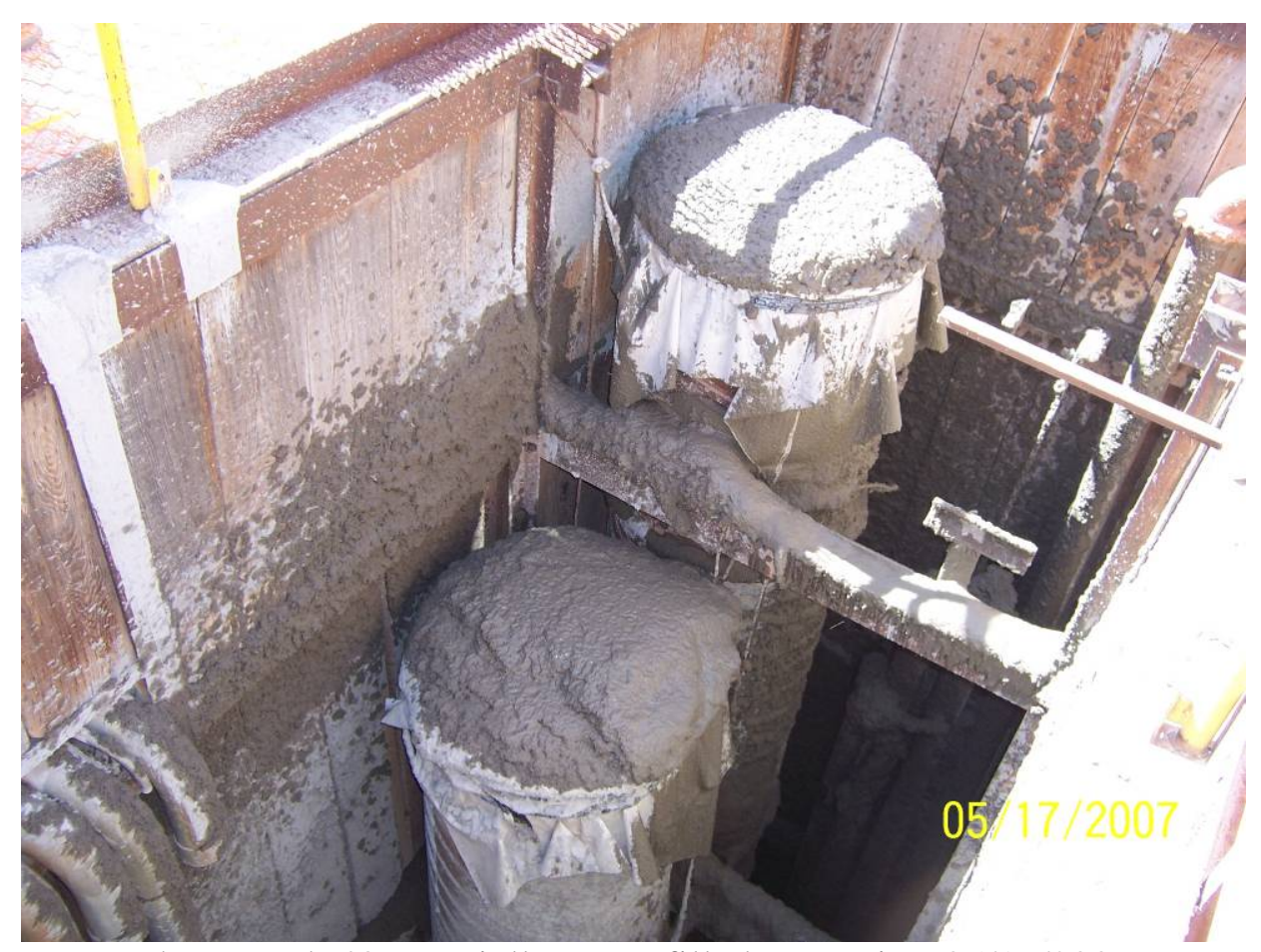

Photograph 43: Partially grout-filled vent raise, 05/17/2007

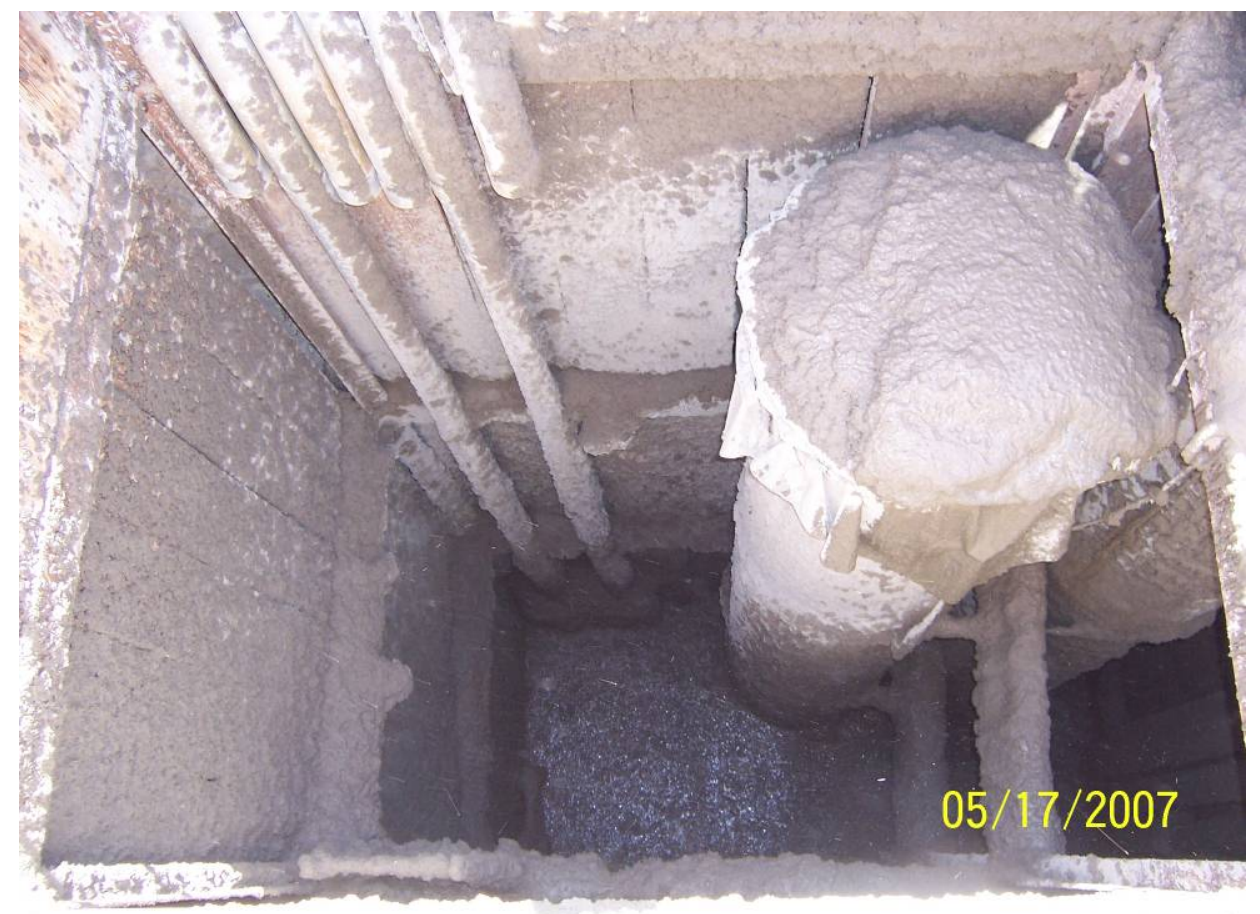

Photograph 44: Partially grout-filled vent raise, 05/17/2007 


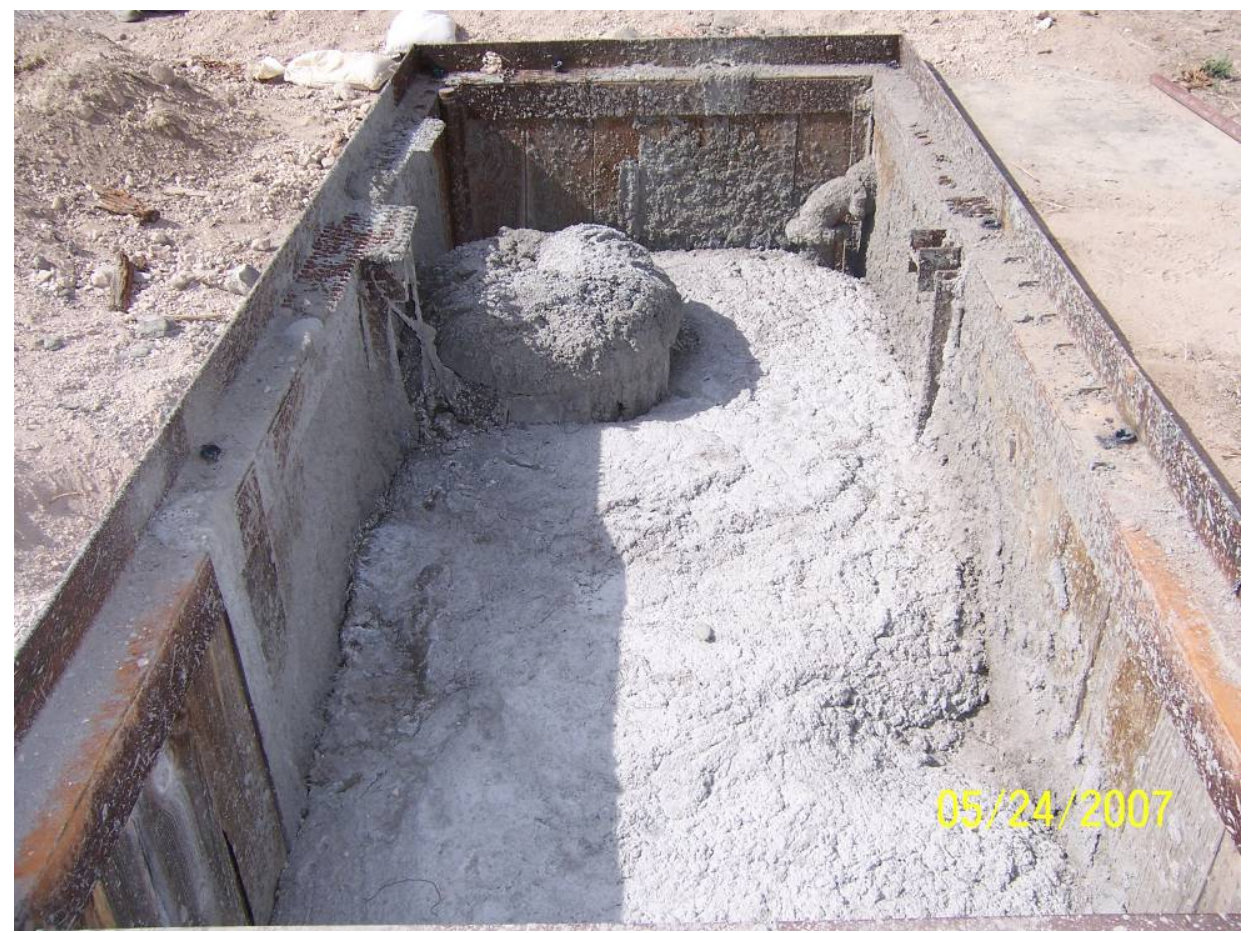

Photograph 45: Vent raise almost filled with concrete, 05/24/2007

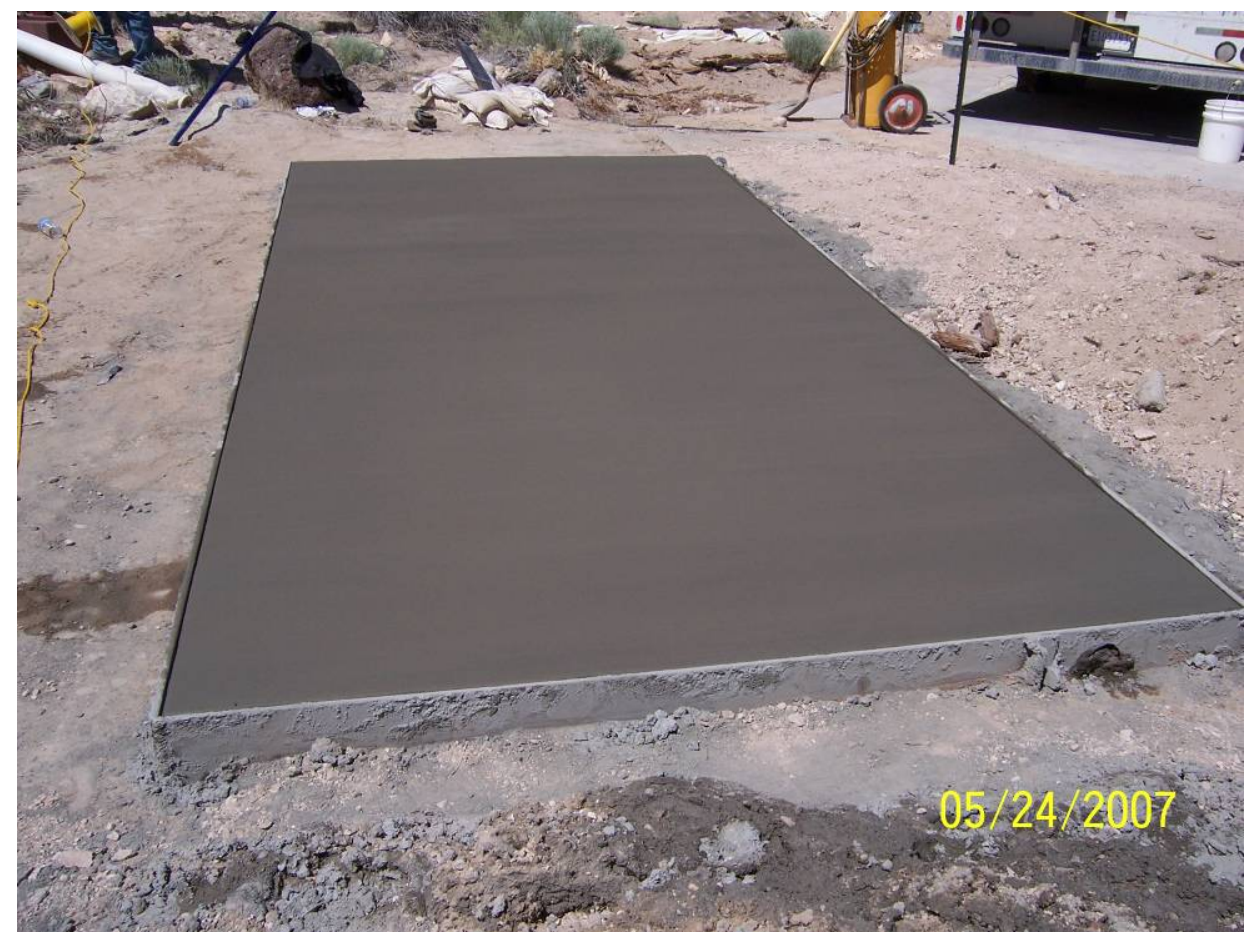

Photograph 46: Vent raise completely filled and finished, 05/24/2007 
T-Tunnel Closure Report Section: Appendix B

Revision: 0

Date: August 2008

THIS PAGE INTENTIONALLY LEFT BLANK 
T-Tunnel Closure Report

Revision: 0

Date: August 2008

APPENDIX C

\section{T-TUNNEL FACILITY CLOSURE PRESSURE TEST FORMS}


T-Tunnel Closure Report

Section: Appendix C

Revision: 0

Date: August 2008

THIS PAGE INTENTIONALLY LEFT BLANK 


\section{Hydrostatic Pressure Testing on U12t GSD Grout Pipe}

\section{Line Network Sample Pipe Line Network (1 of 4) 2"Line}

Work Steps (Locate this table and work steps in each work steps location where Pressure Testing is required)

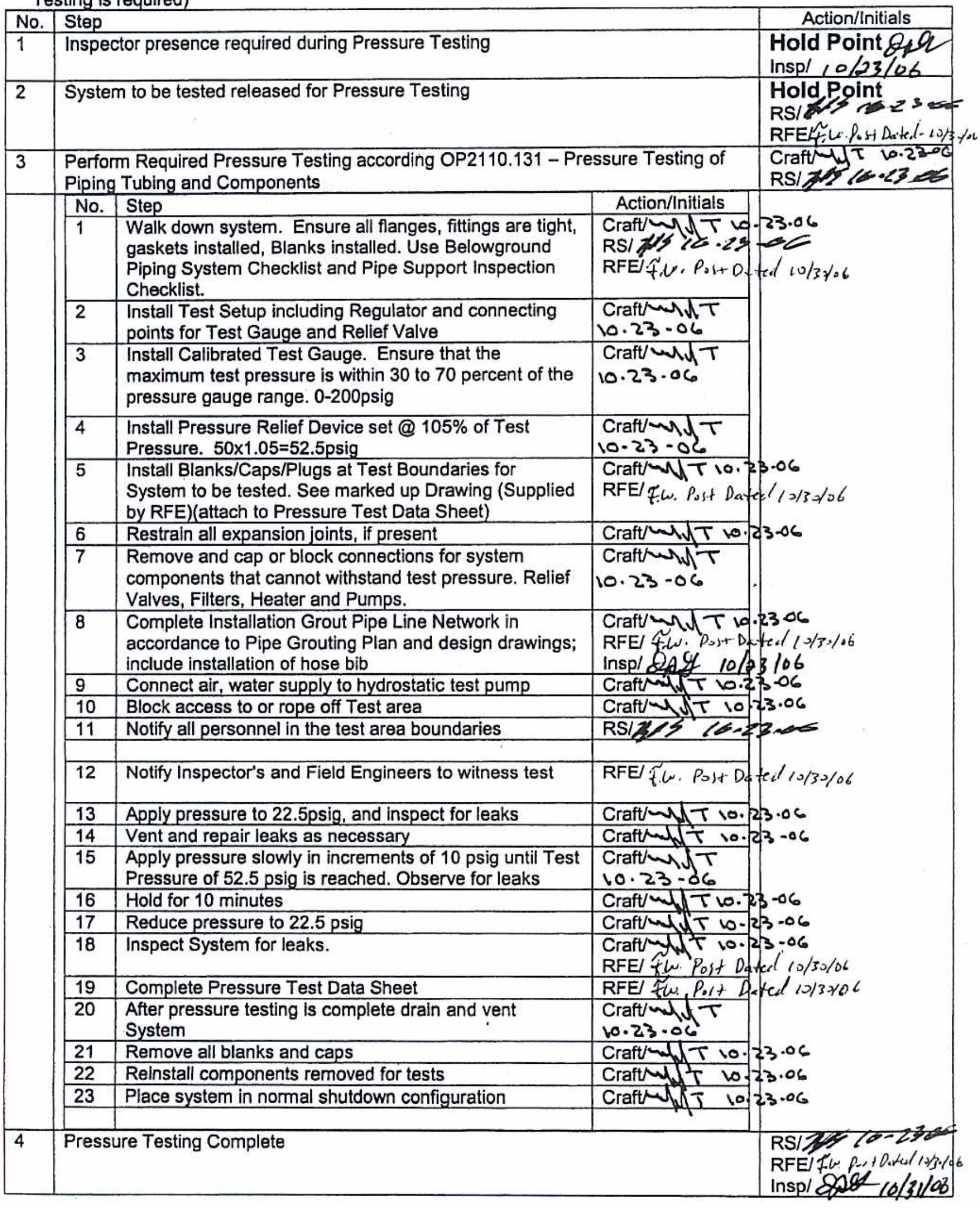


Pressure Test Data Sheet

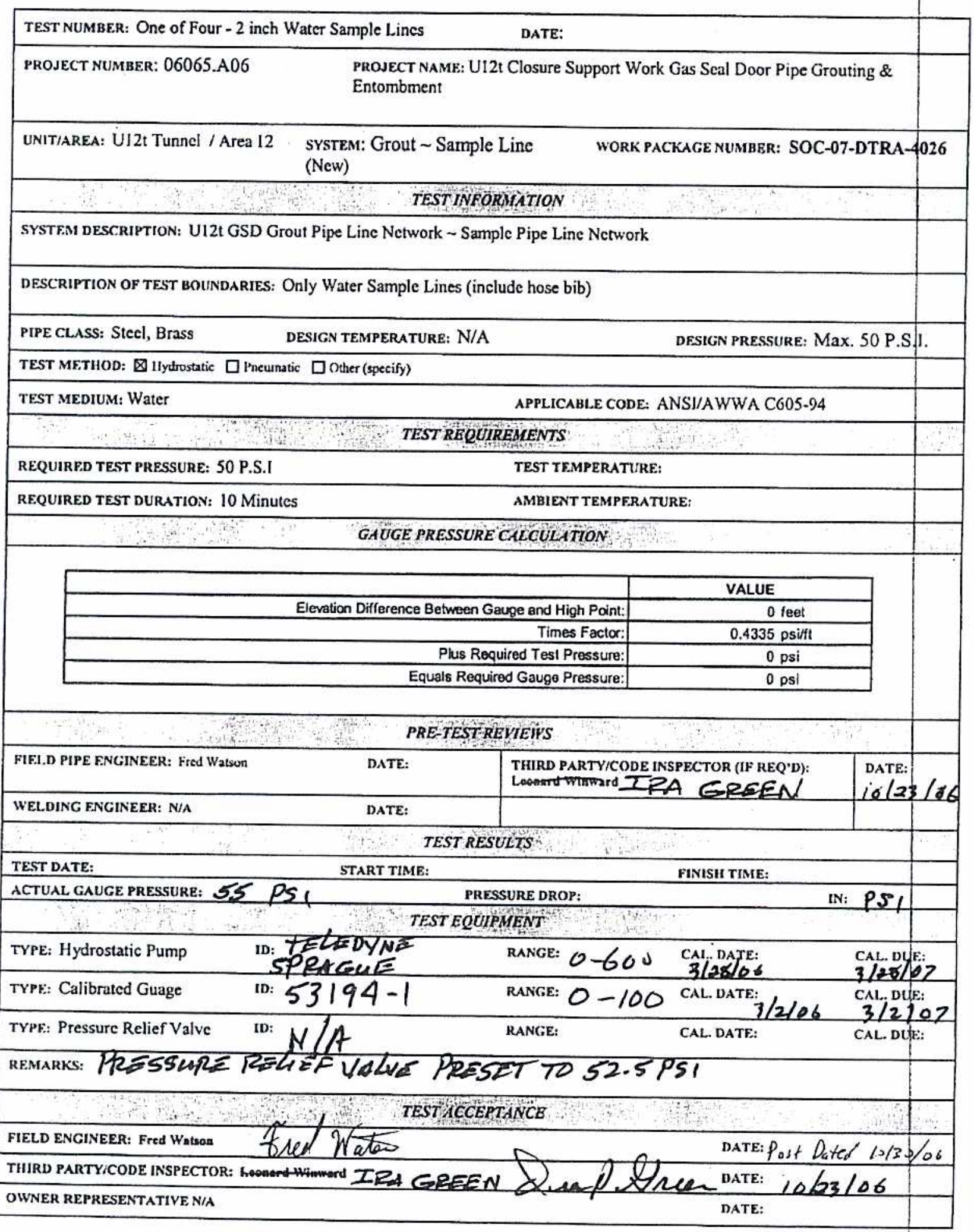




\section{Hydrostatic Pressure Testing on U12t GSD Grout Pipe Line Network Sample Pipe Line Network (2 of 4) 2"Line}

Work Steps (Locate this table and work steps in each work steps location where Pressure

Testing is required)

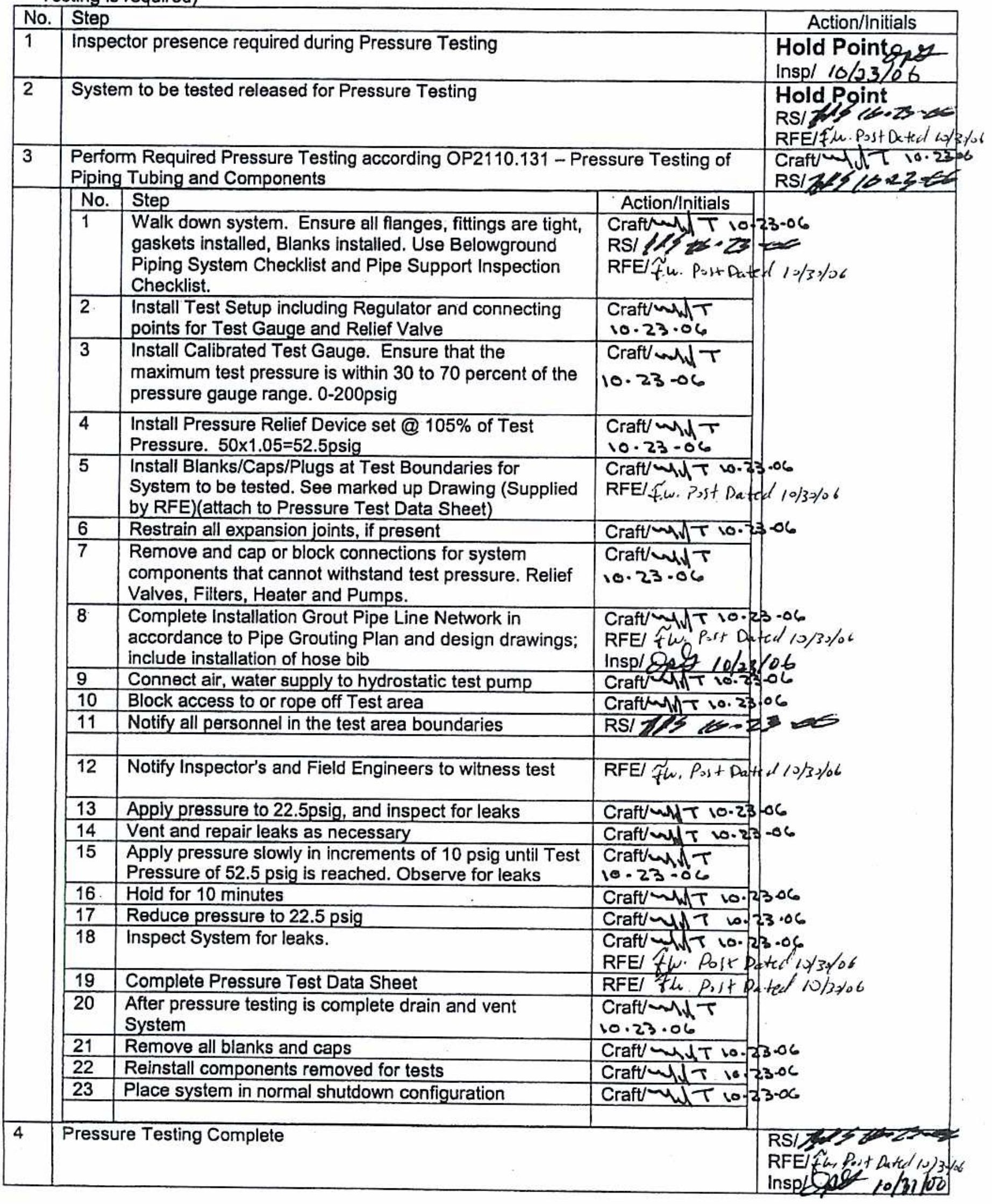


Pressure Test Data Sheet

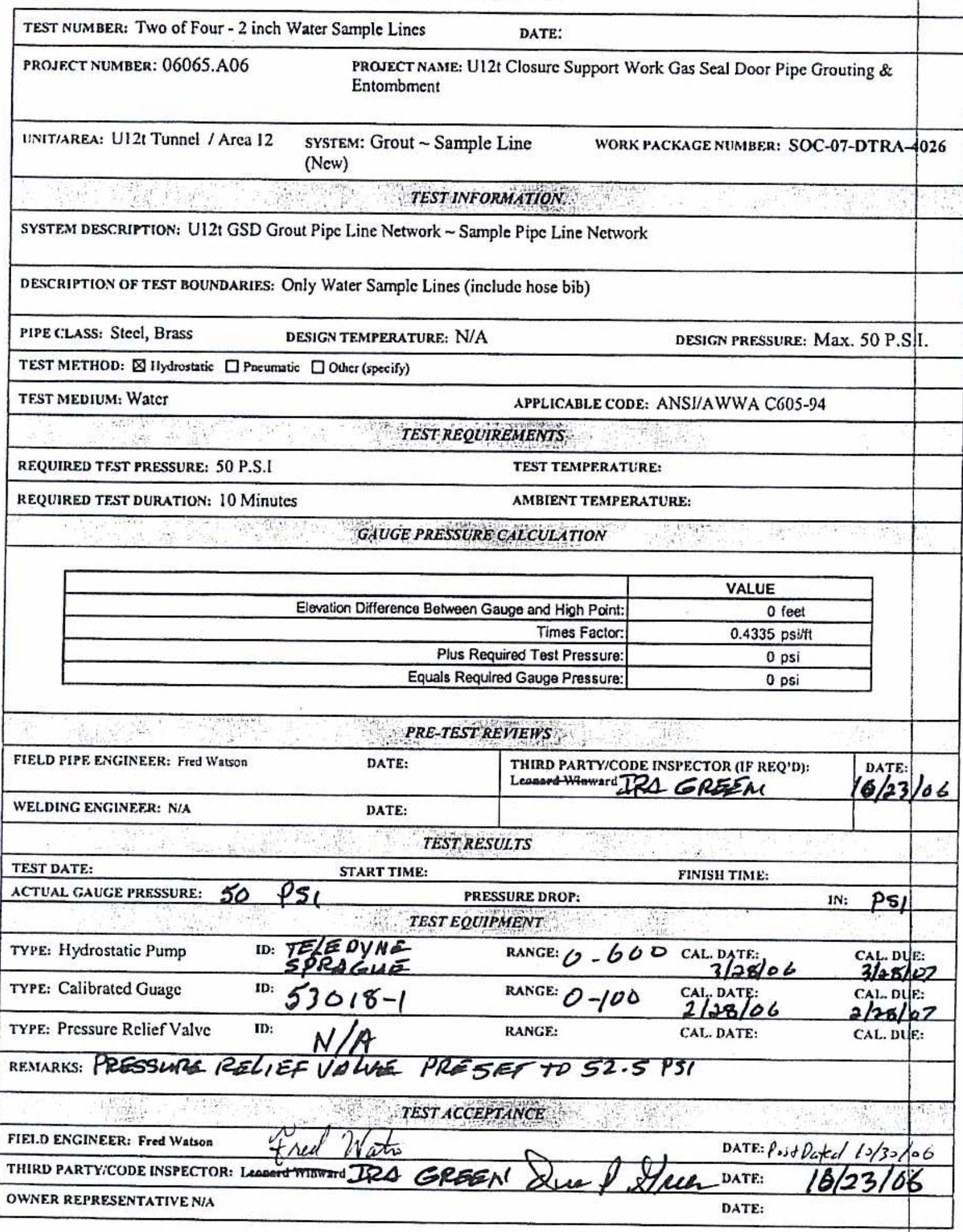




\section{Hydrostatic Pressure Testing on U12t GSD Grout Pipe Line Network Sample Pipe Line Network (3 of 4) 2"Line}

Work Steps (Locate this table and work steps in each work steps location where Pressure

Testing is required)

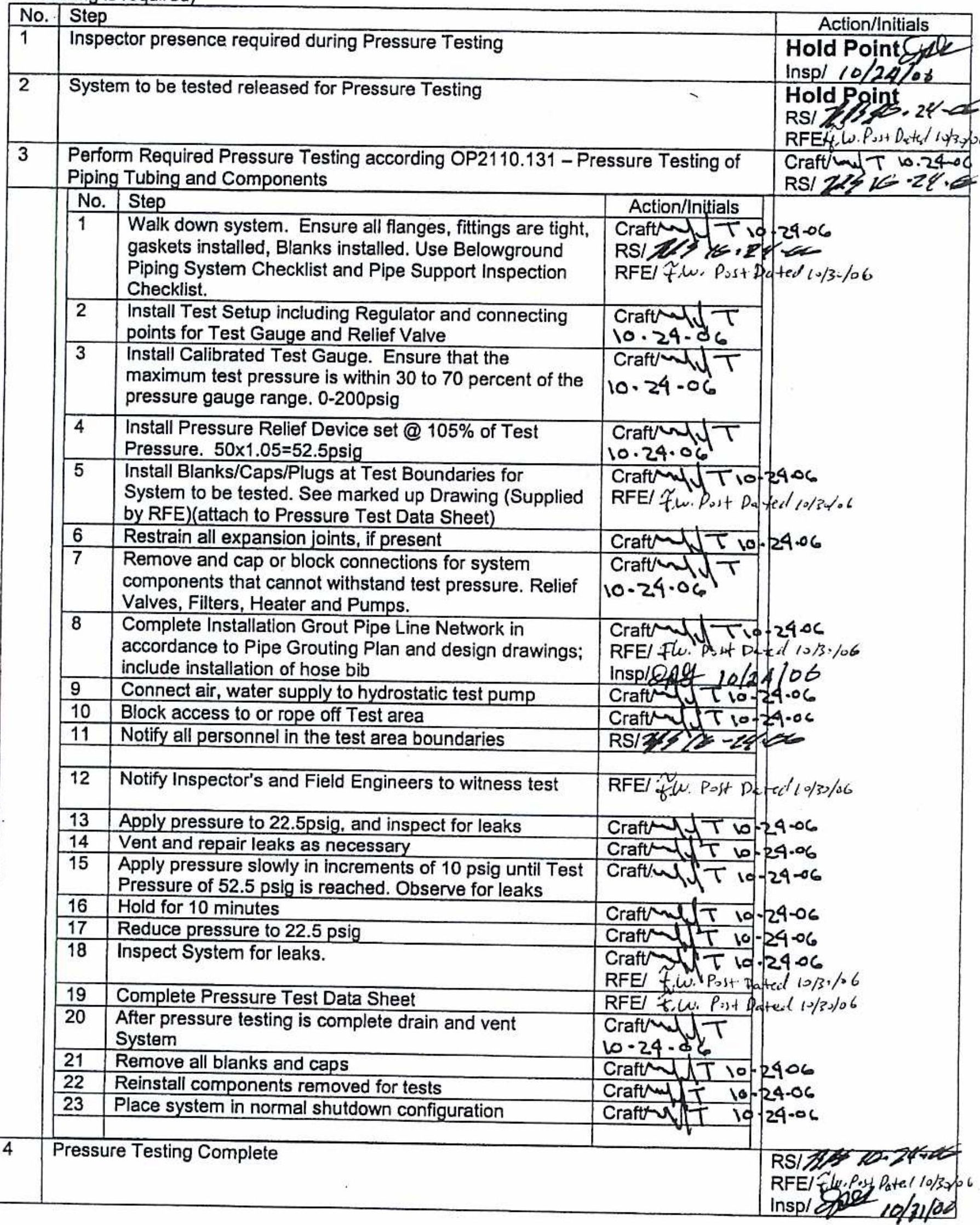


Pressure Test Data Sheet

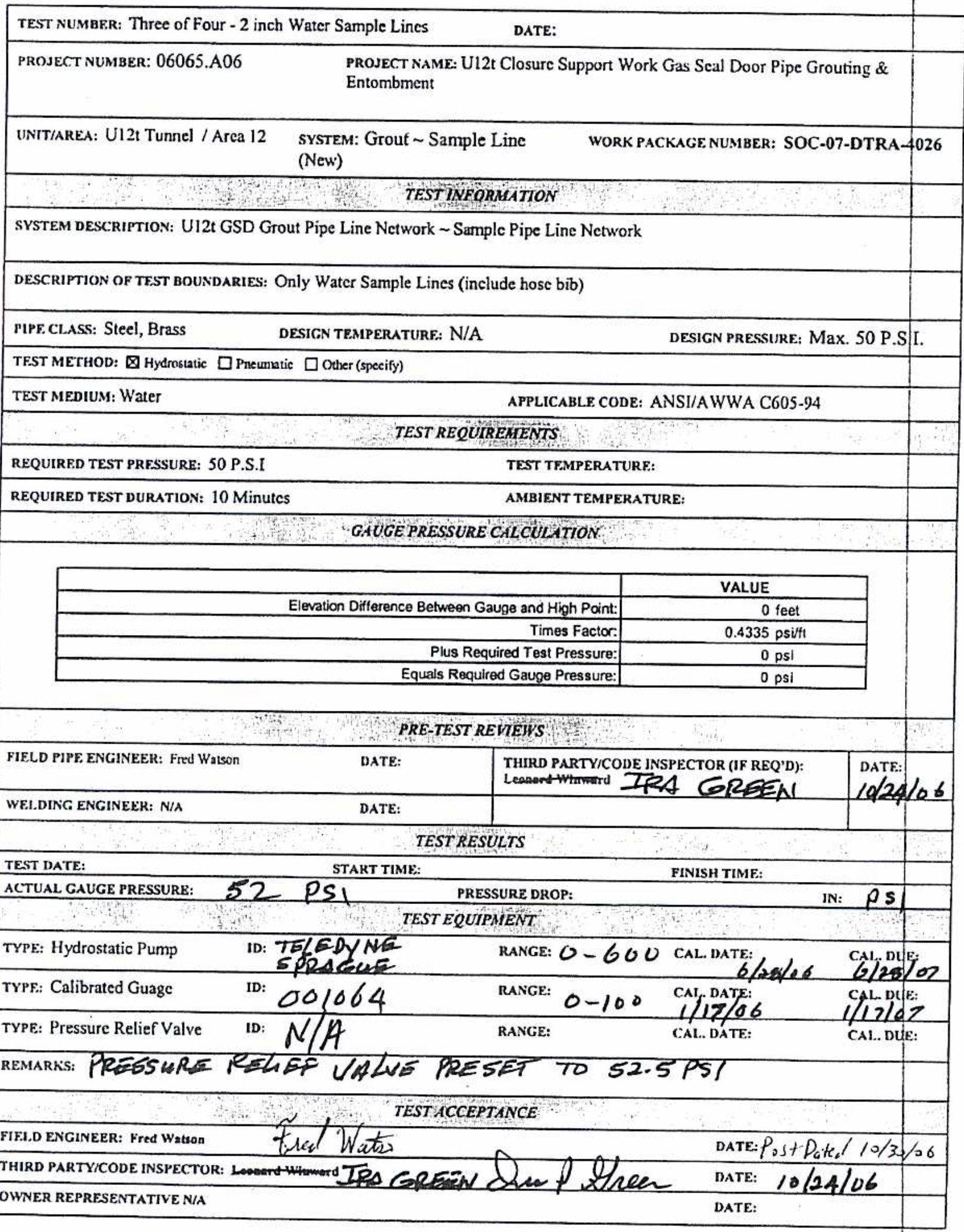




\section{Hydrostatic Pressure Testing on U12t GSD Grout Pipe Line Network Sample Pipe Line Network (4 of 4) 2"Line}

Work Steps (Locate this table and work steps in each work steps location where Pressure

Testing is required)

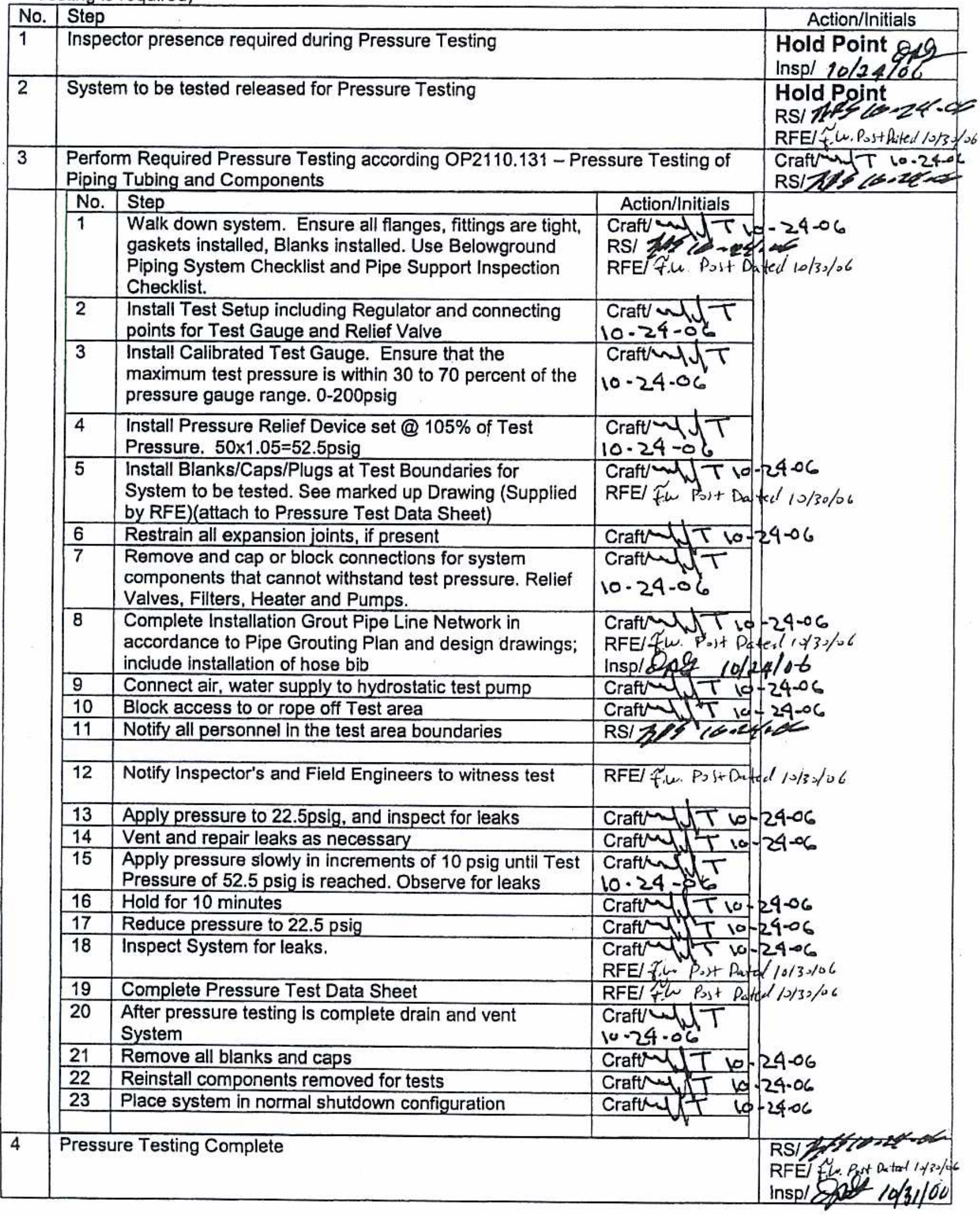




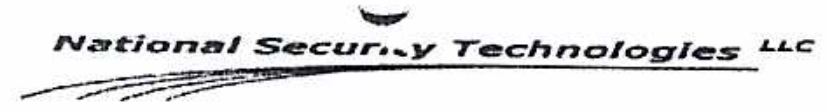

Pressure Test Data Sheet

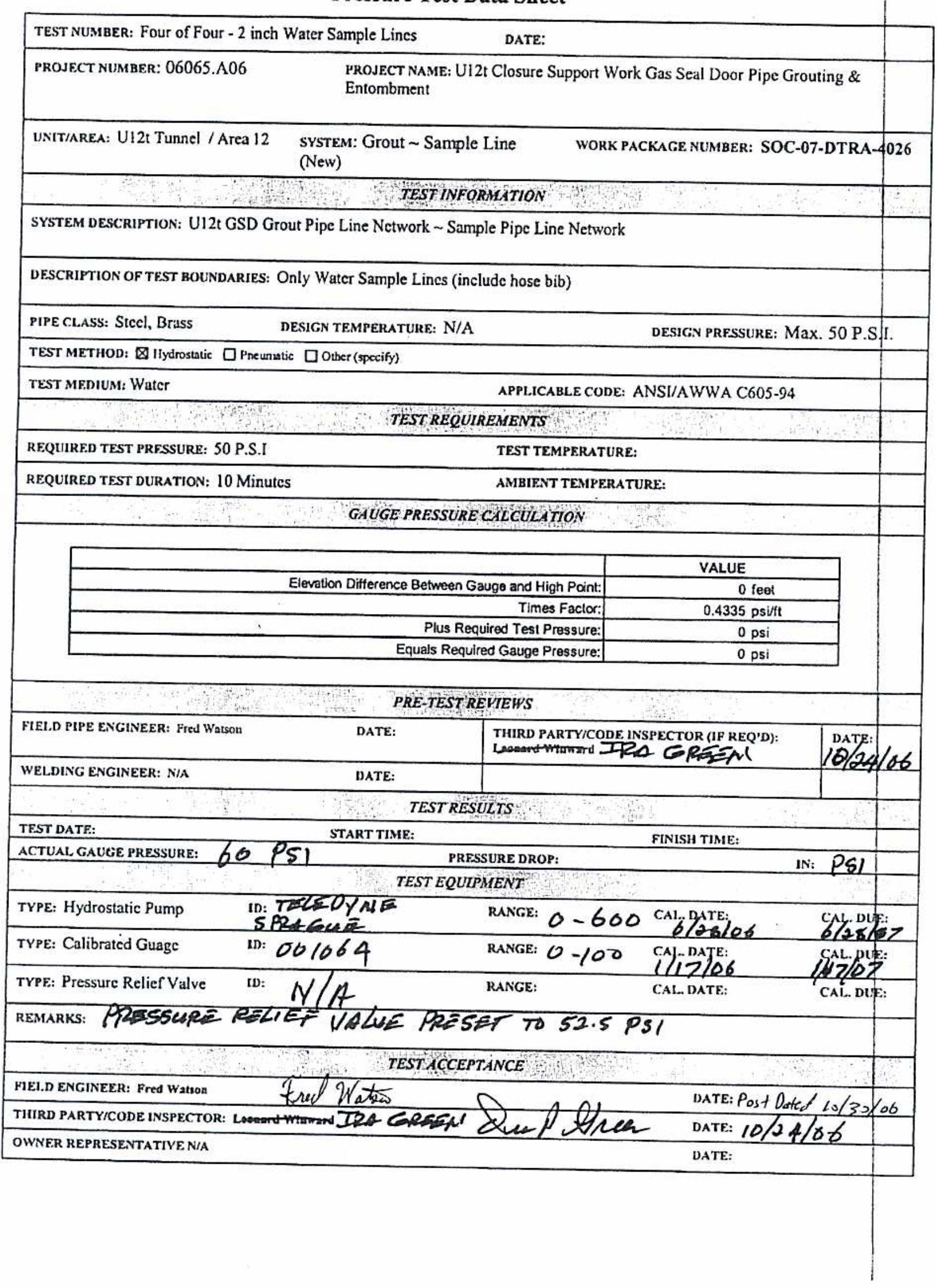




\section{Natoma \\ Hydrostatic Pressure Testing on U12t GSD Grout Pipe Line Network Sample Pipe Line Network (1 of 4"Line}

Work Steps (Locate this table and work steps in each work steps location where Pressure Testing is required)

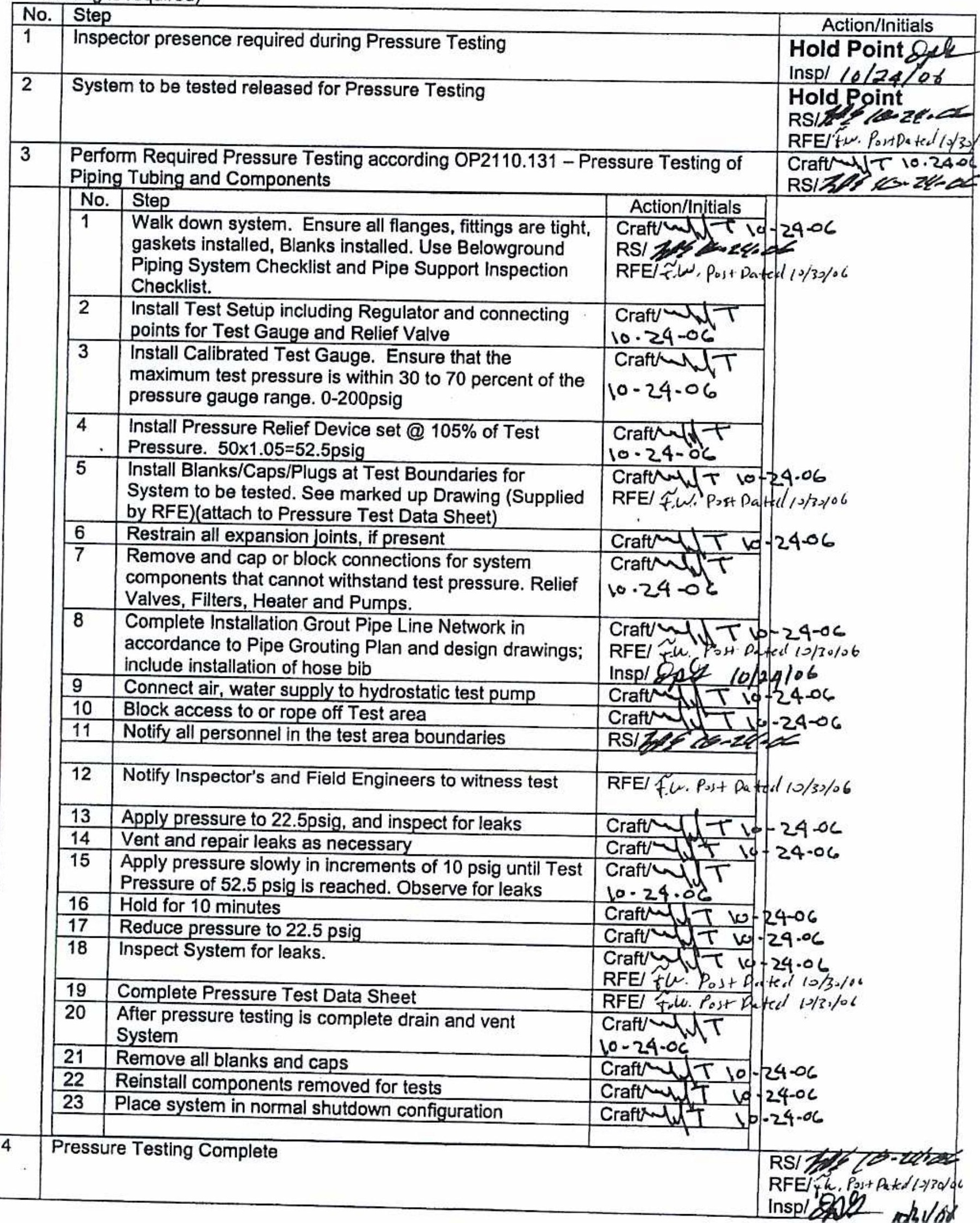




\section{Pressure Test Data Sheet}

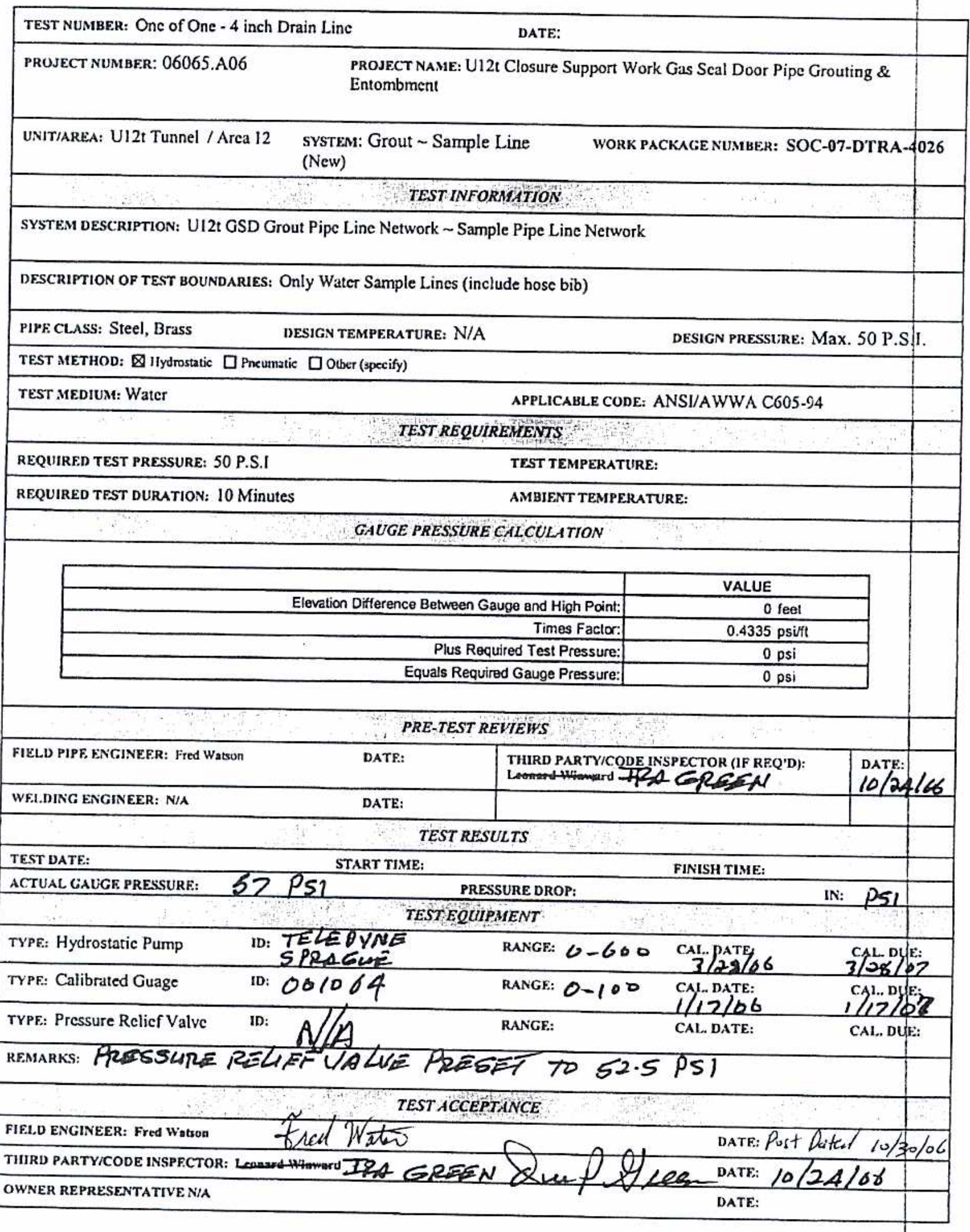


NSTec

Concrete Pour Card

\begin{tabular}{|c|c|c|c|c|c|c|}
\hline \multicolumn{4}{|l|}{ RECORD NUMBER: A-12-0005 } & \multicolumn{3}{|c|}{ DATE: January 10, 2007} \\
\hline PROJECT NUMBER 06065.A06 & \multicolumn{6}{|c|}{ PROJECT NAME: : Concrete/Grout U12t Tunnel Drain \& Sample Lines } \\
\hline CONTRACTOR NAME: N/A & \multicolumn{6}{|c|}{ POUR DATE: January 11,2007} \\
\hline POUR IDENTIFICATION: Area 12, l & \multicolumn{6}{|c|}{ POUR QUANTITY: 6 yrds } \\
\hline SYSTEM: & \multicolumn{6}{|c|}{ WORK PACKAGE: 4026} \\
\hline REFERENCE DOCUMENT NO. & REV. NO. & \\
\hline JS-012-U12t-M15 & 0 & \multicolumn{5}{|c|}{ REMARKS (list applicable FCR, DCN, etc.) } \\
\hline \multicolumn{7}{|c|}{ ALLOWABLE SLUMP RANGE: 4 inches } \\
\hline DESIGN STRENGTH: $5,000 \mathrm{psi}$ & \multicolumn{6}{|c|}{ MAXIMUM AGGREGATE SIZE: $3 / 4$ inch } \\
\hline PLACING METHOD: LHD bucket & \multicolumn{6}{|c|}{ ALLOWABLE POUR RATE: N/A } \\
\hline CURING METHOD: None & \multicolumn{6}{|c|}{ FINISH: None } \\
\hline \multicolumn{2}{|c|}{ PRE-PLACEMENT CHECKLIST } & INITIAL & \multirow[t]{2}{*}{ DATE } & \multirow[t]{2}{*}{ INITIAL } & DATE & N/A \\
\hline \multicolumn{2}{|c|}{ Subgrade (top of previoul (ancrete placemest) } & t.w, & & & & $\square$ \\
\hline \multicolumn{2}{|c|}{ Formwork (sand bags) } & f.w. & & & & $\square$ \\
\hline \multicolumn{2}{|l|}{ Line and grade } & & & & & N/A \\
\hline \multicolumn{2}{|l|}{ Reinforcing } & & & & & Q \\
\hline Embedded items: & & & & & & $\square$ \\
\hline 2 inch steel Pipe \& Valve ( $t u t a /$ of & four) & $\widetilde{t} \cdot \omega$. & & & & $\square$ \\
\hline 4 inch steel Pipe \& Valve ( $t v t c$ ) of & in ) & t.w. & & & & $\square$ \\
\hline & & & & & & Q \\
\hline & & & & & & Q \\
\hline Inside formwork cleanup & & & & & & 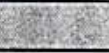 \\
\hline Other (specify): & & & & & & $\nabla$ \\
\hline Other (specify): & & & & & & $\otimes$ \\
\hline Release for placement & & Fu. & & & & $\sqrt{25}$ \\
\hline FIELD ENGINEER: FRED WATSON & trul Wats & & & ATE: $1 / 1$ & 107 & \\
\hline POST-PLACEMENT CUR & NG CHECKLIST & INITIAL & DATE & INITIAL & DATE & N/A \\
\hline Proper finish applied - None & & & & & & $\otimes$ \\
\hline Proper curing method applied & & & & & & 凶 \\
\hline Required hot or cold weather protection pr & vided & & & & & 凶 \\
\hline Cure temperature maintained & & & & & & N/A \\
\hline Other (specify): & & & & & & 凶 \\
\hline Other (specify): & & & & & & 凶 \\
\hline Formwork removed Sand bayss to re & hain & Th. & & & & $\square$ \\
\hline COMMENTS: & & & & & & \\
\hline FIELD ENGINEER: FRED WATSON & Trud Wato & & & TE: $1 / 1$ & & \\
\hline
\end{tabular}




\section{NSTec}

\section{Concrete Pour Card}

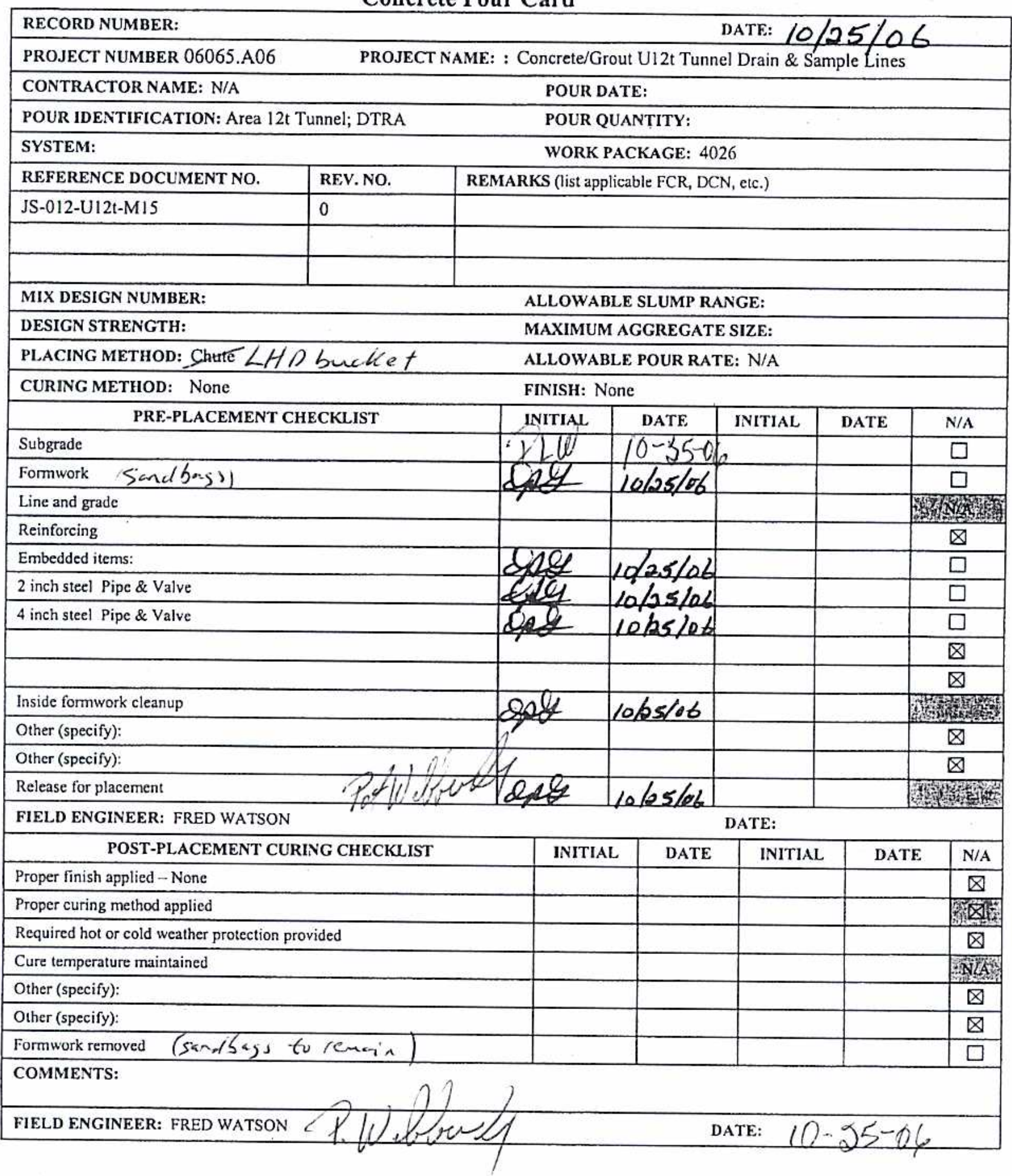




\section{APPENDIX D}

\section{FACILITY CLOSURE PLAN FOR N- AND T- TUNNELS, AREA 12, NEVADA TEST SITE}


T-Tunnel Closure Report Section: Appendix D

Revision: 0

Date: August 2008

THIS PAGE INTENTIONALLY LEFT BLANK 


\section{FACILITY CLOSURE PLAN FOR N- AND T-TUNNELS AREA 12 NEVADA TEST SITE}

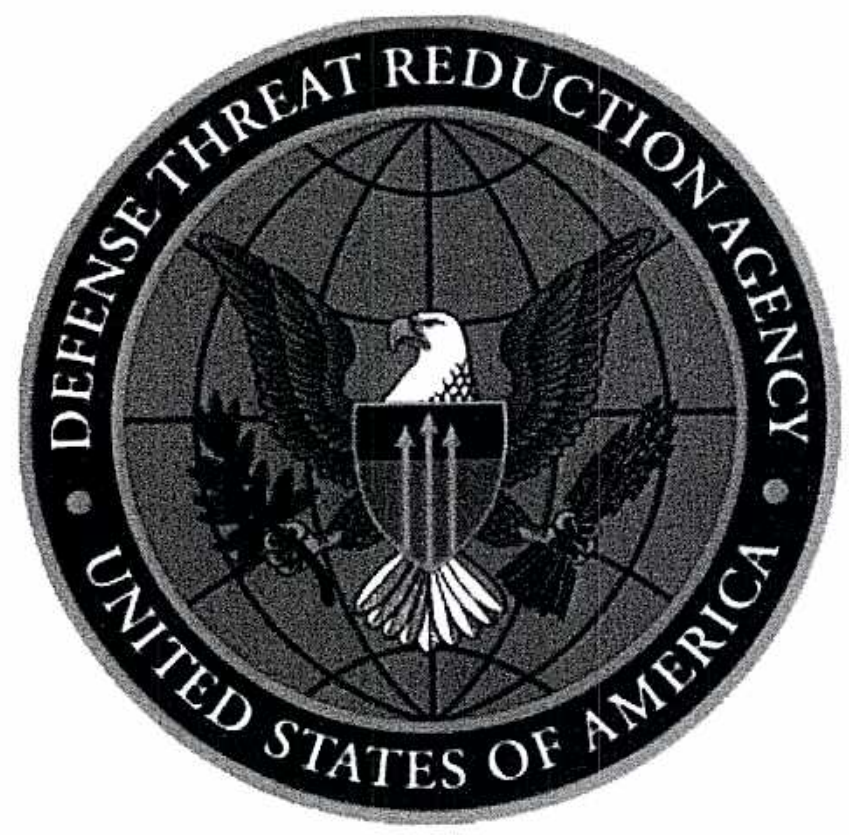

November 2003 


\title{
Facility Closure Plan $\mathrm{N}$ - and $\mathrm{T}$ - Tunnels Area 12 Nevada Test Site
}

\author{
Prepared by \\ Defense Threat Reduction Agency \\ Nevada Operations Section \\ Mercury, Nevada
}

November 2003 


\section{Facility Closure Plan \\ $\mathrm{N}$ - and T-Tunnels \\ Area 12 \\ Nevada Test Site}

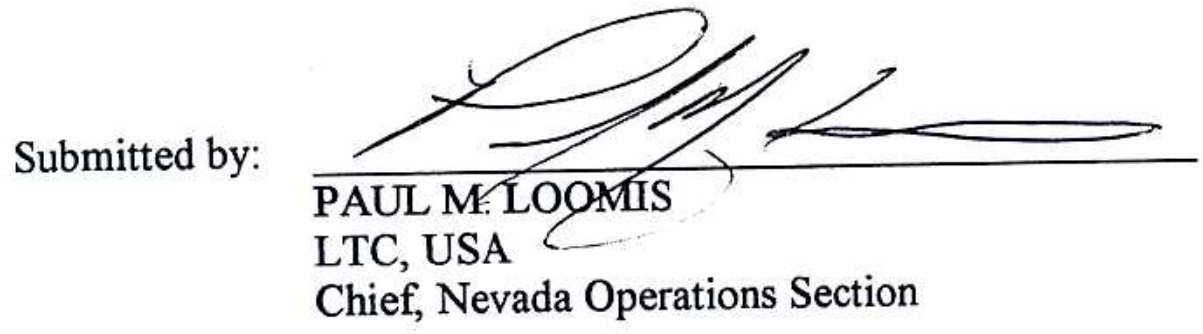

Date: 2 DecOS 


\subsection{Introduction}

This Facility Closure Plan (Plan) has been prepared by the Defense Threat Reduction Agency (DTRA) Environmental, Safety, and Health Group at the Nevada Test Site (NTS). This Plan provides background information about N-Tunnel and T-Tunnel, describes the containment structures (plugs), and outlines the basic procedures for closure of the accessible areas of the tunnels. The Plan does not address short or long-term monitoring of water impounded behind the plugs in the tunnels. This Plan excludes the muckpiles and ponds used to support the tunnel complexes. The muckpiles and ponds will be closed in accordance with (IAW) requirements of the Federal Facility Agreement and Consent Order.

\subsection{Purpose}

The purpose is to close the accessible tunnel areas between the portals and the Gas Seal Plugs (GSP) at N-Tunnel and between the portal and the Gas Seal Door (GSD) at T-Tunnel and turn ownership and control of these two facilities over to the National Nuclear Security Administration/Nevada Site Office.

\subsection{Scope}

Scope for the N-Tunnel Facility closure includes:

- Plug the sample collection lines that penetrate the GSPs in the U12n. Main Drift and the U12n. Extension Drift.

- Place a concrete sarcophagus on the portal side of the GSPs to entomb the exposed portions of the sample collection lines and protect them from potential rockfall.

- Close the GSD in the U12n. Main Drift and weld the door to the frame.

- Install a blind flange on each end of the U12n. Extension Drift GSD crawl tube and stem with groutcrete.

- Remove:

- Oil filled transformer 
- Fire extinguishers

- Hydraulic fluid

- Asbestos backboards holding electrical panels

- Fluorescent light fixtures

- Construct a full tunnel cross-section shotcrete bulkhead near the portal to prevent unauthorized tunnel access.

Scope for the T-Tunnel Facility closure includes:

- Plug the sample collection lines that penetrate the GSD and the GSP in the U12t. Main Drift.

- Place a concrete sarcophagus on the portal side of the GSD to entomb the exposed portions of the sample collection lines and protect them from potential rockfall.

- Remove ventilation line from the vent raise and backfill the vent raise.

- Remove:

- Oil filled transformer

- Fire extinguishers

- Any asbestos insulation from the tunnel water line

- Fluorescent light fixtures

- Construct a full tunnel cross-section shotcrete bulkhead near the portal to prevent unauthorized tunnel access. 


\subsection{Facility Description}

$\mathrm{N}$ and $\mathrm{T}$ Tunnel are both located in Area 12 of the NTS. Figure 1 indicates the location of the tunnels within the NTS. The N-Tunnel complex has two parallel access drifts; the U12n. Main drift and the U12n. Extension drift. Each N-Tunnel access drift contains two Nuclear Weapons Effects Tests (NWET) containment structures; a Gas Seal Plug (GSP) and a Gas Seal Door (GSD). The T-Tunnel complex has a single access drift with a GSP and a GSD.

The GSPs and the GSDs were designed and engineered to prevent radioactive gases from escaping to the atmosphere following a NWET. The GSPs are located approximately 2,000 feet from the portal. The GSD in the U12n. Main drift is located approximately 1,700 feet from the portal. The GSD in the U12n. Extension drift is located approximately 1,900 feet from the portal.

\subsection{History}

N- and T-Tunnel were used for NWET and were operational between 1964 and 1993. The tunnels were excavated horizontally into the volcanic rocks of Rainier Mesa. Groundwater discharged from both tunnels to evaporation ponds throughout most of their operational life. TTunnel was mothballed in 1993 by sealing the U12t. Main GSP and the U12T. Main GSD. NTunnel was mothballed in 1994 by sealing the U12n. Main drift GSP and the U12n. Extension drift GSPs. The objectives of the mothballing were:

- Preservation of the tunnel for resumption of testing under the Nuclear Treaties Safeguards.

- Eliminate radioactive water (tritium) and air (tritium and natural radon) emissions, consistent with the Department of Energy waste minimization policy, which allowed for tritium decay in transit in confined ground water.

- Prevent unauthorized access.

- Economic considerations: (i.e. eliminate waste water treatment-disposal costs, eliminate annual cost for tunnel; maintenance, delay electrical upgrade requirements until reopening. 


\subsection{Plug Design and Construction}

The Gas Seal Plugs (GSPs) were designed to withstand the direct blast effects of an underground NWET and remain leaktight under potential high-pressure loading of 500 pounds per square inch (psi) and a temperature of $500^{\circ} \mathrm{F}$. The GSPs are keyway-type plugs made of positive expansion (negative contraction) concrete and groutcrete placed monolithically. The plugs are nominally $18 \mathrm{ft}$. long with one asymmetrical keyway (approximately $10 \mathrm{ft}$. wide by $5 \mathrm{ft}$. deep) around the entire periphery. A ring of 18 to 30 pre-grout holes, each $26 \mathrm{ft}$. to $40 \mathrm{ft}$. deep, were drilled in the bottom of the keyway and the holes were pressure grouted until a minimum 250 phi was maintained for five minutes. Two rings of post-grout holes were pressure grouted subsequent to the monolithic placement of the concrete and groutcrete plugs. The concrete and groutcrete had minimum unconfined compressive strengths of $4000 \mathrm{psi}$. The tunnels were pressurized to leak test the plugs and surrounding rock. The plug area was pressure grouted to seal any leaks during pressurization test.

The design criteria for the GSDs were not as demanding as that required for the GSPs. The Gas Seal Doors (GSDs) were designed to remain leaktight under a pressure loading of 75 psi and a temperature of $75^{\circ} \mathrm{F}$. The GSDs are pre-fabricated, single leaf doors with steel jambs. The GSDs are keyed into the tunnel and pressure grouted similar to the GSPs. The GSDs can be considered a secondary containment feature. 


\subsection{Tunnel Closure}

\section{$3.1 \quad$ N-Tunnel}

All fire extinguishers, hydraulic fluid, one oil filled non-PCB transformer, asbestos backboards, and fluorescent light fixtures will be removed from the tunnel.

The sample collection lines in each GSP, U12n. Main drift and U12n. Extension drift, will be fully grouted with an epoxy compound or cement grout. The valves will be closed, pressure gauges and water sample ports removed, and the lines capped. A concrete sarcophagus will be built on the portal side of each GSP. The sarcophagus will cover the exposed portions of the sample collection lines to protect from potential rockfall.

The U12n. Main drift GSD will be closed and welded shut. The U12n. Extension GSD crawltube, 36-inch diameter by 12-foot long, access through the GSD to the GSP will be sealed on each end with a blind flange. The crawl-tube will be stemmed full with grout.

Temporary tunnel ventilation equipment will be removed from the portal area.

At the U12n. Main drift portal, the gate, steel sets, lagging, and loose rock, will be removed to competent ground under the brow. A shotcrete bulkhead will be constructed at that point to prevent unauthorized entrance to the tunnel.

At the U12n. Extension drift portal, the gate and frame will be removed. A shotcrete bulkhead will be constructed in competent ground under the brow to prevent unauthorized entrance to the tunnel.

\section{$3.2 \quad$ T-Tunnel}

All fire extinguishers, oil filled non-PCB transformer, potential asbestos water line insulation, and fluorescent light fixtures will be removed from the tunnel.

The four sample collection lines that penetrate the U12t. Main drift GSD, two for water sample collection at the GSD and two that extend through the GSP for water sample collection inside the GSP, will be fully grouted with an epoxy compound or cement grout. The valves will be closed, pressure gauges and water sample ports removed, and lines capped. A concrete sarcophagus will be built on the portal side of the GSD. The sarcophagus will cover the exposed portions of the sample collection lines to protect from potential rockfall. 
Temporary tunnel ventilation equipment will be removed from the portal area. Ventilation ducts will be removed from the vent raise between the tunnel and the compressor/blower pad. The vent raise will be backfilled to the surface with native soil, or a combination of groutcrete and native soil.

At the portal, steel sets, lagging, and loose rock, will be removed to competent ground under the brow. A shotcrete bulkhead will be constructed at that point to prevent unauthorized entrance to the tunnel.

\subsection{Material, Equipment, and Waste Disposition}

All material, equipment, and waste removed from the tunnel will be dispositioned IAW governing regulations and/or local policy. 
T-Tunnel Closure Report Section: Appendix D

Revision: 0

Date: August 2008

THIS PAGE INTENTIONALLY LEFT BLANK 


\section{APPENDIX E}

\section{FINAL FACILITY CLOSURE VERIFICATION SITE VISIT ATTENDANCE ROSTER}


T-Tunnel Closure Report Section: Appendix E

Revision: 0

Date: August 2008

THIS PAGE INTENTIONALLY LEFT BLANK 


\section{ATTENDANCE LIST \\ N-and T-TUNNELS WALKDOWN \\ FEBRUARY 8, 2007}

Nevada Division of Environmental Protection:

Greg Raab

Mark McLane

Denny Nicodemus

SNJV:

Wayne Griffin

DTRA:

Barbara Harris-West

NSTec:

Gerald Chavez-Construction

Annette Primrose-ER

Dan Tobiason-ER

Tim Echelard-ER

Elaine Solzano-IH

Derek Hall-Ecological Services

Art Francis-Facilities

George Salyer-Facilities 
T-Tunnel Closure Report

Section: Appendix E

Revision: 0

Date: August 2008

\section{THIS PAGE INTENTIONALLY LEFT BLANK}

